\title{
Origin and phylogeny of the Cretaceous thoracican cirripede family Stramentidae
}

\author{
Andrew Scott Gale \\ School of Earth and Environmental Sciences, University of Portsmouth, \\ Burnaby Building, Burnaby Road, Portsmouth PO1 3QL, UK
}

A cladistic analysis of basal scalpellomorph cirripedes was undertaken in order to identify the phylogenetic position of the Stramentidae; this yielded a well-supported tree, in which the family is positioned crownwards of Archaeolepas, but basal to the families Scalpellidae and Zeugmatolepadidae. A new genus, Loriolepas, is described to accommodate some species previously referred to Archaeolepas. The basal scalpellomorphs display a remarkable change in shell mineralogy from calcium phosphate to calcium carbonate (Eolepas to Archaeolepas); the latter group is identified as a monophyletic clade, the Thoracicalcarea nov. A revised taxonomy of the predominantly Late Cretaceous cirripede family Stramentidae is presented. The Stramentidae are subdivided into two subfamilies, the Loriculinae nov., and the Stramentinae, based on characters of tergum, carinolatus and peduncular plates. The former subfamily includes Loriculina Dames, 1885, Metaloriculina gen. nov. and, doubtfully, Blastolepas Drushchits and Zevina, 1969, and three new species are described, Loriculina ifrimae, Metaloriculina stramentioides and Metaloriculina norvicensis. The Stramentinae include Leweslepas gen. nov., Stramentum Logan, 1897 and Parastramentum gen. nov. New species are Leweslepas hattini, L. hauschkei, L. wrightorum, Parastramentum albertaensis, P. brydonei, P. peakei, Stramentum alekseevi and S. praecursor. Cladistic analysis of the Stramentidae, based on 25 characters, supports the monophyly of the family, but relationships between subfamilies and genera are poorly resolved. However, in north-west Europe there is an evolutionary morphocllne, straigraphically calibrated, from the early Cenomanian Leweslepas hauschkei gen. et sp. nov., through the middle Cenomanian Stramentum praecursor sp. nov. to the late Cenomanian- 
Turonian S. pulchellum. A split from this lineage is found in the Western Interior Basin of North America, and the early Turonian S. canadensis gave rise to the middle Turonian S. elegans, which lived epibenthically. Stramentum elegans gave rise to the new genus, Parastramentum.

Keywords: cirripedes; Cretaceous; Stramentidae; phylogeny

\section{Introduction}

Stramentids, comprising the genera Stramentum Logan, 1897 and Loriculina Dames, 1885, are a distinctive group of Cretaceous (predominantly Late Cretaceous) pedunculate cirripedes which are usually found attached to ammonite shells, or more rarely, to the benthic bivalve Inoceramus (Hattin \& Hirt 1991). Their rarity, distinctive shape and pleasing appearance has led to a fairly extensive literature which describes numerous species. The overall outline of these cirripedes is oval, they are laterally compressed, and possess a peduncle covered by eight columns of large, alternating and imbricating plates. The low capitulum is made up of twelve plates, including a carina, a rostrum, and paired scuta, terga, upper laterals and carinolaterals (Hattin 1977; Hattin \& Hirt 1991). The genus Stramentum is widely distributed, having been recorded from the Cenomanian to Campanian at localities in Canada (Whiteaves 1889), USA (Logan 1897; Withers 1945; Hattin 1977; Hattin \& Hirt 1991), Mexico (Vega et al. 2007; Ifrim et al. 2011), Columbia (Royo y Gomez 1941; Villamil and Arango 1998), Japan (Nomura et al. 2009), Nigeria (Collins 1986), Algeria (Davadie and Emberger 1955), the Czech Republic (Kočova Veselská et al. 2011, 2013), Germany (Hauschke1994; Hauschke et al. 2011; Jagt 2013), France (Breton \& Boiné 1993), the United Kingdom (Withers $1935)$ and Lebanon (Dames 1885). In contrast, Loriculina is very poorly known from two incomplete immature individuals, one from Lebanon (Dames 1878), the other from Germany (von Zittel 1885) and a small number of isolated plates referred to the genus are recorded from England, Germany and France (Withers 1935). 
The origin of the Stramentidae has been suggested to lie either in the Jurassic-Early Cretaceous genus Archaeolepas von Zittel,1885, or in Zeugmatolepas Withers, 1913 (Withers 1935). Some species of Archaeolepas evidently possessed a peduncle similar to that of stramentids, with eight columns of imbricating, interdigitating plates, but the capitulum is made up of only six plates (carina, rostrum, plus paired scuta and terga). In Zeugmatolepas, there are very many small rows of lateral plates, and the capitulum includes at least 34 valves. Withers (1935) was impressed by the similarity between Zeugmatolepas and Stramentum in the high positions of the carinolatus and upper latus, and suggested this as a possible origin of Stramentum, by reduction of valve numbers.

Articulated stramentids are usually rare fossils, preserved by rapid burial in oxic benthic environments and by ammonites settling post mortem on anoxic sea floors (Hauschke et al. 2011; Ifrim et al. 2011), or more rarely by overgrowth by the ammonite host (Drushchits \& Zevina 1969; Wittler 1996). However, in the Western Interior Basin of the USA, the Turonian species $S$. elegans Hattin,1977 lived attached mostly to benthic bivalves (Inoceramidae), more rarely to empty ammonite shells (Hattin \& Hirt 1991). However, isolated plates have proved to be common in residues of Late Cretaceous sediments, and provide important information, not accessible in the articulated specimens, which are usually crushed.

The present paper has two aims; firstly, to clarify relationships amongst basal scalpellomorphs in order to establish the likely phylogenetic position of the Stramentidae, and secondly, to describe the taxonomy and phylogeny of that family on the basis of extensive new material. The paper is one in a series redescribing Jurassic and Cretaceous thoracicans from the UK and elsewhere (Gale 2014a, b; Gale \& Sørensen 2014, 2015). This revision was initially stimulated by the discovery of new articulated stramentids from the Cenomanian Lower Chalk of Lewes, Sussex, as well as by subsequent important finds in the Coniacian of Mexico (Ifrim et al. 2011) and the upper Campanian Chalk of Norfolk, UK.

\section{Institutional abbreviations}


BM, Booth Museum, Brighton, UK; CPC, Museo del Desierto, Saltillo, Coahuila, Mexico; KU, University of Kansas; MHNH, Muséum d'Histoire Naturelle du Havre, France; NHMUK, Natural History Museum, UK; OUM, Oxford University Museum, UK; PIMUZ, Paläontologisches Institut und Museum, Universität Zürich, Switzerland; SM, Sedgwick Museum, Cambridge, UK.

\title{
Homology and terminology of scalpellomorph cirripede plates
}

\author{
Valve mineralogy \\ Although it has been generally thought that scalpellomorph barnacles have \\ always possessed a shell mineralogy of calcite (e.g., Newman et al. 1969), \\ Høeg et al. (1999) argued that the Late Triassic-Early Cretaceous genus \\ Eolepas, widely believed to be a basal scalpellomorph (Newman 1987; \\ Buckeridge \& Newman 2006) had a primary phosphatic composition and is \\ preserved as the mineral francolite. This was challenged by Buckeridge \& \\ Newman (2006), who suggested that the material was possibly either a \\ secondary replacement by calcium phosphate, or primary calcium
} hydroxylapatite, as reported from the primitive thoracican Ibla (Lowenstam et al. 1992; Lowenstam \& Weiner 1992). However, Reid et al. (2013) used solid state nuclear magnetic resonance to identify the composition of valves of $I b / a$ cumingi Darwin,1851 as a new, unique, poorly ordered hydrogen phosphatelike material, ${ }^{13} \mathrm{C}$ SSNMR.

Preliminary investigation of two well-preserved species of Eolepas ( $E$. rhaetica Moore, 1861 and E. bathonica Withers, 1928) and the Late Carboniferous Praelepas jaworskii Chernyshev, 1930, using an ion probe, confirms the presence of abundant phosphorus in valve mineralogy (Koči et al. 2015; Gale \& Schweigert in prep.). This has significance for the origin and basal evolution of scalpellomorphs, because Eolapas has been placed in the same family as Archaeolepas, the putative ancestor of the Stramentidae (Buckeridge 1983; Buckeridge \& Newman 2006). The valves of Archaeolepas, 
stramentids, calanticids and scalpellids are all made of calcite, as are all extant balanomorphs and scalpellomorphs (Chave 1954).

\section{Capitulum}

In the Ibliformes, only paired scuta and terga are present (Darwin 1851b;

Buckeridge \& Newman 2006; see Figs. 1E, 2A herein), but the Late Carboniferous Praelepas (Figs 1A, B, 2B herein) also possessed a carina. The Triassic-Early Cretaceous Eolepas has been reconstructed with a rostrum (Withers 1928, fig. 64) and this image has been reused (Newman et al. 1969; Buckeridge 1983). Høeg et al. (1999) claimed that Eolepas lacked a rostrum, but without supporting evidence or illustration. In my view, supported by Buckeridge \& Newman (2006) and Dr Günter Schweigert (pers. comm., July 2014), a rostrum was present, and this can be seen in an articulated individual of $E$. aalenensis (Richardson, 1908) from the Bajocian of Switzerland (Schweigert 2014; refigured here, Fig. 1C). This specimen, and another individual from the Bathonian of Normandy (Fig. 1D), are used to make a new reconstruction of Eolepas (Fig. 2C).

In the Ibliformes, the shape of the scuta and terga is triangular (Buckeridge \& Newman 2006, fig. 2), but the former are tall and narrow in Ibla, but relatively broad in Neoibla, Idioibla, Chaetolepas and Chitinolepas. The umbo is apical to subapical, and primordial valves on both the tergum and scutum were described in Idioibla pygmaea (Broch, 1922); such are visible on species of Chaetolepas and Chitinolepas. Terga in Ibla are tall, triangular and incurved towards the scutum (Fig. 1E), but in the other genera, the nearly straight scutal/tergal boundary is inclined ventrally, and a low, triangular tergum, with a convex occludent margin, sits like a cap above the scutum (e.g., Idioibla, Fig. 2A here).

In Praelepas, the tergum is similar in shape and position to that in Idioibla (Fig. 1 A, B) but the scutum is pentagonal with a subcentral umbo. The triangular, concavo-convex carina contacts the carinal margin of the scutum, and the base of the occludent margin of the tergum (Figs. 1A, B, 2B). In Eolepas, the carina is similar to that in Praelepas, but the tergum is tall and rhombic, with a well-marked apicobasal ridge. The scuta of Eolepas are taller than broad, triangular and the occludent margin is gently convex. The carina 
contacts only the tergum, along the long carinal margin and a low, triangular rostrum is present (Fig. 1C).

The capitulum of calcitic scalpellomorphs always includes paired scuta and terga, a rostrum and a carina (Darwin 1851b; Newman et al. 1969; see Fig. 2D-F). The terga are typically rhombic, with an acute basal angle and are very similar to those of Eolepas, but in Stramentum the tergum is triangular (Fig. 2E). In Archaeolepas, Loriolepas gen. nov. and Bosquetlepas Gale, in Gale \& Sørensen, 2015, the terga have a short, straight basal margin. The scuta are typically triangular, taller than broad, with an apical umbo (Fig. 1D, E), but in Stramentum the scuta are trapezoidal with a subapical umbo (Hattin 1977; Fig.1E here). The carina in Archaeolepas, Loriolepas gen. nov. and Bosquetlepas is triangular, taller than broad and variably concavo-convex. It is narrow, tall and flat in Stramentum (Hattin 1977). Scalpellid carinae are morphologically more complex, with differentiated parietes, intraparietes and a flat to convex tectum (Withers 1935). The carina contacts the tergum alone in Archaeolepas and Loriolepas gen. nov. (Figs. 1, 3, 4), but in Stramentum it contacts only the carinolatus (Fig. 1E), and in scalpellids it contacts the carinolatus, upper latus and the tergum (Fig. 1F).

Archaeolepas (Fig. 3), Loriolepas gen. nov. (Fig. 4) and Bosquetlepas completely lack lateral plates, but in Stramentum a triangular upper latus sits between the carina and tergum, and a carinolatus is present between the tergum and carina (Fig. 1E). The lower margins of these plates, with the exception of the tergum, contact peduncular plate columns (see below). In scalpellids, the pattern of lateral plates is highly distinctive and very consistent, including an upper latus, a carinolatus, and a rostrolatus, which alternate with the capitular plates, and a lower inframedian latus, set beneath the upper latus and between the carino- and rostrolatus (Newman et al. 1969; Fig. 2F here). In pollicipedids, zeugmatolepadids and calanticids, lower whorls of lateral plates are also present, often including a subcarina, a subrostrum, and other unnamed plates. The ontogenetic sequence of introduction of the lateral plates was illustrated in Pollicipes by Broch (1922).

It has long been considered likely that the lateral plates of scalpellomorphs originated by upward transfer of peduncular plates from the top of respective columns (Darwin 1851b; Newman 1987), and this seems 
probable, even if it is virtually untestable. It can be argued that the upper latus was the first lateral plate to be acquired, as it is the only plate retained after secondary loss of the other laterals in forms such as Neolepadidae (e.g., Newman 1979); it is triangular, covers the junction between the scutum and tergum and presumably affords valuable protection to this contact.

Terminology of the capitular valves of the Stramentidae was discussed and summarised by Hattin (1977, fig. 2), and his nomenclature is largely followed here (Fig. 8). However, a few modifications are considered necessary; Hattin used the term 'rostral slip' for the depressed rostral surface of the scutum with which the inner lateral margin of the rostrum articulates in Stramentum elegans, in allusion to Darwin's (1851a) use of 'tergal slip' for the reduced surface of the scutum in species of Brachylepas (Gale \& Sørensen 2014). The term rostral articulation surface is preferred here. The development of this surface varies from a poorly defined depressed area, to a discrete, sharply defined, slightly inset area in Parastramentum gen. nov.

\section{Peduncle}

Primitively, thoracicans lack peduncular plates, and these are absent in Ibla, Praelepas and Eolepas (Withers 1928; Newman et al. 1969; Buckeridge \& Newman 2006; see Fig. 2A-C). The peduncle of extant scalpellomorph cirripedes is made up of columns of plates which form at the boundary between the peduncle and capitulum, usually after the full compliment of capitular plates have been added (Newman \& Ross 1998; Young 2001). This is true in all taxa which have been studied, with the exception of the scalpellid Scalpellopsis (Young 2001) in which peduncular plates are added before the final laterals. Thus, the youngest plates are usually found at the contact with the capitulum. The plates in scalpellids are added alternately in two series, scI-sr, and rl-cl, which correspond with the eponymous capitular plates. Plesiomorphically, eight columns of plates are present (Newman \& Ross 1998; Young 2001), but some scalpellids have reduced the number, and calanticids and pollicipedids have generated a very large number of small plate rows (Young 2001). The peduncle of the Late Mesozoic Stramentidae is covered by eight columns of large, robust plates, which are broader than tall, 
and the columns usually alternate and rarely abut, and thus conform with the presumed plesiomorphic condition.

In the type species of Archaeolepas, A. redtenbacheri (von Zittel, 1885), eight columns of peduncular plates have also been identified, and reconstructions of the genus have followed Withers's original interpretation (1928, fig. 64; see also Newman et al. 1969; Buckeridge 1983). However, a re-examination of the original material of $A$. redtenbacheri has shown that ten columns were present (Fig. 3), and in other species previously referred to Archaeolepas numerous columns are seen (Fig. 4). Therefore, it is necessary to discuss the homology of peduncular plate columns in basal scalpellomorph evolution, and the likely transitions to the condition in more derived scalpellids and calanticids.

In A. redtenbacheri (Fig. 3) the peduncle is made up of ten columns of alternating plates, which comprise two carinal columns (c1, c2), one which contacts the base of the tergum (t), two columns which contact the basal margin of the scutum (s1, s2), and a rostral column (r). The plates of the $s 1$, $s 2$, $t$ and c2 columns are crescentic with a flat to slightly concave basal margin and a rounded upper margin; they are two to three times broader than tall, interdigitate internally and imbricate strongly (Fig. 3), such that only the upper portion is usually visible on the exterior. The general arrangement and shape of the plates is similar to that in stramentids which, however, only ever have eight columns (Hattin 1977).

The evolution of lateral plates evidently necessitated significant changes in the position and relative size of the peduncular plate columns. The evolution of the upper latus as a cover over the scutal-tergal junction would only be effective if there was a sideways shift in the relative positions and widths of the peduncular columns, permitting the newly formed upper latus to articulate closely with, and partially overlie, both the scutum and tergum (see above). This brings the $u$ l column (formerly $t$ ) to a central position on the side of the peduncle, where it is positioned in later scalpellomorphs. Formation of the carinolatus was accompanied by a similar lateral shift in the c 2 column, such that it sat directly beneath the carinolatus. The loss of one scutal column, probably s2, left a single peduncular column directly beneath the scutum in 
stramentids. Finally, and at a later stage, the evolution of the rostrolatus resulted in the transfer of the scutal column to the rostrolatus $(\mathrm{rl})$.

Homologies between $A$. redtenbacheri and stramentids can be identified as;

1) the $c 1$ and $r$ columns are the same

2) the c2 column has evidently transferred to the carinolatus (cl)

3) the t column has transferred to the upper latus (ul)

4 ) one of the two scutal columns has been lost.

The transition to the plesiomorphic scalpellid condition, and the terminology of Newman \& Ross (1998) involves transfer of the scutal column to the rostrolatus (rl) and development of an inframedian latus (Fig. 2F).

\section{Cladistic analysis of basal scalpellomorphs and stramentid relationships}

\section{Polarity determination}

There is a consensus which extends back to the work of Withers (1928) that a number of features of Eolepas, Archaeolepas and stramentids are plesiomorphic among scalpellomorphs, most notably the small number of capitular plates (Archaeolepas, Eolepas, 6; carina, rostrum, 2 scuta, 2 terga; stramentids, 10; with upper laterals and carinolaterals) and the robust 8 columns of peduncular plates found in Archaeolepas and stramentids (Newman \& Ross 1998; Young 2001). Indeed, most evolutionary scenarios place Eolepas at the base of the scalpellomorphs, and trace its origin back to the five-plated Carboniferous Praelepas (see Newman 1979, 1987; Fig. 5 herein), usually interpreted as a lepadomorph. The progressive acquisition of additional capitular plates (upper laterals, carinolaterals, rostrolaterals, subrostra, subcarinae) is then interpreted as progressive evolution towards more derived scalpellomorphs (Fig. 5). The discovery of living cirripedes in which the capitulum consists of only 8 plates ( 2 scuta, 2 terga, carina, rostrum + two upper latera) was interpreted as evidence of 'living fossils' (Newman 
1979). Neolepas and the three additional, closely related, genera which comprise the Neolepadinae are all found associated with hydrothermal vents - a source of supposed Mesozoic relicts (Newman 1979; Yamaguchi et al. 2004).

In the ontogeny of the scalpellomorph Pollicipes (Broch 1922), the primordial five plates (2 scuta, 2 terga, carina) form first, then, successively, the rostrum, the upper laterals, and later the carinolaterals, rostrolaterals and subrostrum (Fig. 5). Paedomorphic evolution at various stages of this ontogenetic sequence could produce, for example, a lepadomorph morphology ( 5 plates; 2 scuta, 2 terga, 1 carina), or a neolepadine ( 8 plates; rostrum, carina, 2 terga, 2 scuta, 2 upper latera). Newman's (1979, fig. 5; 1987) model of thoracican evolution identified a succession of living and fossil taxa as corresponding to individual ontogenetic stages of Pollicipes (Fig. 5). Thus, the ontogeny of Pollicipes has been interpeted as recapitulating phylogeny.

However, this rather neat scenario presents a number of problems. The first of these is the possibility that recurring paedomorphic evolution has produced apparently plesiomorphic taxa, as has been widely demonstrated in diverse animal phyla (McNamara 1995). Because all scalpellomorphs appear to undergo a basically similar ontogeny, the likelihood that superficially plesiomorphic forms have repeatedly evolved is strong. A problem with cirripedes is that the rather simple morphological structures do not readily permit cladistic testing of possible paedomorphic derivation, as can be achieved in vertebrates, for example.

The widely accepted model of thoracian cirripede evolution (Fig. 5) was challenged by the publication of the first substantial molecular phylogeny of the group (Pérez-Losada et al. 2008). In this, calanticids appear as basal to the scalpellomorph radiation, and lepadomorphs appear as sister group to the bulk of the group, plus some supposed verrucomorphs (Neoverruca). Lithotryids and pollicipedids are sister group to the balanomorphs plus the verrucomorphs. Although there are some significant conflicts with the fossil record, the fundamental message of the molecular analysis is that it is probably incorrect to follow simplistic morphological scenarios of thoracian cirripede evolution strictly. Additionally, the molecular tree supports at least 
two paedomorphic pathways, the derived positions of the apparently plesiomorphic Neolepadinae and Lepadomorpha. Two hypotheses are proposed to test the position of basal scalpellomorphs.

Hypothesis 1. Archaeolepas is a basal calcareous thoracican, which shows the plesiomorphic condition of a six-plated capitulum and ten columns of peduncular scales. Stramentids represent an offshoot from the main thoracican tree which develops the plesiomorphic eight-plated peduncle, but at a stage at which the upper latus and carinolatus had evolved, but prior to the rostrolatus.

Hypothesis 2. The condition in Archaeolepas and stramentids represents a secondary reversal, or two independent reversals, characterised by the loss of one lateral plate (stramentids) and all laterals (Archaeolepas), and a reduction of peduncular plate columns to eight, presumably from a more derived scalpellomorph.

There are a number of ways of testing the alternatives, both of which are superficially quite plausible, and suggested long ago by Withers (1928). Witness the peduncular plate reduction common in diverse scalpellids (Young 2001), which can reduce from eight columns to two (Newman \& Ross 1998), and the loss of all lateral plates except the upper latus in Neolepadidae and Neoverruca.

Test 1. There appears to be something fundamental about the eight-plated arrangement of peduncular scales in scalpellomorphs, because the $\mathrm{cl-I}-\mathrm{rl}$, and c-r columns match precisely the capitular plates which give them their names in eight plated forms. The plates are also introduced in a consistent order (Newman \& Ross 1998). Only exceptionally is there any further reduction. In a detailed review of peduncular plates, the eight column condition was interpreted by Young (2001) as plesiomorphic for the scalpellomorphs.

Test 2. The stratigraphical order in which successive taxa and morphological innovations appear provides a test for phylogenetic hypotheses (Smith 1994). 
Archaeolepas first occurred in the Callovian (Withers 1928), and continued into the Tithonian Stage. The relatively derived zeugmatolepadids (according to Hypothesis 1) appear slightly earlier, in the Bathonian (Withers 1928; 168 Ma). The stramentids appear significantly later, in the late Aptian (c. $125 \mathrm{Ma}$ ). There appears to be little stratigraphical support for either hypothesis; however, the Mesozoic fossil record of thoracicans can be seen as very incomplete and patchy; a diversity of scalpellids appear contemporaneously in the Aptian (Arcoscalpellum, Virgiscalpellum) and must have had a significantly older radiation unrepresented by any fossil record. Cretiscalpellum, which is generally regarded as a calanticid, but can be regarded as sister taxon basal to the Scalpellidae, appears in the Tithonian (Gale 2014a).

Test 3. The secondary reductions in capitular and peduncular plates seen in derived scalpellomorphs are not inherently associated. Thus, neolepadids lose all laterals except the upper latus, but retain numerous and irregular columns of small peduncular plates. In contrast, scalpellids reduce the number of peduncular columns, but usually retain a full complement of lateral plates (Young 2001). The condition in Archaeolepas and stramentids, in which both laterals and peduncular columns are reduced, can therefore be reasonably interpreted as plesiomorphic. The consensus would therefore appear to support Hypothesis 1, and the polarity of characters in the list (Table 1 ) is determined accordingly.

\section{Basal scalpellomorph relationships}

A single tree (Fig. 5) was recovered from heuristic, unconstrained analysis (stepwise additions option random, branch swapping option TBR) of twelve characters in Ibla, Idioibla, Praelepas, Eolepas, Archaeolepas, Stramentum, Arcoscalpellum and Zeugmatolepas.

1) There is stepwise introduction of characters within basal thoracicans, in a stratigraphical order which matches the cladogram (except Ibla). Thus, Praelepas (Late Carboniferous) is the most basal taxon with five primordial plates and a carina; Eolepas (Triassic) acquired a rostrum, 
rhomboidal terga and a concavo-convex triangular scuta, and thus resembles later scalpellomorphs. Finally, Archaeolepas (mid-Jurassic) developed peduncular plates, and Stramentum (Cretaceous) acquired an upper latus and a carinolatus.

2) An abrupt change takes place in plate chemistry from forms with a phosphatic composition (Ibla, Praelepas, Eolepas) to those with a calcareous one (Archaeolepas, Stramentum, scalpellids). Høeg et al. (1999) considered that such a change was so improbable that they excluded the possibility from their cladistic analysis. However, as pointed out by Buckeridge \& Newman (2006), there is no doubt that Eolepas is morphologically similar to scalpelliforms, as confirmed here. The possibility that Eolepas independently evolved this morphology cannot be ruled out entirely, but if this were the case, we have no fossil evidence for the ancestry of calcite-shelled pedunculate thoracicans, which would be surprising, given the high preservation potential of their plates.

3) The phylogenetic analysis is only partly complete, because the study omitted numerous scalpellomorphs including the calanticids, which also possess extra lateral plates and have been shown by molecular analysis to be sister group to the scalpellids (Pérez-Losada et al. 2008) and thus are part of the story. It appears that scalpellomorphs went through a stage in the Jurassic represented by the zeugmatolepadids, in which they evolved numerous lateral plates, which were secondarily lost in the lineage leading to the scalpellids, but retained in the pollicipedids. Confirmation of this will require considerable additional work beyond the scope of the present study.

\section{Cladistic analysis of the Stramentidae}

A character set of 25 (see Supplementary materials) was analysed using PAUP (heuristic unconstrained analysis, stepwise additions option random, branch swapping optio TBR) and a single consensus tree was generated (Fig. 
7), using Archaeolepas and Eolepas as outgroups. The Stramentidae form a well-supported clade (100\% bootstrap), but within this the relationships between Loriculinae (74\%, Metaloriculina gen. nov., Loriculina), Leweslepas gen. nov., Angulotergum, S. pulchellum and Parastramentum gen. nov. + S. elegans (89\%) are not resolved and form a polytomy. This is caused by numerous character reversals and parallels within the Stramentidae, such as in the position of the scutal umbo. This character has changed from an apical to a subapical position perhaps three times in the phylogeny of the group.

\section{Palaeobiology of stramentids}

The first stramentid ever described (Fig. 16B) was attached to an ammonite (G.B. Sowerby Jr 1843; Darwin 1851a) and ever since then stramentids have most often been found attached to the shells of ammonites (e.g., Collins 1986; Ifrim et al. 2011). Preservation of stramentids by ammonite bioimmuration (overgrowth) has been recorded from the Aptian of the Caucasus (Drushchits \& Zevina 1969) and the Turonian of Germany (Wittler 1996), unequivocal evidence for in-life attachment. The attachment of a Stramentum to the orthoconic baculitid ammonite Sciponoceras, and the orientation of its occludent margin towards the apertural end of the shell, was used by Hauschke et al. (2011) as evidence of the horizontal life orientation of those ammonites. Material figured here from the Santonian Niobrara Chalk of Kansas shows abundant Stramentum attached to the flanks of large baculitid ammonites (see below), although it is not possible to be certain that this happened during life.

However, Stramentum elegans Hattin, 1977 from the middle Turonian Fairport Member of Kansas was exclusively benthic in habitat, attaching most commonly to large, living inoceramid bivalves, more rarely to other epizoans on these shells, and very rarely to ammonite shells lying on the sea floor (Hattin \& Hirt 1991). Without evidence from bioimmuration, it is not possible to tell whether attachment took place in life, onto dead, floating shells or on to sunken shells on the seafloor. 


\title{
Systematic palaeontology
}

\author{
Superorder Thoracica Darwin, 1851b
}

Order Scalpelliformes Buckeridge \& Newman, 2006

Remarks. The group is technically paraphyletic, because it does not include the common ancestor and all descendants, which must include the Sessilia (Gale 2014b; Gale \& Sørensen 2014), but it is useful and therefore retained here.

Family Eolepadidae Buckeridge, 1983

Originally established by Buckeridge (1983) as a subfamily of the Scalpellidae, it comprised the fossil genera Eolepas Withers, 1928 and Archaeolepas von Zittel, 1885, and the living genus Neolepas Newman, 1979. Subsequently, Buckeridge \& Newman (2006) elevated Neolepadidae to family status, and divided it into the Eolepadinae (Archaeolepas, Eolepas) and Neolepadinae Yamaguchi, Newman \& Hashimoto, 2004.

There are a number of problems with this classification. Firstly, Høeg et al. (1999) claimed that the valves of Eolepas were made of calcium phosphate (confirmed here; see above), and more contentiously, proposed that the genus lacked a rostrum. They therefore placed Eolepas in a separate clade, basal to all other thoracicans, together with Ibla. Buckeridge \& Newman (2006) challenged both issues, suggesting that the valves of Eolepas might not be completely phosphatic, or were secondarily phosphatised, and that a rostrum was in fact present. On this basis they left the family in the Scalpelliformes.

Pérez-Losada et al. (2008) demonstrated on the basis of molecular phylogeny that neolepadids (Neolepas, Ashinkailepas, Leucolepas, Volcanolepas) were sister group to Neoverruca spp., which in turn is sister group to the Scalpellidae. Gale (2014b) confirmed the close relationship 
between the Neolepadidae and Neoverruca from morphological evidence. This effectively removes the clade from the ancestry of the scalpellomorphs, and falsifies the hypothesis that Neolepas represents a transitional form between Archaeolepas, which lacks lateral plates, and later scalpellomorphs which have a full compliment of laterals (Newman 1979).

In conclusion, the Eolepadidae is considered to be paraphyletic, including as it does both taxa which can be considered morphologically to be sister group to the scalpellomorphs (Eolepas), but which possess a phosphatic skeleton, and those which represent basal, calcareous scalpellomorphs, such as Archaeolepas, which have a calcitic composition and peduncular plates. Therefore, only Eolepas is retained in the Eolepadidae.

\section{Clade Thoracicalcarea nov.}

Diagnosis. Thoracica in which the shell plates are composed of calcite.

Remarks. The mineralogical change from phosphate to carbonate which took place between Eolepas and Archaeolepas (Fig. 6) is a fundamental event in the history of the Thoracica, and marks the base of a monophyletic clade including all scalpellomorphs except Eolepas, plus Sessilia. The hierarchical position of this clade within the broad classification must await further study.

Genus Archaeolepas von Zittel, 1885

Amended diagnosis. Calcareous scalpellomorphs which lack lateral plates and have a peduncle consisting of 14 columns of nearly even breadth, composed of strongly imbricating plates. Peduncle and capitulum of approximately even height, carina less than half the height of tergum. Tergum and scutum smooth, convex.

Type species. Pollicipes redtenbacheri Oppel, 1862, by subsequent designation of Withers (1928, p.83). Tithonian, Germany. 
Referred species. Pollicipes royeri de Loriol, in de Loriol, Roger \& Tombeck,1872, from the Kimmeridgian of Haute Marne, France.

Remarks. The original material of Oppel (1862) and von Zittel (1885) is refigured here (Fig. 3A-D), and provides little information to further the descriptions of Withers (1928). However, there is now more material available in private collections from the Tithonian plattenkalk of southern Germany, which will provide the basis for eventual redescription of the species. Archaeolepas can be readily distinguished from Loriolepas gen. nov. by the robust form of the peduncle, with 10 columns of large plates, whereas the new genus has more than 20 columns of much smaller plates. Additionally, the low capitulum and carina which is less than half the height of the tergum are distinctive.

\section{Genus Loriolepas gen. nov.}

Type species. Pollicipes suprajurensis de Loriol, in de Loriol \& Pellat, 1867.

Diagnosis. Scalpelliforms which lack lateral plates, and possess a capitulum which is less than half the height of the peduncle. Peduncular plates small, polygonal, set in $20+$ columns. Carina two-thirds the height of tergum, strongly incurved towards tergum. Tergum possesses sharply demarcated, flat-topped apicobasal ridge which forms a basal margin.

Derivation of name. For the great Swiss palaeontologist and zoologist, Perceval de Loriol (1828-1908).

Included species. Archaeolepas decora Harbort, 1905, from the Valanginian of Musingen, Bückeburg, Germany (Fig. 4B, C, F, G). ? Pollicipes planulatus Morris, 1845.

Remarks. Loriolepas gen. nov. differs significantly from Archaeolepas, from which it presumably descended, in the smaller peduncular plates set in more numerous columns (Fig. 4B), the tall incurved carina and the presence of 
apicobasal ridges on terga and scuta (Fig. 4D-G). The new genus gave rise to the distinctive Late Cretaceous family Myolepadidae Gale, in Gale \& Sørensen, 2015, characterised by the presence of rostro- and tergoscutal depressor muscles, and locally abundant in near-shore Late Cretaceous environments (Gale \& Sørensen 2015).

Family Stramentidae Withers, 1920

Diagnosis. Oval, laterally compressed calcareous thoracicans which possess a carinolatus, an upper latus and a peduncle which is covered by 8 columns of strongly imbricating plates.

Remarks. The monophyly of the family is strongly supported by the cladistic analysis (Fig. 6). The terminology used here follows Hattin 1977 (Fig. 8). It should be noted that the term rostral slip is replaced by rostral articulation surface, and that a numerical value is used for the position of the scutal umbo, with (e.g.) an apical position designated 0/10, a central one 5/10 and a basal position 10/10. The concept of capitular angle is introduced here, which is the angle subtended by the axis of the middle peduncular column (upper latus column) to the base of the capitulum. Thus, Leweslepas gen. nov., in which the boundary between the capltulum and peduncle is transverse, has a low capitular angle $\left(95-100^{\circ}\right)$, whereas species such as Stramentum pulchellum and S. inconstans, in which the boundary slants, have high capitular angles $\left(110-125^{\circ}\right)$.

\section{Subfamily Loriculinae nov.}

Diagnosis. Stramentids in which the carinolatus and tergum are arranged transversely, and their contact is subparallel to acutely angled; tergum broad, flat, rectangular to subtriangular in outline; contact between peduncular plates of carinolatus and upper latus columns flat, with no interdigitation. Plates of rostral column of peduncle $\mathrm{V}$-shaped, with inner median vertical groove. 
Included genera. Loriculina Dames, 1885, Metaloriculina gen. nov., and, questionably, Blastolepas Drushchits \& Zevina, 1969.

Remarks. The discovery of complete articulated specimens of Loriculina ifrimae sp. nov. and Metaloriculina stramentoides gen. et sp. nov. (Figs 9, 10, 12) in the Coniacian of Mexico, and abundant isolated valves of Metaloriculina norvicensis gen. et sp. nov. from the upper Campanian chalk of Norfolk, UK, permits definition and detailed description of the subfamily. The most distinctive features are the transversely arranged tergum and carinolatus, the rectangular to subtriangular tergum, and the flat contact between peduncular plates of the carinolatus and upper latus columns (Fig. 9). Metaloriculina gen. nov., also from the Coniacian of Mexico, shares these characters, but also posesses a centrally positioned scutal umbo. The position of this feature has been previously used to separate Loriculina (apical) and Stramentum (subapical; see Withers 1935; Hattin 1977; Hauschke 1994). Furthermore, the discovery of articulated stramentids in the Cenomanian of the UK which possess an apical scutal umbo, but are otherwise similar to Stramentum (e.g., acutely angled carinolatus-tergum contact, strongly interdigitating carinolatusupper latus peduncular plates) necessitates change to the definition of the genus Loriculina. A simple solution, adopted here, is to divide the Stramentidae into two subfamilies, the Loriculinae nov. and Stramentinae, on the basis of these consistent characters. The development of a subapical umbo probably occurred three times in the evolution of the Stramentidae.

A further interesting discovery is that the peduncular plates of the rostral column of Metaloriculina norvicensis gen. et sp. nov., from the upper Campanian of Norfolk, UK, are highly distinctive; they are V-shaped, and on the interior possess an apicobasal median groove which presumably carried a soft structure such as a ligament in life (Figs 11, 13). Similar plates are visible in the holotype of Loriculina ifrimae sp. nov. andthe presence of these plates adds to the unique morphology of the Loriculinae.

The new material of Metaloriculina norvicensis gen. et sp. nov. and Parastramentum peakei gen. et sp. nov. from the upper Campanian of Norfolk provides additional information about peduncular construction of stramentids. Although articulated individuals of stramentids are a major source of 
morphological information, they are almost invariably flattened laterally, and it is not usually possible to see details of the articulation of plates (Hattin 1977). The isolated plates can be readily assigned to both taxa, and to individual plate columns, with reference to articulated material. Thus, they provide information about articulation patterns, and because the plates are three dimensional, allow accurate reconstruction of the cross-sectional shape of stramentids for the first time. Metaloriculina gen. nov. possessed processes for articulation on the upper latus column, inserting under the carinolateral and scutal columns, respectively, absent in Parastramentum gen. nov. and Stramentum (Fig. 11). Additionally, the material demonstrates that the rostral side of the peduncle cross-section in Metaloriculina gen. nov. was much broader than the carinal side, with strongly convex plates of the scutal column (see the description of $M$. norvicensis gen. et sp. nov. below, for details). In contrast, Parastramentum gen. nov. was symmetrically oval in cross section (Fig. 27).

Blastolepas is provisionally referred to the Loriculinae nov., on the basis of the oblique contact between the carinolatus and the tergum.

Genus Blastolepas Drushchits \& Zevina, 1969

Type species. Blastolepas orlovi Drushchits \& Zevina, 1969; upper Aptian, Caucasus.

Discussion. The drawings of the species provided by Drushchits \& Zevina (1969) are curious in a number of ways, probably because of the poor preservation of the material which made interpretation difficult. However, the highly irregular arrangement of the peduncular plates (Drushchits \& Zevina, 1969, fig. 2) is not supported by the photographs (e.g., their pl. 11, fig. 16) which show a regular arrangement of eight columns as in Stramentidae. An equilaterally triangular upper latus is clearly present (their pl. 11, figs. 3, 6, 16), and a transversely elongated carinolatus sits beneath the tergum. The scutum has a convex occludent margin (their pl. 11, fig. 16), and I suspect that the 'subcarina' is a displaced plate from the carinal column. The reconstruction provided here (Fig. 9D) is admittedly based on very limited evidence, but it 
interestingly shows a number of features in common with the new reconstruction of Loriculina (see below).

Blastolepas is provisionally interpreted as a stramentid in which there is a small rostrum, and the scutum has a convex occludent margin. The upper latus is symmetrically triangular, but the carinolatus is broad and low, tapering towards the upper latus. The tergum is rhombic, relatively tall and contacts both the upper latus and the scutum on its scutal margin. A tall carina contacts both the carinolatus and the tergum.

The general construction of the capitulum is similar to that in Loriculina ifrimae sp. nov. (see below); the shape and size of the rostrum and scutum, the transverse form of the carinolatus, with a long near-horizontal contact with the tergum, the contact between the carinolatus, tergum and upper latus and the tall carina which articulates both with the carinolatus and tergum.

Differences are the attitude of the capitulum to the axis of the peduncle, which is about $90^{\circ}$, and this is reflected in the symmetry of the upper latus in $B$. orlovi. In Loriculina, the base of the capitulum is slanted at $50-60^{\circ}$ to the axis of the peduncle, and the upper latus is asymmetrical. The tergum is very different; it is rhombic and tall in B. orlovi, but low, rectangular and transversely elongate in $L$. ifrimae sp. nov.

The tall tergum is reminiscent of the condition in Archaeolepas, and can thus be interpreted as plesiomorphic with respect to the derived state in Loriculina. Blastolepas is therefore identified as the most basal stramentid, which provides important clues to both the origin of the family, and the evolution of lateral plates in scalpellomorphs (see above).

The broad, low carinolatus in Blastolepas resembles a peduncular plate in form, and it seems feasible that this is how the plate originally evolved, by transfer of the uppermost plate of the (originally) tergal column of peduncular plates into the capitulum; the peduncular column then became the carinolatus column of all subsequent scalpellomorphs (see Young 2001). The highly derived stramentids probably separated from the mainstream of scalpellomorph evolution shortly after the carinolatus had formed, and the low, transverse form of the carinolatus in Blastolepas and Loriculina retains the plesiomorphic condition. The origin of the stramentids thus predated the evolution of a rostrolatus, presumably by an equivalent plate transfer from the 
peduncle. This stage of evolution is unfortunately not yet represented by fossil material.

\section{Genus Loriculina Dames, 1885}

Type species. Loriculina noetlingi Dames, 1885, by subsequent designation of Withers (1935, p. 303).

Diagnosis. Loriculinae in which the scutal umbo is apical in position; the scutum is tall, triangular, and inclined towards the tergum; the scutum is thin, and lacks an internal shelf above the scutal adductor; the occludent margin is gently convex, and has a narrow, depressed margin; the margin in contact with the upper latus is strongly concave.

Age. Late Turonian-early Campanian.

Discussion. Until very recently, Loriculina was a rare and somewhat enigmatic genus, the understanding of which was based largely on two, small, incomplete individuals - the types of $L$. noetlingi from the upper Santonian of Lebanon (Dames 1885) and L. laevissima (von Zittel,1885) from the lower Campanian of Westphalia, Germany. Withers (1935) referred isolated valves from the Turonian to Campanian of the UK to the latter species, and also placed Loricula acuminata Darwin,1851a in Loriculina. This species is known only from an isolated scutum, probably from the Cenomanian of Stoke Ferry, Norfolk, and subsequently lost (Withers 1935).

The types of $L$. laevissima and $L$. noetlingi are both well preserved on the scutal-rostral side, but the carinolatus and tergum are incomplete, and the carina is completely missing (Fig. 9B, C, F). Withers, in his major revision of 1935, did not describe either the tergum or carinolatus in these type specimens, although he somehow identified isolated valves from the English Chalk as terga of $L$. laevissima (his pl. 40, figs. 8, 9, 12, 13). A cast of reasonable quality of the type of $L$. laevissima in the NHMUK collections is refigured here (Fig. 9B), and shows clearly that the tergum is transversely quite broad, and is situated above the carinolatus; they have a straight contact, 
subparallel with the cl column of peduncular scales, reminiscent of Blastolepas (Fig. 9D, see above) and quite different from the condition in Stramentum. The situation is similar in the type of $L$. noetlingi, but only scraps of the tergum and carinolatus remain. However, the shape and orientation of the carinolatus and tergum remained unknown, as did the carina, making Withers's identification of isolated terga appear to be rather ambitious.

Description. The complete form of Loriculina is now known from numerous specimens from the lower Coniacian of Mexico, here described as $L$. ifrimae sp.nov. (Figs. 9A, 10). These were figured by Ifrim et al. (2011, fig. 5/5, 6) as Stramentum pulchellum, but the specimens have apical scutal umbones and the same transversely oriented junction between the carinolatus and overlying tergum as seen in the type of $L$. laevissima, and can be therefore placed confidently in Loriculina. The carinolatus is triangular, with a squarely truncated contact with the upper latus. It has a long contact with the carina, and the umbo contacts both the carina and tergum. The tergum is rectangular and oriented transversely, such that the slightly prominent umbo contacts the tip of the carina; the growth lines are set at $90^{\circ}$ to the contact between the tergum and carinolatus. In addition to its apical scutal umbones, Loriculina also has a very different transversely arranged carinolatus and tergum, and a most unusual rectangular tergum, on which the growth lines diverge from the carinolateral margin, then inflect upwards at right angles, to run parallel with the upper lateral margin on the upper portion of the plate (Fig. 10A, B). A further notable feature of Loriculina is that the scutum is thin and delicately constructed, and the occludent margin of the scutum has a narrow, depressed margin. This is well seen in the types of $L$. laevissima and $L$. noetlingi, and in the fragmentary scuta from the Turonian of Froxfield, Hampshire, UK, figured by Withers (1935, pl. 40, figs. 6, 7) as L. laevissima. Furthermore, the interior of the scutum lacks a shelf above the scutal adductor scar (Fig. 10D).

Remarks. Withers (1935) thought that the two known articulated specimens of Loriculina were young individuals, presumably because the terga he identified as belonging to the genus from the English Chalk were large. The 
new material from Mexico is also small, and to date the genus is not known to have exceeded a maximum height of $2 \mathrm{~cm}$.

The new description of the morphology of Loriculina makes it possible to re-assess the isolated valves referred to the genus by Withers (1935, pl. 40), with the following conclusions:

1) The robust scuta with apical umbones and a shelf above the adductor scar which Withers referred to L. acuminata (pl. 40, fig. 1; after Darwin, 1851a, pl. 3, fig. 6a, b) and L. laevissima (pl. 40, figs. 3-5) are quite unlike the delicate scuta of Loriculina, and also lack the depressed occludent margin of that genus. They are placed in the stramentine genus Leweslepas gen. nov., which has apical scutal umbones, and a robust construction.

2) The delicate scuta from the Turonian chalk of 'Alton' (actually from Brydone's (1912) pit no. 125 at Froxfield, Hampshire), identified as $L$. laevissima by Withers (1935) are correctly referred to Loriculina. The specific identification appears to be uncertain, and they are here identified as Loriculina sp. The valves figured as terga (Withers 1935, pl. 40, figs. 8, 9) are terga of Parastramentum gen. nov. (see below).

3) The large triangular concavo-convex valves from the lower Campanian Chalk of East Harnham (Withers 1935, pl. 40, fig. 13) and the Sussex coast (Withers, 1935, pl. 40, fig. 12) identified as terga of L. laevissima cannot belong to Loriculina, because the new material of $L$. ifrimae sp. nov. demonstrates that the terga of the genus are flat and rectangular. East Harnham has also yielded three similarly large, rhombic, and highly distinctive scuta, one of which is the type of Stramentum expansum (see Withers 1911), here placed in Parastramentum gen. nov. The comparably large size of the scuta and terga, the distinctive sculpture of clustered growth lines with a faint radial sculpture and the similarity of the terga to those of Parastramentum gen. nov., make it likely that they also belong to $P$. expansum. This is confirmed by the association of terga and scuta of equivalent types from the Campanian Chalk of Norwich, here described as Parastramentum peakei gen. et sp. nov. 
Loriculina laevissima (von Zittel, 1885)

Fig. 9B

1885 Loricula laevissima von Zittel; 589, fig. 4.

1885 Loriculina laevissima Zittel; Dames: 155, fig. 3.

p.1935 Loriculina laevissima (Zittel); Withers: 305, pl. 40, fig. 2 only.

Diagnosis. Loriculina in which the scutum is relatively low, with the angle between the basal and upper lateral margins of the scutum obtuse $\left(120^{\circ}\right)$ and straight; the ratio between the length of the basal margin and the height is low (1.3); the basal margin of the upper latus contacts a single peduncular plate.

Type. The unique holotype figured by von Zittel (1885) and Withers (1935) is from the Oberer Kreidemergel of Dülmen, Westphalia, Germany. According to Kennedy \& Kaplan (1989), the Dülmen localities are lower Campanian, granulataquadrata and quadrata/lingua zones (sensu germanico). Bayerische Staatssammlung für Paläontologie und historische Geologie, München (see Withers 1935). A cast of the specimen is NHMUK In. 59713.

Loriculina noetlingi Dames, 1885

Fig. 9C, F

1885 Loriculina noetlingi Dames;152, fig. 4.

1935 Loriculina noetlingi Dames; Withers: 308, pl. 40, fig. 14.

Diagnosis. Loriculina in which the scutum is upright, the angle between the basal and upper lateral margin is relatively acute $\left(100^{\circ}\right)$, and the ratio between the length of the basal margin and the height is high (1.7); the basal margin of the upper latus contacts two peduncular plates.

Type. The unique holotype is from the Fish Bed at Sahel Alma, Lebanon, which has been dated as late Santonian on the basis of planktic foraminifera 
(Ejel \& Dubertret 1977). I reproduce a recent image of the specimen, taken by the late Martyn Whyte, which shows that it has suffered damage since 1935. Museum für Naturkunde, Berlin.

Remarks. Loriculina noetlingi is distinguished from congeners by the lower scutum, and the broader upper latus column of peduncular plates.

\section{Loriculina ifrimae sp. nov.}

Figs. 9A, 10

p.2011 Stramentum pulchellum (Sowerby); Ifrim et al.: fig. 5/5, 6 only.

Diagnosis. Loriculina in which the scutum is low; the angle between the basal margin and that with the upper latus is obtuse $\left(120^{\circ}\right)$ and the ratio between the length of the basal margin and the height is low (1.1). The contact between the scutum and the upper latus is markedly curved. The basal margin of the upper latus contacts three peduncular plates.

Type specimens. Holotype is the individual figured by Ifrim et al. (2011, fig. 5/6, refigured here (Fig. 10B), the other figured specimens are paratypes. All are attached to an ammonite, Peroniceras, lower Coniacian, Yellow Limestone Member, Carranza Quarry, Coahuila, Mexico. CPC-159.

Derivation of name. For my friend Christina Ifrim, who found and figured the type specimens.

Description. Fifteen specimens, in various states of completeness, from piles of valves to complete, articulated individuals are present on the flank of the Peroniceras. The body is oval with nearly symmetrical taper to the apex of the capitulum and the attachment site and the long axis is approximately twice the maximum width, which falls at the level of the rostrum. The capitular angle between the base of the capitulum and the long axis of the peduncle is acute (c. $50^{\circ}$, as compared to $70^{\circ}$ in Stramentum elegans - see below), and the 
occludent margin is slightly convex; the tergum and scutum each make up $50 \%$ of the occludent margin. The apex of the capitulum is coincident with that of the tergum, and is positioned slightly to the tergal side of the long axis of the peduncle. The arrangement, shape and orientation of the capitular plates is highly distinctive; the apices of the scutum and upper latus are close together, and both are inclined markedly towards the tergum. Secondly, and most distinctively, the tergum lies above the carinolatus, and their contact is subparallel with the base of the capitulum.

The scutum is triangular, and strongly inclined towards the tergum. The upper lateral margin is concave, the occludent margin gently convex. The interior of the scutum is smooth and concave, without a shelf above the scutal adductor. The carina is tall, narrow and the apex lies close to that of the tergum. The tergum is rectangular; thelong occludent margin is parallel with the carinal lateral margin and the short upper lateral margin is set at right angles to these. The plate is three times as broad as high, and the umbo is positioned centrally at the summit of a short carinal margin. The growth lines are parallel with the carinolateral margin, and inflect sharply to run parallel with the upper lateral margin. The carinolatus is triangular, but the margin which contacts the upper latus is truncated. The acutely pointed apex is situated at the point of contact with the carina and tergum. The basal and tergal margins taper gradually towards the upper latus. The growth lines run subparallel with the basal margin, but inflect towards the apex in the central portion of the plate. The upper latus is triangular and the scutal margin is convex; the tergal margin is straight.

The peduncle has a morphology typical of Loriculina (see above), in which the contact between plates of the carinolatus and upper latus columns is flat or slightly concavo-convex and, opposed, not interpenetrant. The plates of the rostral column are $V$-shaped with rounded wings, which diverge apically. Plates of the carinal column are rectangular and gently convex.

Remarks. Loriculina ifrimae sp. nov. is closest to L. laevissima, from which it differs in possession of a strongly curved margin between the scutum and upper latus (straight in L. laevissima), and the proportionately broader and taller peduncular plates of the upper latus column. 


\section{Loriculina sp.}

vp.1935 Loriculina laevissima (Dames); Withers: pl. 40, figs. 6, 7 only.

Material. Three fragmentary scuta from the Holaster planus Zone, upper Turonian, of Froxfield, Hampshire. Pit no. 125 of Brydone (1912), close to junction of Barnet Side Lane and King's Lane, Froxfield, $5 \mathrm{~km}$ northwest of Petersfield, Hampshire. SM 704275. NHMUK In. 32485, 32486.

Remarks. The only specimens figured by Withers (1935) from the English Chalk as Loriculina which can be referred to the revised concept of the genus are two fragmentary scuta in the NHMUK collections, and a further fragment in the SM collections. These are smooth, thin, concavo-convex, with convex occludent margins, and a narrow depressed rim parallel with the occludent margin. They cannot be assigned to any species at present. Valves referred to as terga of $L$. laevissima from the same locality are actually terga of Parastramentum gen. nov. (see below).

Loriculina? colombiana (Royo y Gomez, 1941)

1941 Loricula colombiana Royo y Gomez; 210, figs. 1-3.

Type specimens. The material figured by Royo y Gomez (1941); the individual from the Albian of Calera de La Frontera, Colombia, is here designated lectotype. Current whereabouts unknown.

Remarks. The illustrations of Royo y Gomez (1941), particularly his fig 3, show a stramentid with an apparent apical scutal umbo, and a transversely arranged tergum and carinolatus, which suggest affinity with Loriculina. However, the peduncular plates are much more like those of Stramentum, in that there is extensive interdigitation between the plates of the upper latus and 
carinolatus columns, rather than the opposed plates seen in Loriculina. In the end, the illustrations are not adequate enough to be sure of the generic affinity.

Genus Metaloriculina gen. nov.

Type species. Metaloriculina stramentoides sp. nov.

Diagnosis. Loriculinae in which the scutal umbo is positioned centrally to subcentrally (5-6/10), and the rhombic scutum has a pointed apex.

Derivation of name. From the Greek word meta, meaning beyond, with reference to the differences which separate the genus from Loriculina.

Referred species. Metaloriculina norvicensis sp. nov. from the upper Campanian of Norfolk, UK.

Remarks. Among the stramentids adherent to Peroniceras tridorsatum from Carranza Quarry, Coahuila, Mexico, are some six small individuals which have capitular valves of similar morphology to those of Loriculina (transverse, rectangular terga, triangular, transversely arranged carinolatera), but which possess centrally positioned scutal umbones like those in the stramentines Stramentum and Parastramentum gen. nov., yet have a tall, acuminate apical process on the scutum. Isolated valves from the Upper Campanian of Norwich, Norfolk, UK are referred to the same genus, as the tergal morphology is typical of Loriculinae nov., but the associated scuta have a central umbo.

\section{Metaloriculina stramentoides sp.nov.}

Fig. 12

p. 2011Stramentum pulchellum(Sowerby); Ifrim et al.: fig. 5/5 only.

Holotype. Individual figured by Ifrim et al. (2011, fig. 5/5), refigured here (Fig. 12B). The other individuals figured here (Fig. 12A, C, D) are paratypes. 
Attached to Peroniceras tridorsatum, lower Coniacian, Yellow Limestone Member, Carranza Quarry, Coahuila, Mexico. CPC-159.

Diagnosis. Metaloriculina in which the apical portion of the scutum is tall and pointed.

Derivation of name. With reference to the Stramentum-like scutum of the genus.

Descripition. The body form is asymmetrically oval, the capitular angle moderately high $\left(120^{\circ}\right)$ and the occludent margin is convex. All plates display prominent growth lines. The tergum and carinolatus are flat, transversely elongated, and the margin between these plates is acutely angled to the base of the capitulum. The tergum is trapezoidal in outline with a straight carinolateral margin and a gently convex occludent margin. The growth lines run parallel to the upper lateral margin across most of the surface of the plate, and inflect apically close to the carinolateral margin. The carinolatus is triangular with a long basal margin, and the narrow, tall carina articulates with the straight carinal margin of the carinolatus. The upper latus is triangular, slightly broader than high, the scutal margin is slightly convex, and the tergal margin slightly concave. The scutum is nearly rhombic in outline, has a large umbonal angle $\left(150-170^{\circ}\right)$, and a tall, pointed apex with an acute apical angle $\left(35-40^{\circ}\right)$. The umbo is central to subcentral (5-6/10). The basilateral angle openly rounded and quite obtuse $\left(110^{\circ}\right)$, the basal angle acute $\left(60^{\circ}\right)$.

The peduncular plates of the three lateral columns are four times broader than high, and those of the upper latus column are strongly crescentic. The plates of the scutum and upper latus columns interdigitate strongly, and the plates of the upper latus and carinolatus columns have a flat or gently concavo-convex contact and oppose. Plates of the carinal column are rectangular and slightly asymmetrical. No rostral column plates are visible on any individual. 
Remarks. The loriculine affinities of this species are shown by the shape and arrangement of the tergum and carinolatus, the articulation of the peduncular columns (opposing, flat carinolatus-upper latus column contact), and the form of the carinal column.

\section{Metaloriculina norvicensis sp. nov.}

Figs. 13, 23I-K

Types. The holotype is the carinolatus figured (Fig. 13E; NHMUK IC 1226). Other figured plates are paratypes (NHMUK IC 1223-5, IC 1227-1232).

Diagnosis. Metaloriculina in which the apex of the scutum is short and not pointed; there is a discrete tergal surface on the carinolatus.

Derivation of name. After the Roman name for the city of Norwich, Norvica, where the type material was collected.

Material. Three carinolatera, one upper latus, three scuta, 25 peduncular plates, from sample levels Cr1-3, Cringleford Newfound Farm Pit, Norwich, Norfolk, UK; peduncular plates from Keswick, Norwich. Echinocorys conica level, Belemnitella mucronata Zone, upper Campanian (Wood 1988). The identification of plates is made with reference to articulated material of $M$. stramentoides sp. nov. from Mexico.

Description. The carinolatus (Fig. 13B,E) is flat, subtriangular and elongated, with straight margins ( $2.5 \mathrm{x}$ longer than high). The tergal margin is long and straight, and is set at right angles to the short upper lateral margin. The carinal margin is straight and acutely angled $\left(25^{\circ}\right)$ to the tergal margin. The growth lines run parallel with the basal margin on the lower part of the plate, then deflect up to the tergal margin, parallel with the upper lateral margin. The upper latus is triangular, as tall as broad, and the scutal margin is convex; the tergal margin is slightly concave. The scutum (Fig. 23I-K) is rhombic, with an acute rostral angle $\left(60^{\circ}\right)$, a strongly obtuse umbonal angle $\left(150^{\circ}\right)$ and an 
obtuse basilateral angle $\left(115^{\circ}\right)$. The umbo is approximately central in position $(4-5 / 10)$.

All columns of peduncular plates are represented in the material, and can be confidently referred to their correct positions with reference to articulated material of $M$. stramentoides sp. nov. The arrangement of the plates is illustrated in Fig. 11. Plates of the rostral column are highly distinctive, V-shaped and flat, with apically divergent wing-like processes, and on the interior surface bear a vertical median groove (Fig. 13F, G). The growth lines deflect downwards on the lateral tips of the wings. The most apically positioned plates are symmetrical, the wings diverge at a relatively acute angle $\left(60^{\circ}\right)$ and the groove is partially covered by two lateral processes. In plates from lower down the column (Fig. 13H), the angle between the wings is more obtuse $\left(70-75^{\circ}\right)$, the wings are markedly asymmetrical and the median groove is open.

Plates of the scutal column (Fig. 13C, D) are concavo-convex and asymmetrically crescentic, with upturned lateral processes of different lengths. In apical view, the shorter rostral side is strongly inflexed at about $120^{\circ}$. The side which forms an interdigitation with the upper latus column is elongated and tapers to a point. The plates of the upper latus column (Fig. 13A) are broadly rectangular, but taper laterally to a downturned process which interdigitates with the plates of the scutal column. The margin which contacts plates of the carinolatus column is squared off, with a short downwardly directed process at the tip. In plates from large individuals, short, laterally directed articular processes protrude from the lower, lateral margins. Plates of carinolatus column (Fig. 13I, K) are trapezoidal, approximately four times broader than high, and flat. The lateral margins diverge apically. The plates of the carinal column are rectangular, slightly asymmetrical and weakly convex. The apical margin is sigmoidally curved, and the growth lines on the upper part of the plate parallel the margin.

Remarks. Metaloriculina norvicensis sp. nov. differs significantly from $M$. stramentoides sp. nov. in carinolatus and scutal morphology. In the former there is a discrete tergal surface on the carinolatus, absent in $M$. stramentoides sp. nov. The scutum lacks a pointed apex. 
Subfamily Stramentinae Withers, 1920 nom. corr.

Diagnosis. Stramentidae in which the contact between the carinolatus and tergum is set obliquely at $45-55^{\circ}$ to the base of the capitulum; rostral and carinal peduncular plate columns are rectangular and similar in shape, and plates of the carinolatus and upper latus columns interdigitate.

Remarks. The discovery of the complete morphology of Loriculina, in particular the very distinctive rectangular tergum, which is set subparallel to the base of the capitulum, necessitates separation of the Stramentidae into two groups. The position of the scutal umbo is no longer a useful criterion, because this can be both apical and subapical in forms close to both Loriculina and Stramentum, so the shape and orientation of the tergum and carinolatus, and the contacts of the peduncular plate columns are used to define the two subfamilies. Four genera of stramentine are recognised here, namely Angulatergum Hauschke, 1994, Leweslepas gen. nov., Stramentum Logan, 1897 and Parastramentum gen. nov.

Phylogeny. During the present study, it became evident that species here referred to Leweslepas gen. nov. and Stramentum form a stratigraphically constrained morphocline which evolved through the Cenomanian and Turonian (Fig. 29). The earliest species in this succession is Leweslepas hauschkei gen. et sp. nov. from the lower Cenomanian Mantelliceras dixoni Zone of Sussex, UK, which has apical scutal umbones and a transverse capitular basal margin (low capitular angle). This is succeeded by Stramentum praecursor sp. nov. from the Turrilites costatus Subzone of the middle Cenomanian Acanthoceras rhotomagense Zone, in which the scutal umbones are subapical, but which also retains a transverse capitular base. In the late Cenomanian Metoicoceras geslinianum Zone appears Stramentum pulchellum, and this survives into the upper Turonian in the UK, Germany and the Czech Republic. The transitions are accompanied by other minor yet 
significant morphological changes. Parastramentum gen. nov., from the upper Turonian to Campanian, subsequently evolved from Stramentum.

Genus Angulatergum Hauschke, 1994

Diagnosis. Stramentinae in which the tergum is asymmetrically rhombic, and the growth lines $\mathrm{V}$ down towards the basal angle; scutum with high subapical umbo (2-3/10) and short, pointed apical process; upper latus nearly symmetrical isoceles triangle.

Type species. Scalpellum moorei Hattin,1977, designated herein.

Referred species. Loricula syriacum Dames,1878 and Loriculina texanum Withers, 1945.

Description (based on A. moorei, the only well-known species of the genus; Fig. 21). The overall form in lateral aspect is asymmetrically oval; the capitulum is proportionately tall, and forms about one-third of total body height. The capitular angle is relatively obtuse $\left(75^{\circ}\right)$ and the occludent margin is slightly convex. The rostrum is small, convex and triangular, and occupies one-third of the height of the rostral margin of the scutum. The scutum is very distinctive, as the umbo is high (2-3/10) and the apical part, above the umbo, forms a short, acuminate process. The rostral angle is acute $\left(55^{\circ}\right)$, the basilateral angle relatively obtuse $\left(110^{\circ}\right)$. The surface of the scutum adjacent to the upper lateral margin is slightly depressed. The upper latus is a perfect isoceles triangle, slightly taller than broad, in small individuals, but develops a slight asymmetry in fully-grown specimens, with the basitergal angle at $90^{\circ}$. Growth lines on the upper latus are deflected apically adjacent to the tergal margin. The tergum is asymmetrically rhombic in outline, and is divided into two subequal parts along a line running from the umbo to the basal angle, along which the growth lines diverge upwards. The surface of the carinal side of the valve is about half the size of that on the occludent-upper latus surface. The growth lines deflect apically close to the occludent margin, and two weak ridges, and an intervening groove run close to, but subparallel with, the 
occludent margin. The carinolatus has the outline of an obtuse isoceles triangle, of which the longest margin is the tergal, and the valve overlaps the lower part of the tergum. The growth lines deflect sharply upwards close to the tergal margin. The carina is tall and narrow.

The peduncular plates are two to three times as broad as tall, and the carinolatus, upper latus and scutal columns only interdiditate slightly.

Remarks. The genus is best known from numerous specimens of $A$. moorei (Hattin, 1977) from the middle Cenomanian of Kansas, which form the basis for the present description. Otherwise, the genus is known exclusively from two small individuals, one from the middle Albian of Texas and the other from the Albian of Lebanon, referred to the genus on the form of the tergum.

Affinities and phylogenetic relationships of Angulatergum. The genus appears to be basal to the Stramentinae because the occludent and carinolateral margins of the tergum are subparallel as in Loriculinae, and the scutal umbo has a high position. Angulatergum perhaps shared a common ancestor with Leweslepas gen. nov., with which it shares the large overlap of the tergum by the carinolatus the upward deflection of growth lines on the tergum close to the carinolateral margin and Ithe low capitular angle. This deflection and overlap are not present in Stramentum. Angulatergum ranges from the middle Albian to the middle Cenomanian, which supports its inferred basal position.

Angulatergum moorei (Hattin, 1977)

Fig. 21

1977 Stramentum moorei Hattin; 818, pl. 3, figs.1-12; pl. 4, figs. 1-24. 1994 Stramentum (Angulatergum) moorei Hattin; Hauschke: 14.

Diagnosis. Angulatergum in which peduncular plate columns are only weakly interdigitate, and the upper margin of the median column is almost flat. 
Material. The holotype (KU 111588) and paratypes (KU 111589-111619, KU 111635-111660) are all from a single lens $1.7 \mathrm{~m}$ above the base of the Lincoln Member, Greenhorn Limestone, Bunker Hill, Russell County, Kansas (Hattin 1977). Middle Cenomanian, Plesiacanthoceras wyomingense Zone.

Discussion. Angulatergum moorei differs from both $A$. syriacum and $A$. texanum in the weaker interdigitation of the peduncular plate columns, and the almost flat upper margin of the median latus column.

Angulatergum syriacum (Dames, 1878)

1878 Loricula syriaca Dames; 70.

1884 Loricula syriaca Dames; von Zittel: 589, fig. 5.

1935 Stramentum syriacum (Dames); Withers: 315, pl. 42, fig. 2.

1994 Stramentum (Angulatergum) syriacum (Dames); Hauschke: 14, fig. $6 \mathrm{~b}$.

Type. A single specimen attached to the internal mould of an ammonite, Buchiceras, Albian, Lebanon. Museum für Naturkunde, Berlin.

Diagnosis. Angulatergum in which the apical margin of peduncular plates of the median column is strongly convex.

Remarks. The unique type is a small individual, and the surfaces of the capitular plates are poorly preserved (Withers 1935, p. 316), such that it is not possible to be certain about the precise position of the scutal umbo. However, the tergum with 'angles of growth situated almost in the middle of the valve' (Withers 1935, p. 316) are characteristic of Angulatergum.

Angulatergum texanum (Withers, 1945)

Fig. 28C

1945 Loriculina? texanum Withers; 557, fig. 7.

1994 Stramentum (Angulatergum) texanum (Withers); Hauschke: 14. 
Types. A small specimen from the Walnut Formation (middle Albian) of Nolan Creek, east of Nolanville, Bell Co., Texas, attached to an ammonite, Oxytropidoceras. University of Texas collections, Austin, no. 2500.

Diagnosis. Angulatergum in which the plates of the median latus, carinolatus and scutal peduncular columns interdigitate strongly, but in which the apical margin of the median column is only gently convex.

Remarks. The single small individual is incomplete; the upper half of the scutum is missing, but as Withers (1935, p. 558) noted, the tergum has Vshaped growth lines, confirming its placement in Angulatergum (Hauschke 1994).

\section{Genus Leweslepas nov.}

Diagnosis. Stramentinae in whichthe umbo of the scutum is apical in position, and the upper latus approximates an acute isoceles triangle in outline. The occludent margin is convex; the growth lines on the carinal lateral margin of the tergum deflect sharply towards the apex, and this region is overlapped strongly by the carinolatus; capitular angle low.

Type species. Leweslepas hattini sp. nov.

Included species. Leweslepas hattini sp. nov., L. hauschkei sp. nov., Pollicipes acuminatus Darwin, 1851b, Scalpellum obsoletum Geinitz, 1875 and $L$. wrightorum sp. nov.

Remarks. Leweslepas gen. nov. is demarcated from Stramentum, to which $L$. hauschkei sp. nov. is ancestral, by the apical scutal umbones, the apically deflected growth lines on the carinolateral margin of the tergum, and the strong overlap of the carinolatus over the tergum. In Stramentum, the scutal umbones are subapical to central, the tergal growth lines run straight into the 
carinal lateral margin, and the contact between the tergum and the carinolatus is a narrow, chamfered, flat contact (Fig. 240). Leweslepas gen. nov. differs from Angulatergum, from which it probably evolved, in the triangular shape of the tergum, the position of the apicobasal line of the tergum close to the carinolateral margin, and the apical position of the scutal umbo.

As discussed above (Loriculina), the distinctive robust scuta with apical umbones and an internal platform above the scutal adductor, which have been traditionally referred to Loriculina, are quite different to the delicately constructed scuta of that genus, and are therefore placed in Leweslepas gen. nov. which has robust scuta with apical umbones. These include Pollicipes acuminatus and scuta from the Cenomanian Unterer Pläner of Saxony and the Turonian Pläner Kalk of Strehlen, close to Dresden (Germany), which are the types of Pollicipes conicus Reuss, 1875 (see also Withers 1935, pl. 40, figs. 3-5). The material from the lower Cenomanian Mantelliceras dixoni Zone of Lewes, Sussex, UK, includes two new species of the genus, L. hattini sp. nov. and $L$. hauschkei sp. nov., which are morphologically very distinct.

Derivation of name. After the town of Lewes in Sussex, where the holotypes of $L$. hattini sp. nov. and $L$. hauschkei sp. nov. were collected.

Age. Early Cenomanian to early Turonian.

\section{Leweslepas hattini sp. nov.}

Figs. 14A, B, 15A

Type. Holotype, a sole specimen known, is OUM K.38133, Mantelliceras dixoni Zone, lower Cenomanian, Southerham Grey Pit, Lewes, Sussex, Bed 48 of Kennedy \& Gale (in press), collected by A.S. Gale, 1987, attached to an ammonite, Acompsoceras sp.

Derivation of name. In honour of Don Hattin for his detailed work on North American stramentids. 
Diagnosis. Leweslepas gen. nov. in which the scutum is only slightly taller than broad, the occludent margin of the tergum short and the carinolatus tall and narrow.

Description. The holotype (Fig. 15A) is a near-complete articulated specimen, which appears to be fully grown. There has been some displacement in the middle part of the peduncle, the carinolatus and carina are slightly displaced from the restof the capitulum, and the upper latus lacks one basal corner. The tergum is partly obscured by the upper latus. In overall form the body is oval, with a bluntly rounded capitular end, and a more pointed proximal one. The base of the capitulum is set nearly at right angles to the median axis of the peduncle, with a capitular angle close to $90^{\circ}$.

The capitulum is low, representing about $25 \%$ of the height of the individual. The occludent margin is convex and slightly inflexed at the level of the apex of the upper latus. The apices of the carina, carinolatus and tergum converge, and lie close to each other. The rostrum has a convex median margin, and its height is about one-third of that of the scutum. The scutum is triangular, with a strongly convex occludent margin, and a straight basal margin. The scutal umbo is apical, and well-marked growth lines run parallel with the basal margin, and swing up sharply to the upper lateral margin. The upper latus is an isosceles triangle in outline, and is slightly taller than broad. The tergum is incompletely exposed as it is partly covered by the upper latus; it is triangular in form with a straight basal margin, and a slightly convex contact with the carinolatus. The occludent margin is short, and the carinolateral margin strongly overlapped by the carinolatus, the growth lines deflecting upwards on this surface. The carinolatus is narrow, triangular and tall, the tergal margin is concave, and the carinal margin convex. The carina is as tall as the carinolatus, and its contact with that plate is concave.

The peduncular plates have a convex exterior surface and are unusually thick for stramentids. The plates of the upper latus column are two to three times broader than tall, crescentic, and the upper margin is convex, the basal one slightly concave. The plates of the carinolatal and scutal columns alternate and interdigitate with those of the upper latus column; they are asymmetrically 
oval. The plates of the rostral and carinal columns are oval-rectangular, and alternate with those of the scutal and carinolateral columns.

Discussion. The reconstruction (Fig. 14B) shows the overall form of the species for comparison with other stramentids. The capitulum is low, and the umbones of the tergum, carinolatus and carina all converge; the tergum is partly overlapped by the upper latus and carinolatus. The rostrum is larger than in any stramentid other than Blastolepas. Leweslepas hattini sp. nov. differs from L. hauschkei sp. nov. in the larger rostrum, the shape of the scutum, the shorter occludent margin of the tergum, and the taller, narrow carinolatus. It differs from other species of the genus in its strongly convex scutum, with a convex occludent margin.

\section{Leweslepas hauschkei sp.nov.}

Fig. 15B-D

Material and types. The material comprises four variably articulated individuals on the flank of an ammonite (Acompsoceras). The most complete of these is the holotype (OUM K.64093), the others are paratypes (OUM K.64094-6). Lower Cenomanian, Mantelliceras dixoni Zone, Bed 62 (Kennedy \& Gale (in press), $2.5 \mathrm{~m}$ below base of middle Cenomanian), Southerham Grey Pit, Lewes, Sussex, collected by A.S. Gale (1987).

Diagnosis. Leweslepas in which the scutum is tall and erect, the rostrum is low and broad, the tergum has a long occludent margin and the carinolatus is low and broad.

Derivation of name. In honour of Norbert Hauschke for his important work on stramentids.

Description. The holotype individual has split post mortem into a basal region of the peduncle which is detached from the almost perfectly articulated upper peduncle and capitulum, which lacks only the carina (Fig. 15C, D). The 
occludent margin is convex, and the triangular rostrum is broader than high. The scutum is triangular, tall and erect in appearance and the umbo is apically positioned. The rostral angle is acute $\left(63^{\circ}\right)$, the basilateral angle slightly obtuse $\left(105^{\circ}\right)$; the occludent margin convex. The upper latus is nearly an isoceles triangle in outline, but the basiscutal angle is acute, and the basitergal angle nearly $90^{\circ}$. The umbo of the upper latus is positioned adjacent to that of the scutum. The tergum is equilaterally triangular, and the the occludent margin is long and straight; the growth lines are deflected apically adjacent to the occludent margin. The growth lines on the lower portion of the plate, adjacent to the carinolateral margin, are also deflected apically, and this region of the tergum is strongly overlapped by the carinolatus (Fig. 15C). The carinolatus has the outline of an obtuse isoceles triangle, in which the longest side is the tergal margin; it is as broad as high. Peduncular plates of the upper latus column are crescentic, apically convex, nearly symmetrical, and approximately four times broader than high; they alternate with and interdigitate strongly with plates of the scutal and carinolateral columns. Plates of the rostral column are rectangular, and change from broad and low (uppermost plate, in contact with the rostrum) to taller than broad ( $4^{\text {th }}$ plate down from rostrum). The contact between plates of the scutal and rostral columns asymmetrically alternates, and is nearly flat.

Affinities. Leweslepas hauschkei sp. nov. is most closely comparable with $L$. acuminata in the shape of the scutum, but differs in the more acute rostral angle, and more obtuse basilateral angle, and lacks the flattened upper lateral surface of that species. It differs from L. hattini sp. nov. in the size and shape of the rostrum and scutum, the shape of the tergum (short occludent margin in L. hattini sp. nov., long in L. hauschkei sp. nov.), and the broad, low carinolatus, which is short and tall in the former. From Stramentum praecursor sp. nov., to which it is ancestral, it differs in the apical position of the scutal umbones, the presence of a marked overlap of the carinolatus over the tergum, and the apically deflected growth lines beneath this overlap. 
1851a Pollicipes acuminatus Darwin; 56, pl. 3, fig. 6a, b. 1935 Loriculina acuminata (Darwin); Withers: 304, pl. 40, fig. 1.

Diagnosis. Leweslepas with a tall, narrow scutum, the basal margin of which is set at right angles to the lower part of the concave upper lateral margin. Prominent growth lines run parallel with the basal margin, and upturn sharply to run subparallel with the tergal margin. The occludent margin is strongly and evenly convex, and the apex is inclined towards the tergum.

Type specimen. The scutum, figured by Darwin, from the Lower Chalk (probably Cenomanian) of Stoke Ferry, Norfolk, in the "Mus. Flower" (Darwin 1851a). Current whereabouts unknown, probably lost.

\section{Leweslepas obsoleta (Geinitz, 1875)}

1875 Scalpellum obsoletum Geinitz: 288, pl. 44, fig. 16.

p 1875 Pollicipes conicus Reuss: Geinitz, 204, pl. 37, fig. 29, 29a only.

p.1935 Loriculina laevissima (von Zittel); Withers: 305, pl. 40, figs. 3-5 only.

Types. The scutum figured by Geinitz (1875) and Withers (1935, pl. 40, fig. $4 a, b)$ from the Turonian Pläner Kalk of Strehlen, Saxony, Germany, is selected as lectotype. Collections of the Senckenberg naturhistorische Sammlungen, Dresden.

Diagnosis. Leweslepas in which the scutum is twice as tall as broad. The occludent margin is gently convex, and the basal margin is angled at $110^{\circ}$ to the straight tergal margin.

Discussion. Although the outline of the scutum is very similar to that of Loriculina, the valves were clearly robust, and possessed a shelf above the scutal adductor as shown by Withers's photograph of the interior of a valve 
(1935, pl. 40, fig. 4b) and the species is therefore provisionally placed in Leweslepas gen. nov.

\section{Leweslepas wrightorum sp. nov.}

Fig. 15F

Diagnosis. Leweslepas with a very tall narrow scutum, more than three times taller than broad. The basal margin is angled at $50^{\circ}$ to the straight tergal margin.

Type specimen. The holotype is a scutum from the Schloenbachia varians Zone (= lower Cenomanian) Lower Chalk of Compton Bay, Isle of Wight, UK. C.W. and E.V. Wright Collection, NHMUK In. 63529.

Derivation of name. In honour of the late brothers C.W. and E.V. Wright, extraordinary collectors of Cretaceous fossils and celebrated amateur scientists.

Description. The scutum (Fig.15F) is tall and narrow, and has the form of a scalene triangle, with three unequal sides; the gently convex occludent margin is the longest, the basal margin the shortest. The rostral angle is acute $\left(50^{\circ}\right)$, the basilateral angle obtuse $\left(130^{\circ}\right)$. The surface of the valve adjacent to the upper lateral margin is slighly deflected and flattened for articulation with the upper latus. The basal and upper lateral margins are straight, and a shallow, poorly defined groove runs from the apex to the basal margin, subparallel with the occludent margin. The well-marked growth lines run parallel with the basal margin, but deflect sharply towards the apex close to the upper lateral margin.

Remarks. The high basilateral angle and acute rostral angle separate $L$. wrightorum sp. nov. from other species of the genus. The scutum was very noticeably inclined towards the tergum, far more so than in $L$. acuminata, $L$. hattini sp. nov. and L. obsoleta. 
Type species. Pollicipes haworthi Williston, 1896, by subsequent designation of Withers 1920, p. 68.

Diagnosis. Stramentinae in which the scutal umbo is subapical to central in position; the tergum is flat and triangular with transverse growth lines parallel with the upper lateral margin which reflexes apically close to the occludent margin; carinolatus and tergum do not overlap, and growth lines on the tergum are not deflected at the carinolateral margin.

Remarks. Many of the long-held misconceptions and myths which formerly attended the morphological understanding of Stramentum (see Withers 1935 - the split carina, lack of a rostrum, number of plate columns) were dealt with thoroughly by Hattin (1977) and do not need further discussion here. An important paper by Hauschke (1994) subdivided Stramentum into Stramentum (Stramentum), characterised by straight growth lines on the tergum, and Stramentum (Angulotergum) with V-shaped tergal growth lines. Further important differences are noted here, and Angulotergum is therefore elevated to full generic rank.

Discussion. A number of species of Stramentum have been described which are based upon specifically indeterminate articulated material, or incorrectly assigned valves. These include:

1) Stramentum saadensis Davadie \& Emberger, 1955. Indeterminate Stramentinae, no capitular valves. Albian, Algeria.

2) Stramentum biplicatum Jagt \& Collins, 1989 from the upper Campanian of Haccourt, Belgium is based on a large scutum (Fig. 23C, D; NHMUK In. 63637). However, the obtuse basal-occludent angle, the strong taper to an acuminate apex, and the shape of the valve indicates that it is referable to the zeugmatolepadid Zeugmatolepas cretae (Steenstrup, 
1839). Typical Z. cretae from the upper Campanian of Norwich are figured for comparison (Fig. 23A, B).

3) Stramentum cf. pulchellum of Jagt \& Collins (1989, p. 90) is also a scutum of Z. cretae (NHMUK In. 63638).

Stramentum shows a stratigraphical evolutionary morphocline, the early Cenomanian Leweslepas hauschkei gen. et sp. nov. evolving into the middle Cenomanian Stramentum praecursor sp. nov., and on into the late Cenomanian-Turonian S. pulchellum in western Europe. The lineage split in the early Turonian, and S. pulchellum gave rise to $S$. canadensis in the early Turonian, which subsequently evolved into the middle Turonian S. elegans (both only known from the Western Interior Basin of North America).

Similarities in scutal structure allow one to infer that $S$. elegans, or a species close to it, was ancestral to Parastramentum gen nov. which appears in the upper Turonian and continues to the end of the Campanian. Stramentum pulchellum continued into the upper Turonian in the UK, while Stramentum inconstans, from the lower Turonian of Nigeria, probably evolved from $S$. praecursor sp. nov.and S. haworthi from the Santonian of Kansas also probably represents an offshoot of $S$. pulchellum. Detailed evidence for the relationships are discussed with regard to individual species.

Stramentum can be divided into a number of precisely defined species using the shapes of the capitular valves, particularly the tergum and scutum, but also the upper latus and carinolatus. Most of the North American species were thoroughly described by Hattin (1977) and these are only reviewed briefly here. Stramentum haworthi from the Santonian Niobrara Chalk of Kansas is refigured and redescribed on the basis of extensive material in the NHMUK collections.

Ontogeny. There has been some confusion regarding the identification of 'young' and 'fully-grown' specimens of stramentids. For Withers, small individuals were identified as young ones, such as the small specimen of $S$. pulchellum he figured (1935, pl. 41, fig.1), and the small type specimens of Loriculina spp. (see above). However, new peduncular plate rows were 
evidently generated throughout life, because the largest specimens known show incipiently developed, new plates forming at the junction with the capitulum (Fig. 16C). The number of peduncular plate rows can therefore serve as a useful proxy for the relative age of individuals. This was tested by cross-plotting number of plate rows in the upper latus column against the total height of articulated individuals, which shows a straight line correlation for $S$. pulchellum and S. inconstans (Fig. 17).

Ontogenetic change in Stramentum is best known in S. pulchellum (see Hauschke 1994), and also seen in S. elegans (Hattin 1977, pl. 1, figs 4-6, refigured here as Fig. 22) and S. inconstans (Fig. 18). There are a number of ontogenetic changes which are consistent between some species, including increase in number of peduncular plate rows. The upper latus column plates show three distinct ontogenetic stages (Fig. 17C):

- A, characterised by progressive increase in width and slight gradual increase in height (first 10-12 plates)

- $\quad$ B, plates retain constant and maximum breadth and height (about 10 plates)

- C, width and height decrease (last-formed 4-5 plates in the largest individuals known), and the plates becomes slightly slanted down towards the rostral side (Figs. 16C, 17D, 22B, C, 28D, E).

Plates in the s and cl columns also show corresponding A and B stages, but retain maximum width through the $C$ stage, during which the plates decrease progressively in height. The stages must relate to discrete phases in life history, and the presence of the $\mathrm{C}$ stage can be taken as an indicator of fullygrown individuals, rather like the crowding of septa towards the body chamber seen in adult ammonites (Kennedy \& Cobban 1976). This is very useful because it permits an assessment of age and maturity additional to plate row numbers. Thus, the small specimen taken as holotype of $S$. praecursor sp. nov. can be shown to be fully mature, as it has reached the $C$ stage, rather than representing a young individual (see Withers 1935). 
In addition to these overall similarities, species of Stramentum show individually distinctive ontogenetic trajectories which have taxonomic significance, discussed below.

\section{Stramentum praecursor sp.nov.}

Figs. 16D, 26B, C

vp.1935. Stramentum pulchellum (G.B. Sowerby); Withers: pl. 41, fig. 1 only.

v.1977. Stramentum pulchellum (G.B. Sowerby); Hattin: pl. 1, fig. 3 only.

?1993 Stramentum pulchellum (G.B. Sowerby, jun.); Breton \& Boiné: figs 1-5, pl. 1.

Holotype. The complete, well-preserved individual figured by Withers (1935) and Hattin (1977), SM B.8935. No locality details. The specimen is attached to an ammonite, Acanthoceras rhotomagense, and came from the Turrilites costatus Subzone, level of couplets C5 to C11 of the Lower Chalk (Gale 1995) in Kent or Sussex, where A. rhotomagense is common and well preserved. Paratype is a smaller specimen also attached to A. rhotomagense, inferred to be from the same level at Glynde, near Lewes, Sussex, UK. BM 00686.

Other referred material. The five individuals attached to Acompsoceras sp. from the Craie de Rouen, Acanthoceras rhotomagense Zone of Cauville, Normandy, France, almost certainly belong to this species, as the scutal umbones are subapical in position (Breton \& Boiné 1993). MHNH 8708.

Diagnosis. A small species of Stramentum in which the peduncle is proportionately low and broad; the capitular angle is low (about $100^{\circ}$ ) and the rostral angleof the scutum is acute. The occludent margin of the scutum is strongly convex.

Origin of name. From the latin praecursor, to go before, as it is the oldest species of the genus. 
Description. The holotype is complete and well preserved, but there is minor displacement of the uppermost plates of the upper latus peduncular column. Additionally, the surface has been coated with a glue-like substance which obscures some features. The body form is low and squat, and is only slightly taller than broad. The base of the capitulum is set transversely and the capitular angle is high () the occludent margin is gently convex. The rostrum is small, low and triangular, the scutum rhomboidal. The scutal umbo is positioned subapically (3/10), and the occludent margin of the scutum is evenly convex, the umbo inconspicuous. The rostral angle is very acute $\left(45^{\circ}\right)$ the basilateral angle obtuse $\left(125^{\circ}\right)$, and the apex is acutely pointed. The outline of the upper latus is a right isoceles triangle, in which the basitergal angle is about $90^{\circ}$, and the tergal margin is slightly longer than the other two margins. The tergum is triangular, the occludent margin is slightly convex and the carinal lateral margin is straight, without overlap by the carinolatus. The outline of the low carinolatus is a right triangle, with a carinobasal angle of $90^{\circ}$; the carinal margin is short, and the carina is tall and narrow and tapers gradually to the (broken) apex.

Peduncular platesof the upper latus column are approximately symmetrical, strongly imbricated, have an elongated trapezoidal form, and are three to six times broader than tall. The plates of the carinolatus and scutal columns are three to five times broader than tall and asymmetrical, with a flat or slightly convex contact with the rostral and carinal columns and an elongated, strongly interdigitating contact with the upper latus column. The rostral and carinal columns comprise rectangular plates which alternate asymmetrically with the adjacent columns, such that a longer upper face contacts the higher plate of the adjacent column, and a short contact is made with the lower plate.

Remarks. Withers (1935, pl. 41) thought that the holotype specimen was a young individual of $S$. pulchellum, presumably on account of its small size. However, it possesses at least 18 peduncular plates in the central upper latus column and is therefore fully grown. Additionally, the ontogeny of $S$. pulchellum is now known (see below), and the specimen bears little resemblence to juveniles of that species (Fig. 17B). Stramentum praecursor 
sp. nov. is intermediate in morphology, and age, between Leweslepas hauschkei gen. et sp. nov. and Stramentum pulchellum. It differs from the former in its possession of a nearly central (rather than apical) scutal umbo, and in the form of the tergum, which is not overlapped by the carinolatus, and lacks the apically deflected growth lines on the tergum found in Leweslepas gen. nov., close to the carinolateral margin. It differs from S. pulchellum in the lower capitular angle, the shape of the upper latus, and the elongated form of the scutum, which has an acute rostral angle and a very obtuse rostrolateral angle. Also, the occludent margin of the scutum is markedly more convex.

Stramentum pulchellum (G.B. Sowerby Jr, 1843)

Figs. 16A-C, 17A-D, 18B, 24O, P

1843 Loricula pulchella G.B. Sowerby Jr: 260, figs. 1, 2.

1851a Loricula pulchella G.B. Sowerby; Darwin: 81, pl. 5, figs. 1-4.

1858 Loricula MacAdami Thomson, in MacAdam; 322, text-fig.

1878 Loricula gigas Fritsch: 147.

1887 Loricula pulchella Sowerby, var. gigas and var. minor Fritsch \& Kafka; 1, pl. 1.

1908a. Loricula darwini H. Woodward; 493, fig. 1.

1920. Stramentum pulchellum (G.B. Sowerby); Withers: 70, pl. 3, figs. 1-3, 264, fig. 1.

p1935 Stramentum pulchellum (G.B. Sowerby); Withers: 316, pl. 41, figs. 1-4

only, pl. 42, fig. 1.

non1977 Stramentum pulchellum (G.B. Sowerby); Hattin; pl. 1, fig. 3.

1989 Stramentum pulchellum (Sowerby); Oekentorp: 134, pl. 1 fig. 1; pl. 2,

figs. $3-4$; pl. 4, figs. 1-4.

non1993 Stramentum pulchellum (G.B. Sowerby); Breton \& Boiné; 20, figs. 1,

3-5; pl. 1, figs. 1-7.

1994 Stramentum (Stramentum) pulchellum (Sowerby); Hauschke: 15, pls 1-5. 1996 Stramentum (S.) pulchellum (Sowerby); Wittler; 94.

non2011 Stramentum (S.) pulchellum (Sowerby); Ifrim et al.; 527, fig. 5/1-11. 2011Stramentum (S.) pulchellum (Sowerby); Hauschke et al.; 202, figs. 3-5. 
2012 Stramentum (S.) pulchellum (Sowerby); Schöllmann \& Hauschke: 64, fig. 5 ; pl. 1, figs. 1-7.

2013 Stramentum (Stramentum) pulchellum (G.B. Sowerby jnr); Kočova Veselská et al.: 153, pl.1, figs. 1-9.

Diagnosis. Stramentum in which the occludent margin is straight to slightly convex, and the angle of the occludent margin to the base of the capitulum acute $\left(30^{\circ}\right)$; the scutal umbo is positionedcentrally $(4 / 10)$ and the umbonal angle of the scutum is very high, such that there is no inflection/inflexion of the lower occludent margin at the umbo; the region of the tergum adjacent to the occludent margin forms a discrete flange on which the growth lines deflect sharply towards the apex; the basal margin of the carinolatus is long. The upper latus is a slightly asymmetrical isoceles triangle in outline.

Ontogeny. The ontogeny of this species is the best understood of any Stramentum, because the species is known from both tiny individuals of a length of $3 \mathrm{~mm}$ (Hauschke 1994, pl. 4, figs. 2-4) up to large, fully-grown individuals of a length of over $40 \mathrm{~mm}$ (e.g., NHMUK In. 9130). General features of this ontogeny are:

1) There is little proportional change in shape of the capitular plates during later ontogeny (i.e. once all the capitular plates have formed), or of the capitular angle. The basal margin of the carinolatus becomes proportionately longer, and the length of the contact with the upper latus increases.

2) The peduncular plates increase progressively in number with growth (Fig. 17); they become proportionately lower and broader, and the successive phases of growth pattern (A, B, C - see above) are characterised by a gradual width increase in the $A$ phase (about 12 plates) and a long $B$ phase (10 plates).

Comparison with other species. Stramentum pulchellum is closest to $S$. praecursor sp.nov., from which it probably descended, and differs principally in the taller, narrower form of the fully-grown peduncle, the higher capitular 
angle $\left(110-125^{\circ}\right)$, the less acute rostral angle of the scutum, and the proportionately taller upper median and carinolatus. Stramentum pulchellum differs from $S$. inconstans in the lower carinolatus, the taller upper median latus, and in the shape of the scutum (less obtuse basilateral angle, more obtuse rostral angle). It differs from $S$. canadensis in the more obtuse umbonal angle of the scutum, the lower upper median and carinolatus, and the lower, broader peduncular plates.

Distribution. This species name has been used widely for diverse stramentid taxa, sometimes without regard to the detailed morphology (e.g., Breton \& Boiné 1993; Vega et al. 2007; Ifrim et al. 2011), and it is therefore necessary to assess records of the species in order to obtain an idea of its real geographical and stratigraphical distribution. Accepted occurrences are as follows:

- South-east England, 3 articulated specimens, from the lower Turonian Mammites nodosoides Zone at Cuxton, near Rochester, Kent. NHMUK In. 59150, In. 9130 (2 specimens). A single tergum from the upper Turonian Holaster planus Zone of Froxfield, Hampshire (Fig. 24O,P; SM 76163).

- Northern Ireland, a single specimen from the Turonian of Black Head Bay, Co. Antrim, Northern Ireland, the type of Loricula macadami Thomson, in MacAdam, 1858. Ulster Museum, Belfast, no. 1920-1.

- Czech Republic, Bohemian Cretaceous Basin, numerous localities, lower to upper Turonian; material figured originally by Fritsch \& Kafka (1887), some specimens of which were refigured by Kočova Veselská \& Kočí (2012) and Kočova Veselská et al. (2013). 8 specimens, National Museum Prague, NM 03445-9, 04255, 07132.

- Westphalia, north-west Germany; upper Cenomanian, Metoicoceras geslinianum Zone, to upper Turonian; see Schöllmann \& Hauschke (2012, table 1), approximately 60 specimens in various collections. 
Stramentum pulchellum is therefore restricted to northwest and central Europe (UK, northern Germany, Czech Republic) and ranges in age from the late Cenomanian Metoicoceras geslinianum Zone to the late Turonian Subprionocyclus neptuni Zone (approximately equivalent to the Holaster planus Zone of the UK zonation). The geographical restriction is perhaps surprising as the species is found attached to cosmopolitan ammonite species of genera such as Lewesiceras and Collignoniceras.

Stramentum canadensis (Whiteaves, 1889)

1889 Loricula canadensis Whiteaves; 190, pl. 26, fig. 4, 4a.

1935 Stramentum canadensis (Whiteaves); Withers: 319.

1977 Stramentum canadensis (Whiteaves); Hattin: 815, pl. 3, figs. 13, 14.

Type. The holotype is the individual figured by Whiteaves (1889) and Hattin (1977), from the Favel Formation, Turonian, on South Duck River, Manitoba, Canada, collected by J.B. Tyrrell (1887).

Material. Material from Kansas recorded by Hattin (1977) comes from the Pfeifer Member of the Greenhorn Limestone, and is of early Turonian age.

Diagnosis. Occludent margin moderately inflexed at level of upper latus; umbonal angle of scutum acute $\left(130^{\circ}\right)$, forming separate upper and lower occludent margins; umbonal position 3/10; basilateral angle of scutum $110^{\circ}$; upper latus, tergum and carinolatus proportionately tall; peduncular plates in paired columns more than three times wider than high.

Remarks. This species falls close to S. elegans, as noted by Hattin (1977: 817), who listed a number of differences between them. Probably the most important of these are in the shape of the scutum, which in S. canadensis has an obtuse, rather than right angled, basilateral angle, and an acute rostral angle. The latter feature does in fact change with ontogeny in S. elegans (compare Hattin 1977, pl. 1, figs 4-6). Additionally, the rostral articulation 
surface is absent in $S$. canadensis, and the peduncular plates in this species are broader and lower than in S. elegans. The other features noted by Hattin may be partly due to the rather poor preservation of the type specimen of $S$. canadensis. Hattin interpreted S. canadensis as ancestral to S. elegans, as it is known in Kansas from an older unit (Pfeifer Shale Member, lower Turonian), than that in which S. elegans occurs (Fairport Chalk Member, middle Turonian). According to W.J. Kennedy (pers. comm., June 2014) both units fall in the Collignoniceras woollgari Zone of the middle Turonian. In many respects (scutal shape, height/breadth ratio of peduncular plates, apical elongation of carinolatus, upper latus and tergum), S. canadensis is intermediate in morphology between S. pulchellum and S. elegans.

\section{Stramentum elegans Hattin, 1977}

Fig. 22

1977 Stramentum elegans Hattin; 807, pl. 1, figs. 4-6; pl. 2, figs. 1-12; pl. 3, figs. 1-12.

Holotype. A complete, fully-grown individual (Hattin 1977, pl. 1, fig. 4), KU 111520. Fairport Chalk Member, Carlile Shale, Ellis County, Kansas. Middle Turonian, Collignoniceras woollgari Zone. Paratypes from the same locality, KU 111521-111582, KU 111661, FH 8073A-J.

Diagnosis. Stramentum in which the occludent margin is strongly inflected at the apex of the median latus; carinolatus, tergum and upper latus tall and narrow; scutum trapezoidal, basilateral angle $90-100^{\circ}$, rostal angle $70-80^{\circ}$. Well-developed depressed articulation surface with rostrum. Peduncular plates twice wider than tall.

Remarks. This species is very distinctive, because of the tall, narrow carinolatus with a short basal margin (e.g., Fig. 22A-D), the tall tergum and upper latus, and the very trapezoidal appearance of the scutum in fully-grown individuals (Fig. $22 \mathrm{H}, \mathrm{J}$ ). However, there is considerable ontogenetic variation, and juveniles have lower rostral angles (e.g., Hattin 1977, pl. 1, fig. 5). Hattin 
(1977) figured beautifully preserved material from the Fairport Member, Carlile Shale of Kansas (middle Turonian, Collignoniceras woollgari Zone), a selection of which is re-illustrated here (Fig. 22).

Stramentum elegans evolved from the early Turonian S. canadensis (see discussion of S. canadensis above), and the distinctive morphology of the scutum allows one to infer that this species, or a closely related one, was ancestral to the late Turonian to Campanian Parastramentum gen. nov. The features include the nearly right-angled basitergal and rostral angles, the vertical rostral margin, and the well-demarcated rostral articulation surface on the scutum.

Mode of life. Stramentum elegans lived benthically, attached to Inoceramus and, more rarely, to ammonites (Hattin \& Hirt 1991).

Stramentum cf.elegans Hattin, 1977

p.2007 Stramentum pulchellum (G.B. Woodward); Vega et al.: fig. 5/1-3 only. p.2011 Stramentum pulchellum (G.B. Woodward); Ifrim et al.: fig. 5/9-11only.

Remarks. The small stramentids from the lower Coniacian of Mexico, attached to Forresteria, referred to S. pulchellum by Vega et al. (2007) and Ifrim et al. (2011), are close to S. elegans, on account of the inflected occludent margin and the tall, narrow carinolatus and tergum, and are here referred to $S$. cf. elegans.

Stramentum haworthi (Williston, 1896)

Figs. 19, 20

1896 Pollicipes haworthi Williston; 243, pl. 36.

1897 Stramentum haworthi (Williston); Logan: 188.

1897 Stramentum tabulatum Logan; 189. 
1898 Stramentum tabulatum Logan; 499.

v1920 Stramentum haworthi (Williston); Withers: 68, pl. 4, figs. 1-3.

v1935 Stramentum haworthi (Williston); Withers: 320, pl. 42, figs. 3-5.

Diagnosis. Occludent margin weakly inflexed at upper part of scutum, scutal umbo subcentral (6/10); apical quarter of lateral margin of scutum forming discrete, angled facet, and growth lines deflecting apically parallel to this; upper latus forms perfect isoceles triangle; tergum nearly an isoceles triangle, growth lines at occludent margin only deflect slightly apically.

Types. The original specimen of Williston is an individual (KU 8323) attached to an oyster (Withers 1935) from the Smokey Hill Chalk Member, Niobrara Chalk, near Gove City, Gove County, Kansas, which was refigured by Hattin (1977, pl. 1, fig. 1).

Material. The NHMUK collections contain an extensive suite of over 40 specimens of S. haworthi, purchased from H.T. Martin in 1900, from the Niobrara Chalk, horizon with Uintacrinus socialis (upper Santonian) of Elkader, Kansas. Some of these were figured by Withers $(1920,1935)$. Interestingly, all are attached to large, smooth baculitid ammonites (Fig. 20).

Comparison with other species. Stramentum haworthi is distinguished particularly by the form of the scutum, with a very low, subcentral umbo and a discrete apical lateral margin (Fig. 19A-D). The symmetrical upper latus and nearly symmetrical, low tergum are also characteristic. It most similar to $S$. pulchellum, but differs in details of shape of the capitular valves.

Remarks. The specimens of $S$. haworthi are all attached to the flanks of poorly preserved composite moulds of large, smooth baculitid ammonites (Fig. 20), as noted by Withers (1935). The most complete of these, NHMUK 18989 , is $240 \mathrm{~mm}$ in length and $40 \mathrm{~mm}$ in width. The cirripedes are concentrated close to the mid-line of the ammonite flanks, and none are present towards the dorsal or ventral margins. 18 individuals are present on NHMUK In.18989, the longest section (Fig. 20). They vary from complete articulated individuals 
(e.g., Fig. 19) to variably disarticulated ones. Although a few display similar orientation (e.g., Fig. 19B), there does not appear to be a consistent pattern, and it is not clear from the relatively short lengths of baculitids preserved which end was proximal and which distal. There are unfortunately no counterparts present in the collection. There are two preservational modes; in the rarer one, the peduncular plates of both sides of the cirripedes are preserved (e.g., Fig. 19C), and in the other the capitular plates of both sides are present, but the interior of the peduncular plates of a single side are exposed.

Two lines of evidence allow the inference to be made that the cirripedes were attached in life to the ammonites. The preferred attachment sites close to the mid-flank of all specimens is suggestive of site selection by settling cyprid larvae. Secondly, it is probable that both sides of the baculitids were colonised, but this is impossible to demonstrate certainly without any counterparts.

The occurrence of an individual of $S$. pulchellum attached to a specimen of Sciponoceras from the Turonian of the Teutoburgerwald, northwest Germany, was described by Hauschke et al. (2013). This is found on the inferred ventral margin of the ammonite, and the orientation of the occludent surface having been towards the aperture of the ammonite.

Stramentum inconstans Collins, 1986

Fig. 18A, C-G

1986 Stramentum inconstans Collins; 125, figs. 1-4.

Types. The largely complete individual figured by Collins (1986, figs. 1,4) NHMUK In. 62053. There are also 8 paratypes, NHMUK In. 62454-62061. Lower Turonian of the Eze-Aku Formation of Lokpanta, eastern Nigeria, which has yielded a diverse assemblage of ammonites indicative of the Mammites nodosoides Zone. 
Diagnosis. Rostral margin of capitulum more strongly convex than carinal margin. Scutum trapezoidal, with acute rostral angle $\left(45^{\circ}\right)$ and oblique basal lateral angle $\left(150^{\circ}\right)$; apex acuminate, and a ridge and shallow furrow run from the umbo to the tip of the apex. Upper latus low and broad. Growth lines on tergum deflected towards apex adjacent to occludent margin. Carinolatus narrow and tall.

Remarks. This species is closest to S. pulchellum in the morphology of the capitular plates, particularly in the shape of the tergum. The low scutum, with an acute rostral angle and obtuse basilateral angle, is very similar to that of $S$. praecursor sp. nov. The species differs from S. pulchellum in the lower scutum, the broad upper latus, and the tall, short carinolatus. Additionally, the peduncular plates in the apical portion of the rostral column possess a carinally directed process which intercalates with the plates of the scutal column (Fig. 18D). This is absent in S. pulchellum and S. praecursor (Fig. 16). The species probably evolved from S. praecursor sp. nov., with which it shares a low scutum and upper latus. The variation in the form of the upperlatus column of peduncular plates noted by Collins (1986), appears to be a taphonomic artefact caused by variable post mortem flexion of the peduncle. In some individuals, this resulted in increased imbrication of the plates (e.g., Fig. 18G) such that they appear to be very broad and low.

\section{Stramentum cf. inconstans Collins 1986}

Fig. 25E-I, L, M, Q, R

Material. 8 capitular valves, and numerous peduncular plates ( $>25)$ from the lower Turonian Mammites nodosoides Zone, escarpment $3 \mathrm{~km}$ northeast of the village of Asfla, $30 \mathrm{~km}$ north of Goulmima, Morocco (Kennedy et al. 2008). The material came from the level between 20 and $23 \mathrm{~m}$ (see Kennedy et al. 2008, fig. 2). NHMUK IC 1258-1266.

Description. Two incomplete scuta are present in the material (Fig. 25E); these have an acute rostral angle $\left(40^{\circ}\right)$, and distinctive low triangular depression for articulation of the rostrum. The shape of the rostrum is closely 
comparable with that of the type of $S$. inconstans, but the Nigerian material lacks any specialised rostral surface. The upper latus (Fig. 25I) is low, triangular and the basal scutal angle is low $\left(50^{\circ}\right)$. Both shape and angles are closely comparable to those in S. inconstans. The tergum has the form of a low isoceles triangle, with a long, straight, bevelled margin for contact with the carinolatus, and a weakly convex occludent margin (Fig. 25F, Q, R). The growth lines deflect apically at the occludent margin. The carinolatus is tall with a short basal margin and an acute apical angle; the carinal margin is gently concave, the tergal margin convex (Fig. 25G). The shape is very similar to that of type material of $S$. inconstans refigured here (Fig.18A, E, F, G).

Remarks. The morphology of the isolated valves permits detailed comparison with the Nigerian material. The only significant difference is the presence of a defined rostral articulation surface on the scutum in the Moroccan material, absent in the Nigerian types. The presence of a form close to $S$. inconstans in southern Morocco is interesting, because it provides further evidence of provinciality in the distribution of stramentids, the African records both representing occurrences on the southern side of the Tethys Ocean.

\section{Stramentum alekseevi sp. nov.}

Fig. 28A, B

2009 Loriculina laevissima (Zittel); Alekseev; fig. 4/22a, b.

Type material. The scutum figured by Alekseev (2009), upper Turonian, Locality 10, Mangyshlak Peninsula, Kazakhstan. Moscow State University collections, no. $270 / 22$.

Diagnosis. Stramentum in which the scutal umbo is positioned high on the occludent margin; the lateral and rostral surfaces are depressed, and the scutal adductor scar is deep and high in position.

Description. Scutum triangular, occludent margin long and convex.Rostral angle acute $\left(60^{\circ}\right)$, basilateral angle obtuse $\left(110^{\circ}\right)$. Umbo subapical $(2 / 10)$ and 
very high. Rostral surface very broad and tall. A depressed triangular zone adjacent to the upper lateral margin extends from the basilateral angle to the umbo. Distinct growth banding is present on the exterior of the valve. On the interior of the valve, the scutal adductor scar is high and deep, with no supraadductor shelf.

Remarks. This form is referred to Stramentum with some uncertainty, because the high scutal umbo and the deep, very high position of the scutal adductor are not typical of the genus. However, it shows an overall similariy with $S$. elegans, in the development of depressed lateral and rostral surfaces (compare Fig. $22 \mathrm{H}, \mathrm{J}$ ), and in the shape of the scutum of immature $\mathrm{S}$. elegans (Fig. 22A).

Genus Parastramentum gen. nov.

Type species. Parastramentum peakei sp. nov.

Diagnosis. Body asymmetrical, inclined towards rostral side; peduncular plates angled to mid line, scutal and carinolatus columns differ in shape and orientation; scutum rhombic, umbo central, or slightly subcentral; sharply demarcated, inset, triangular rostral articulation surface; angle between occludent and rostral margins obtuse, $120-130^{\circ}$; tergum triangular, elongated, occludent surface inwardly curved, angled to rest of valve.

Derivation of name. From the Sanskrit para, meaning beyond, the genus having presumably evolved from Stramentum.

Included species. Loricula expansa Withers, 1911, Parastramentum peakei sp. nov., $P$. albertaensis sp. nov. and $P$. brydonei sp. nov.

Remarks. Parastramentum gen. nov. is consistently distinguished from Stramentum by the morphology of the scuta, terga and peduncular plates. In Stramentum, the tergum has a flat interior surface, and the outline is triangular 
with gently convex margins (Figs. 24O, P, 25F, Q, R). In Parastramentum gen. nov., the valve is strongly inflexed parallel with the occludent margin, and a separate occludent surface is bent towards the opposing tergum (Figs. 23G, $\mathrm{H}, \mathrm{L}, \mathrm{P}, 24 \mathrm{~K}, \mathrm{~L})$. The contact with the carinolatus is straight. The scuta are characterised by the fact that the lateral and rostral margins are set at about $90^{\circ}$ to the basal margin, the downward inflexion of growth lines close to the upper occludent margin; the approximately central scutal umbo; the presence of a well-defined inset facet for articulation of the rostrum (Figs. 23M-O, 24A$H)$.

The form of the body is known from two articulated specimens, one from the Bearpaw Formation (Campanian) of Alberta, Canada, here described as $P$. albertaensis sp. nov. (Fig. 28D, E), and an individual of $P$. peakei sp. nov. lacking the capitulum, from the upper Campanian Chalk of Norwich, UK, preserved on the basal attachment surface of an oyster (Fig. 28 A,B; NHMUK 42012). The peduncle is asymmetrically inclined towards the rostral side (Fig. $28 \mathrm{~A}, \mathrm{~B}, \mathrm{~F}, \mathrm{G})$, and the carinolatus and scutal column plates are very different in shape, the carinolatus column being angled to the upper latus column (Fig. 28 A,B,F,G; compare with Stramentum in Fig. 16).

The distinctive scutal morphology of Parastramentum gen. nov. is foreshadowed in that of Stramentum elegans, in which the basal and lateral margins are nearly at right angles, and a distinct rostral articular surface (rostral slip of Hattin 1977) for the rostrum is present (Fig. 22C, H, J). However, the tergum of $S$. elegans is typical of Stramentum as it is triangular to rhombic and flat. It is likely that Parastramentum gen. nov. evolved from $S$. elegans or a species close to it in the middle Turonian. Terga of Parastramentum gen. nov. are present in upper Turonian chalks in the UK, alongside those of typical S. pulchellum. Parastramentum gen. nov. is locally abundant in upper Campanian Chalk in the UK.

Parastramentum peakei sp. nov.

Figs. 23E, M, 24A-N, 25 A,B 
Types. The scutum figured herein (Fig. 24A) from the Belemnitella mucronata Zone, Echinocorys subconicula horizon (see Wood 1988) of Newfound Farm Pit, Cringleford, Norwich, UK (ASG sample no. CR1) is holotype (NHMUK IC 1238). The other plates figured from the same locality are paratypes (NHMUK IC 1234, 1239-1258).

Diagnosis. Parastramentum in which the scutum possesses a large triangular, inset, rostral articulation surface. The tergum has an elongated apical region, and the basal angle is not rounded.

Material. Over 300 isolated plates from the upper Campanian Belemnitella mucronata Zone of Norwich, Norfolk, UK; Cringleford, Newfound Farm Pit, Keswick and Catton Grove (Wood 1988). The articulated individual figured by Jagt (2013, Fig. 17) is from the Campanian of Hannover, Germany; private coll. of W. Dembski, Ahlten.

Derivation of name. In honour of the late Norman Peake, expert on the Chalk of Norfolk, and coauthor of 'The Upper Cretaceous of Norfolk' (Peake \& Hancock 1961), an important paper.

Description. The scuta (Fig. 24A-H) are asymmetrically rhomboidal in outline, and the basilateral angle approximates to $90^{\circ}$ in most specimens, but more rarely is up to $110^{\circ}$ (Fig. 24G). The primordial valve (Fig. 24F) is very elongated and triangular, and forms a distinct prominence on the occludent surface (e.g., Fig. 24A, B, G). The occludent angle is obtuse, from $140^{\circ}-160^{\circ}$, and the umbo is central in position. A well-demarcated, triangular rostral articulation extends from just beneath the umbo to the basal margin, and is inset beneath the rest of the valve's surface. A poorly defined ridge extends from the umbo to the basilateral margin, better defined in larger valves (Fig. $24 \mathrm{H}$ ). The apical angle is acute $\left(50-60^{\circ}\right)$, and a raised area extending from the umbo to the top of the upper lateral margin, well-developed in $P$. expansum (Fig. 23N, O) is weakly developed (Fig. 24A) or absent. On the interior of the valve, the scutal adductor scar is slightly subcentral (Fig. $24 \mathrm{C}$, 
D). The terga (Figs. 23E, 24K, L) approximate in outline to a right triangle, with the upper latus and occludent margins subtending an angle of $90-100^{\circ}$ and an acute apical angle. A well-defined, inflexed occludent surface is present on which the growth lines swing sharply towards the apex. The upper latus is flat (Fig. $24 \mathrm{M}, \mathrm{N}$ ), has a slightly asymmetrical triangular outline, with significant overlap of the tergum and scutum. The carinolatus (Fig. 24I, J) has the outline of an isosceles triangle, of which the rostral margin is the longest, and the basal and carinal margins are subequal in length. On the interior, adjacent to the carinal margin, a flange extends from the apex to just above the carinobasal angle, which presumably articulated with the carina.

The peduncular scales (Figs. 25A-D, J, K, N-P, 27) include rectangular carinal and rostral rows (Fig. 25J, K, O, N), often with an extension on the carinolatus side (e.g., Fig. 250). Plates of the scutal column (Fig. 25C) are low and broad, and have a blunt termination against the carinal column, and an interdigitation with the upper latus column (Fig. 27). Plates of the central upper latus column (Fig. 25A, D) are distinctly asymmetrical, and have lateral processes which interdigitate with both the carinolatus and scutal columns (Fig. 27). The carinolatus column (Fig. 25B) tapers very markedy from a tall blunt rostral margin towards the upper latus column. The reconstruction (Fig. 27) gives an impression of the form of the peduncular construction, aided by the type specimen of $P$. albertaensis sp. nov. (Fig. 28D, E) which clearly demonstrates the asymmetry between scutal and carinolatus columns characteristic of Parastramentum gen. nov.

Remarks. Parastramentum peakei sp. nov. differs from $P$. expansum in the better-developed, inset scutal articulation, and the absence of or very weak development of a ridge on the upper occludent margin. From $P$. brydonei sp. nov., it differs in the more acute basal angle, and narrower basal portion of the valve.

Parastramentum expansum (Withers, 1911)

Fig. 23N-P 
v1911 Loricula expansa Withers; 27, fig. 8a, b.

1920 Stramentum expansum Withers, p. 70.

p.1935 Stramentum expansum (Withers); Withers: 321, pl. 39, fig. 9.

vp.1935 Loriculina laevissima (von Zittel); Withers: 305, pl. 40, fig.13 only.

Types. The scutum from the 'Actinocamax quadratus' Zone (probably either upper Offaster pilula or basal Gonioteuthis quadrata zones, lower Campanian) of East Harnham, near Salisbury, Wiltshire, UK, is holotype (NHMUK In.13812). Three other scuta from the same locality are paratypes (NHMUK In. 30524-6).

Other material. The more completely known $P$. peakei sp. nov. allows assignation of a tergum from East Harnham, identified and figured by Withers (1935: 305, pl. 40, fig.13) as belonging to Loriculina laevissima to be correctly assigned to this species (see above). Of the other material assigned by Withers to S. expansum, the scutum from Norwich listed (NHMUK In. 27275) is here assigned to $P$. peakei sp. nov.

Diagnosis. Parastramentum in which the scutum bears a slightly raised, flattopped and sharply defined triangular ridge running from the umbo to the upper part of thelateral margin. Rostral articulation surface weakly developed.Tergum subtriangular, apex short, with broad to rounded basal angle.

Description. The four available scuta are large, have a trapezoidal outline, and the rostral and lateral margins are subparallel (Fig. 23N,O). The lateral and basal margins are set at right angles, and the umbones are central to slightly subcentral (5-6/10). The umbonal angle is $135-150^{\circ}$, and the apical angle is $50-60^{\circ}$; a slightly raised, flat-topped and sharply defined triangular area runs from adjacent to the umbo to the top of the lateral margin, on which the growth lines are slightly deflected away from the apex. A poorly defined low crest runs from the umbo to the basal angle, on which the growth lines deflect at $90^{\circ}$. The rostral articulation surface is poorly defined. The single large, damaged tergum (Fig. 23P) is markedly concavo-convex, subtriangular, 
and the part of the valve adjacent to the occludent margin is bent towards the opposing tergum. On this area, the growth lines are inflected towards the apex of the valve. The occludent margin is shorter than the lateral margin, and the carinolateral margin is long and straight. The basal part of the lateral margin forms a short separate margin, set at $90^{\circ}$ to the occludent margin.

Discussion. Parastramentum expansum differs from the late Campanian $P$. peakei sp. nov. in a number of features. On the scutum of the latter the ridge running from the basal angle to the umbo is poorly defined or absent, and the flat, raised area adjacent to the upper part of the occludent margin is absent or poorly defined. The rostral articulation is well defined and inset in $P$. peakei sp. nov. The terga differ in that the occludent margin of $P$. peakei is proportionately shorter, and the basal tergal angle is not truncated by a short separate margin.

It is noteworthy that Withers (1935: 322) was not certain of the stramentid affinities of $P$. expansum, stating that, 'The possibility is not excluded that it may represent a varietal form of Zeugmatolepas cretae.' Similarities between zeugmatolepadid and stramentid scuta can now be shown to be convergent.

\section{Parastramentum albertaensis sp. nov.}

Fig. 28D, E

Holotype. A large individual attached to an ammonite, Placenticeras.

Campanian, Rusty Pimm Ammolite Mine, Lethbridge, Alberta, Canada. Royal Tyrrell Museum, Drumheller, Canada, TMP 2009.056.0004.

Diagnosis. Parastramentum in which the basal angle of the scutum is well rounded, and the scutal umbo is subcentral.

Derivation of name. For the State of Alberta, Canada, where the unique specimen was found. 
Description. The single large (35 $\mathrm{mm}$ length) and mature individual is articulated, but the capitular plates are somewhat damaged, and the boundaries of the tergum, carinolatus and upper latus can only be inferred. The scutum is rhombic, and the basilateral angle is about $90^{\circ}$, but is distinctly rounded. The upper latus is a nearly symmetrical isosceles triangle; the tergum has a similar shape, and the carinolatus has an elongated basal margin, and a long, slightly curved contact with the tergum. The peduncular plates are exceptionally well preserved, and about 24 rows are present. There is marked asymmetry between the scutal and carinolatus rows; the former are relatively tall at the rostral margin and taper to the interdigitating contact with the upper latus column; they are set obliquely to the axis. The carinolatus plates are of more even height, and not obliquely set. There are well-marked A-C ontogenetic stages, with about 10 plates in the A stage, 8 in the B stage, and 7 in the $C$ stage. The $C$ stage plates become progressively lower in height towards the capitulum, and are slanted towards the rostral side.

Remarks. The species is referred to Parastramentum gen. nov. on the shape of the scutum, which has a right-angled basilateral angle, and most particularly on account of the shapes of the peduncular plates which can be compared in detail with those of $P$. peakei sp. nov. The species differs from congeners in the shape of the scutum, with its rounded basilateral angle and low umbo.

Parastramentum brydonei sp. nov.

Fig. 23G, $\mathrm{H}$

p.1935 Loriculina laevissima (von Zittel); Withers: pl. 40, figs. 8, 9 only.

Types. The holotype is a well-preserved tergum from Froxfield (see below), SM 76166. The 2 terga in the NHMUK (In.32485-6) from the same locality are paratypes. 
Material. Six terga from the upper Turonian Holaster planus Zone chalk of Froxfield, Pit no. 125 of Brydone (1912), close to junction of Barnet Side Lane and King's Lane, Froxfield, $5 \mathrm{~km}$ northwest of Petersfield, Hampshire. SU 704275, collected by R.M. Brydone.

Description. The terga have the form of acute isoceles triangles, in which the longest side is formed by the straight carinolateral margin, and the slightly convex occludent and lateral margins are equal in length. The part of the valve adjacent to the occludent margin is curved towards the opposing tergum, and the growth lines on this surface are deflected apically. The apex is abraded. The basal angle of the tergum is broad and rounded

Discussion. Withers (1935) identifed these plates as terga of Loriculina, but the discovery of well-preserved Loriculina individuals shows that they cannot belong to that genus. The terga from Froxfield can be confidently assigned to Parastramentum gen. nov. from the elongated triangular shape, and the inturned occludent part of the valve. They are comparable with $P$. peakei sp. nov. in the degree of elongation of the valves, and the acute apical angle, but differ importantly in the more rounded, broader basal angle (compare Fig. 23G, $\mathrm{H}$ with Fig. 24K, L). The occurrence is of importance in that it demonstrates that Parastramentum gen. nov. had evolved by the late Turonian, and co-existed with typical Stramentum pulchellum.

\section{Acknowledgements}

Numerous people have assisted in this project, in various ways. I like to thank Don Hattin for providing me with the original negatives of illustrations from his 1977 paper, permitting refiguring of the beautiful original material of Stramentum elegans and Angulatergum moorei. In the Texas Memorial Museum (Austin), Ann Molineaux and Angie Thomson kindly took photos of Withers's type of Loriculina texana. Christina Ifrim (Heidelberg) kindly sent me the important specimen of Peroniceras from Mexico which proved to be so 
important for the study of the Stramentidae. The NHM Photographic Unit provided some excellent images, for which I am very grateful. Claire Mellish permitted access to NHM specimens, and Ken McNamara to the Sedgwick Museum material. John Cooper of the Booth Museum, Brighton, kindly lent me the paratype specimen of Stramentum praecursor sp. nov. in their collections and allowed me to prepare it. I also thank Günter Schweigert (Stuttgart) for kindly providing photos of Archaeolepas and Eolepas. Aleksandr Alekseev (Moscow) sent me photographs of the type of $S$. alekseevi sp. nov. I am also exceedingly grateful to Simon Cragg and Christine Hughes for allowing me extensive use of the excellent SEM in Biological Sciences, University of Portsmouth. I would like to thank the reviewers, John Jagt and John Buckeridge for most helpful reports.

\section{References}

Alekseev, A.S. 2009. Usonogie raki (Cirripedia, Thoracica) verkhnego mela Mangyshlaka. Byulleten' Moskovskogo Obshchestva Ispytatelej Prirody, Otdel Geologicheskij 84, 23-38.

Anderson, D.T. 1994. Barnacles: structure, function, development and evolution. Chapman \& Hall, London, 357 pp.

Breton, G. and Boiné, G. 1993. Cinq Stramentum pulchellum (G.B. Sowerby, 1843), cirripèdes pédonculés fixés sur une ammonite du Cénomanien Moyen de Haute Normandie (France). Bulletin trimestriel de la Société géologique de Normandie et des Amis du Muséum de Havre 80, $19-25$.

Broch, H. 1922. Papers from Dr. Th. Mortensen's Pacific Expedition, 1914-16. No. 10. Studies on Pacific Cirripeds. Videnskabelige Meddelelser fra det Dansk Naturhistorisk Forening 73, 215 -358.

Brydone, R.M. 1912. The Stratigraphy of the Chalk of Hants. Dulau and Co., London. 116 pp.

Buckeridge, J.S. 1983. Fossil barnacles (Cirripedia: Thoracica) of New Zealand and Australia. New Zealand Geological Survey, Paleontological Bulletin 50, 1-151, 13 pls. 
Buckeridge, J.S. \& Grant-Mackie, J.A. 1985. A new scalpellid barnacle (Cirripedia: Thoracica) from the Lower Jurassic of New Caledonia. Géologie de la France 1, 77-80.

Buckeridge, J.S. \& Newman, W.A. 2006. A revision of the Iblidae and the stalked barnacles (Crustacea: Cirripedia: Thoracica), including new ordinal, familial and generic taxa, and two new species from New Zealand and Tasmanian waters. Zootaxa 1136, 1-38.

Bourguet, E. 1987. Barnacle shells: composition, structure and growth. In: Southward, A.J. (ed.), Barnacle biology. Crustacean Issues, 5, 267285. A.A. Balkema, Rotterdam.

Chernyshev, B.I. 1930. Cirripeden aus dem Bassin des Donez und Kusnetzk. Zoologischer Anzeiger 92, 26-28.

Collins, J.S.H. 1986. A new Stramentum (Cirripedia) from the Lower Turonian of Nigeria. Bulletin of the British Museum of Natural History (Geology) 40, 125-131.

Dames, W. 1878. Über eine neue Art der Cirripeden-Gattung Loricula aus den Kreideablagerungen des Libanon. Sitzungsberichte der Gesellschaft der naturforschenden Freunde zu Berlin 1878, 70-74.

Dames, W. 1885. Über Loriculina Noetlingi nov. spec. von Sahel Alma vom Libanon. Sitzungsberichte der Gesellschaft der naturforschenden Freunde zu Berlin 1885(8), 151-155.

Darwin, C.R. 1851a. A monograph on the fossil Lepadidae, or pedunculated cirripedes of Great Britain. Monograph of the Palaeontographical Society London 1851, vi $+88 \mathrm{pp}$.

Darwin, C.R., 1851b. A monograph on the sub-class Cirripedia, with figures of all the species. The Lepadidae, or pedunculated crripedes. The Ray Society, London. xii + 400 pp., 10 pls.

Davadie, C. and Emberger, J. 1955. Découverte d'une nouvelle espece de Stramentum (Loricula) dans l'Albien supérieur de Bou-Saada. Publication du Service de la Carte géologique d'Algérie (Nouvelle Série) 5, 403-417.

Drushchits, V.V. and Zevina, G.B. 1969. New Lower Cretaceous cirripeds from the northern Caucasus. Paleontological Journal 2, 214-224. 
Ejel, F. and Dubertret, L. 1966. Sur l'âge précis du gisement du poisons et Crustacés crétacés de Sahel Alma, Liban. Comptes Rendus sommaires des Séances de la Société Géologique de France 1966(9), 353-354.

Fritsch, A. 1878.Studien im Gebiete der Böhmischen Kreideformation. 2. Die Wissenberger und Malnitzer Schichten. Archiv für naturwissenschaftliche Landesdurchforschung von Böhmen 4, 153 pp.

Fritsch, A. and Kafka, J. 1887. Die Crustaceen der Böhmischen Kreideformation, 53 pp. Selbstverlag, in Commission von Fr. Řivnáč, Praha.

Gale, A.S. 1995. Cyclostratigraphy and correlation of the Cenomanian of Europe. In House, M.R. and Gale, A.S. (eds.), Orbital forcing time scales and cyclostratigraphy. Geological Society Special Publication 85, 177-197.

Gale, A.S. 2014a. New thoracican cirripedes (Crustacea) from the Jurassic and Cretaceous of the UK. Proceedings of the Geologists' Association $125,406-418$.

Gale, A.S. 2014b. Origin and evolution of the verrucomorph thoracicans (Crustacea, Cirripedia).Journal of Systematic Palaeontology http://dx.doi.org/10.1080/14772019.2014.954409

Gale, A.S. and Sørensen, A.M. 2014. Origin of the balanomorph barnacles new evidence from the Cretaceous of Sweden.Journal of Systematic Palaeontology http://dx.doi.org/10.1080/14772019.2014.954824

Gale, A.S. and Sørensen, A.M. 2015. Cirripedes from a Cretaceous rocky shoreline at Ivö Klack, southern Sweden. Cretaceous Research http://dx.doi.org/10.1016/j.cretres.2014.09.004

Geinitz, H.B. 1875. Der untere Quader. Palaeontographica 20 (1), 288-9.

Harbort, E. 1905. Die Fauna der Schaumburg-Lippe'schen Kreidemulde. Abhandlungen der Preussischen Geologischen Landesanstalt 45, 112 pp., 12 pls.

Hattin, D.E. 1977. Articulated lepadomorph cirripeds from the Upper Cretaceous of Kansas: Family Stramentidae. Journal of Paleontology 51, 797-825. 
Hattin, D.E. and Hirt, D.S. 1991. Paleoecology of scalpellomorph cirripedes in the Fairport Member, Carlile Shale (Middle Turonian) of central Kansas. Palaios 6, 553-563.

Hauschke, N. 1994. Lepadomorphe Cirripedier (Crustacea, Thoracica) aus dem höchsten Cenoman des nördlichen Westfalen (Nordwestdeutschland), mit Bemerkungen zur Verbreitung, Palökologie und Taphonomie der Stramentiden. Geologie und Paläontologie in Westfalen 32, 5-39.

Hauschke, N., Schöllmann, L. and Keupp, H. 2011. Oriented attachment of a stalked cirripede on an orthoconic heteromorph ammonite implications for the swimming position of the latter. Neues Jarbuch für Geologie und Paläontologie Abhandlungen 262, 199-212.

Høeg, J.T., Whyte, M.A., Glenner, H. and Schram, F.R. 1999. New evidence on the basic phylogeny of the Cirripedia Thoracica. In Schram, F.R. and von Vaupel Klein, J.C. (eds), Crustaceans and the Biodiversity Crisis, Proceedings of the Fourth International Crustacean Congress, 1998, 100-114. Koninklijke Brill NV, Leiden.

Ifrim, C., Vega, F.J. and Stinnesbeck, W. 2011. Epizoic stramentid cirripedes on ammonites from Late Cretaceous platy limestones in Mexico. Journal of Paleontology 85, 524-536.

Jagt, J.W.M., 2013. Rankenfußkrebse (Cirripedia). In: Schneider, C. (ed.). Fossilien aus dem Campan von Hannover (3., komplett überarbeitete Auflage): 248-253, 17 figs. Arbeitskreis Paläontologie Hannover, Hannover.

Jagt, J.W.M. and Collins, J.S.H. 1989. Upper Cretaceous cirripedes from N.E. Belgium. Proceedings of the Geologists' Association 100, 183183-192.

Kennedy, W.J. and Cobban, W.A. 1976. Aspects of ammonite biology, biogeography and biostratigraphy.Special Papers in Palaeontology 17, $1-94$.

Kennedy, W.J. and Gale, A.S. In press. Monograph of the Ammonoidea of the Lower Chalk. Final part, Conclusions. Monograph of the Palaeontographical Society London. 
Kennedy, W.J., Gale, A.S., Ward, D.J. \& Underwood, C. 2008. Lower Turonian ammonites from Goulemima, Morocco. In Steurbaut, E., Jagt, J.W.M. and Jagt-Yazykova, E.A. (eds). Annie V. Dhondt Memorial Volume. Bulletin de l'Institut royal des Sciences naturelles de Belgique, Sciences de la Terre 78,149-177.

Kennedy, W.J. and Kaplan, U. 1995. Parapuzosia (Parapuzosia) seppenradensis (Landois) und die Ammonitenfaunen der Dülmener Schichten, unteres Unter-Campan, Westfalen. Geologie und Palaöntologie in Westfalen 33, 1-127

Kočí, T., Kočova Veselská, Gale, A.S., Jagt, J.W.M. and Skupien, P. 2015. Late Jurassic-Early Cretaceous stalked barnacles (Cirripedia, genus Eolepas Withers, 1928) from Štramberk, Moravia (Czech Republic). Neues Jahrbuch für Geologie und Paläontologie Abhandlungen 275, 233-247.

Kočova Veselská, M. and Kočí, T. 2012. Preliminary revision of genus Stramentum Logan, 1897 (Cirripedia, Stramentidae) from the Bohemian Cretaceous Basin. Geoscience Research Reports for 2011, Praha, pp. 132- 134 (in Czech with English abstract).

Kočova Veselská, M., Kočí, T. and Buckeridge, J.S. 2013. A systematic revision of Stramentum (Stramentum) pulchellum (G.B. Sowerby Jr, 1843) from the Bohemian Cretaceous Basin, the Czech Republic. Acta Musei Nationalis Pragae, Series B, Historia Naturalis 69, 151-158.

Logan, W.N. 1897. Some new cirriped crustaceans from the Niobrara Cretaceous of Kansas. Kansas University Quarterly, 6, 187-189.

Loriol, P. de and Pellat, E., 1867. Monographie paléontologique et géologique de l'étage Portlandien des environs de Boulogne-sur-Mer. Mémoires de la Société de Physique et d'Histoire naturelle de Genève 19, 1-200, 11 pls.

Loriol, P. de, Royer, E. and Tombeck, H. 1872. Monographie paléontologique et géologique des étages supérieurs de la formation Jurassique du départment de la Haute Marne. Memoires de la Société Linnéenne de Normandie 16, 542 pp. 
Lowenstam, H.A. and Weiner, S. 1992. Phosphatic shell plates of the barnacle Ibla (Cirripedia): a bone-like structure. Proceedings of the National Academy of Sciences USA 89, 10573-10577.

Lowenstam, H.A., Weiner, S. and Newman, W.A. 1992. Carbonate apatite containing plates of a barnacle (Cirripedia). In Slavkin, H. and Price, P. (eds), Chemistry and biology of mineralised tissues. Elsevier, Amsterdam, pp. 73-84.

McNamara, K. 1995. Evolutionary change and heterochrony. John Wiley and Sons, New York, 286pp.

Moore, C. 1861. On the Zones of the Lower Lias, and the Avicula contorta Zone. Quarterly Journal of the Geological Society London18, 483-516, pls $15,16$.

Morris, J. 1845. On the occurrence of the genus Pollicipes in the Oxford Clay. Annals and Magazine of Natural History (1)15, 30-31.

Newman, W.A. 1979. A new scalpellid (Cirripedia); a Mesozoic relic found living in an abyssal hydrothermal spring.Transactions of the San Diego Society of Natural History 19, 153-167.

Newman, W.A.1987. Evolution of cirripedes and their major groups. In Southward, A.J. (ed.), Barnacgy. Crustacean Issues 5, 3-43. A.A. Balkema, Rotterdam.

Newman, W.A. \& Ross, A. 1998. Peduncular armament in the Scalpellomorpha (Cirripedia) and a new abyssal species from the East Pacific Rise. Journal of Crustacean Biology 18, 572-580.

Newman, W.A., Zullo, V.A. and Withers, T.H. 1969. Cirripedia. In Moore, R.C. (ed.), Treatise on Invertebrate Paleontology, Part R, Arthropoda 4(1): R206-R295. The University of Kansas and The Geological Society of America Inc.

Nomura, S.-I., Maeda, H., Harada, S. and Tanaka, G. 2006. First record of the cirripede genus Stramentum (Thoracica, Scalpelliformes) from the Upper Cretaceous of Japan. Palaeontology 52, 849-855.

Oekentorp, C. 1989. Paläontologische Besonderheiten aus der Westfälischen Kreide. 1. Stramentum pulchellum (Sowerby, 1843), ein Cirripedier (Arthropoda, Crustacea) aus dem Turon von Bochum. 
Münstersche Forschungen zur Geologie und Paläontologie 69, 128153.

Oppel, A. 1862. Über jurassische Crustaceen. Paläontologische Mitteilungen des Museums des Bayerischen Staates 1, 1-120, pls 1-38.

Peake, N.B. and Hancock, J.M. 1961. The Upper Cretaceous of Norfolk. Transactions of the Norfolk and Norwich Naturalists' Society 19, 293-339.

Pérez-Losada, M., Harp, M., Høeg, J.T., Achituv, Y., Jones, D., Watanabe, H. \& Crandall, K.A. 2008. The tempo and mode of barnacle evolution. Molecular Phylogenetics and Evolution 46, 328-346.

Richardson, L. 1908.On a new species of Pollicipes from the Inferior Oolite of the Cotteswold Hills. Geological Magazine (5)5, 351-352.

Reid, D.G., Mason, W.J., Chan, B.K.K. and Duer, M.J. 2012. Characterization of the phosphatic mineral of the barnacle Ibla cumingi at atomic level by solid-state nuclear magnetic resonance: comparison with other phosphatic biominerals. Journal of the Royal Society Interface 9, 1510-1516.

Royo y Gomez, J. 1941.Crustáceos y Seudoterépodos del Cretácico de Colombia. Boletin de Minas y Petroléos, Bogota 1941, 121-144, 209214.

Schöllmann, L. and Hauschke, N. 2012. Fossilerhaltung und Taphonomie von Stramentum (Stramentum) pulchellum (Sowerby, 1843) (Crustacea: Stramentidae) aus dem Unterturon des Teutoburger Waldes (Nordrhein-Westfalen, Deutschland). Geologie und Paläontologie in Westfalen 84, 55-77.

Schweigert, G. 2014. Darwin's Liebelinge - Rankenfusskrebse. Fossilien 2014/3, 36-41.

Seguenza, G, 1876. Ricerche palaeontologiche intorno al Cirripedi Terziarii della provincia di Messina. Parte II. Terza famiglia Lepadi Darwin. Atti dell'Accademica Pontoniana 10, 112 pp.

Smith, A.B. 1994. Systematics and the fossil record: documenting evolutionary patterns. Blackwell Scientific Publications, Oxford, 223 pp. 
Sowerby, G.B. Jr. 1843. Description of a new Fossil Cirripede from the Upper Chalk near Rochester. Annals and Magazine of Natural History (1)12, 260-261.

Steenstrup, J. 1839. Bidrag til Cirripedernes Historie i Fortid og Nutid. Forste Bidrag. Anatiferidae og Pollicipedidae fra Kritperioden. Krøyer's Naturhistorisk Tidsskrift 11, 396-415.

Thomson, W. 1858. Description of the fossil.In MacAdam, J. On a new fossil cirripede. Annals and Magazine of Natural History (3)1, 321-325.

Vega, F.J., Nyborg, T., Rojas-Briceño, A. Patarroyo,P., Luque, J., PorrasMúzquiz, H. and Stinnesbeck, W. 2007. Upper Cretaceous Crustacea from Mexico and Colombia: similar faunas and environments during Turonian times. Revista Mexicana de Ciencas Geológicas 24, 403-422.

Villamil, T. and Arango, C. 1998. Integated stratigraphy of latest Cenomanian and early Turonian of Colombia. In Pindell, J.L. and Drake, C.L. (eds). Paleogeographic evolution and non-glacial eustasy, northern South America. Society of Economic Paleontologists and Mineralogists, Special Publication 58, 129-159.

Whiteaves, J.F. 1889. On some Cretaceous fossils from British Columbia, the North West Territory and Manitoba. Contributions to Canadian Palaeontology 1, 151-196.

Williston, S.W. 1896. The Kansas Niobrara Cretaceous. The University Geological Service of Kansas 2, 235-246.

Withers,T.H. 1911. Some Cirripedes from the Chalk of Salisbury. Geological Magazine (5)8, 21-31.

Withers, T.H. 1913. Cirripedes from the Cenomanian Chalk Marl of Cambridge. Proceedings of the Zoological Society of London 95, 937948.

Withers, T.H. 1920. The cirripede genus Stramentum (Loricula); its history and structure.Annals and Magazine of Natural History (9)5, 65-84, pls 3, 4.

Withers, T.H. 1928. British Museum (Natural History). Catalogue of the Fossil Cirripedia in the Department of Geology. Vol. 1. Triassic and Jurassic. 154 pp., 12 pls. London, Dulau \& Co. 
Withers, T.H. 1935. British Museum (Natural History). Catalogue of the Fossil Cirripedia in the Department of Geology, Vol. 2. Cretaceous. 534 pp., 50 pls. Adlard \& Sons Ltd., London.

Withers, T.H. 1945. New Cretaceous cirripedes and crab. Annals and Magazine of Natural History (12)11, 552-561.

Wittler, F. 1996. Erster Nachweis des lepadomorphen Cirripedier Stramentum (Stramentum) pulchellum (G.B. Sowerby, 1843) aus dem Mittleren Turon des Dortmunder Stadtgebietes nebst Bemerkungen zur Palökologie und Überlieferungsproblematik der Stramentiden. Arbeitskreis Palaöntologie Hannover 24, 85-118.

Wood, C.J. 1988. The stratigraphy of the chalk of Norwich. Bulletin of the Geological Society of Norfolk 38, 3-120.

Woodward, H. 1908a. A large cirripede of the genus Loricula from the chalk of Kent. Geological Magazine (4)5, 491-499.

Yamaguchi, T., Newman, W.A. and Hashimoto, J. 2004. A cold seep barnacle (Cirripedia, Neolepadinae) and the age of the vent/seep fauna. Journal of the Marine Biological Association of the United Kingdom 84, 903-908.

Young, P.S. 2001. Redescription of Scalpellopsis striatociliata Broch, 1922, with a discussion on its phylogenetic position and the peduncular plate pattern in scalpellids. Journal of Crustacean Biology 21, 456-468.

Zittel, K.A. von. 1885. Bemerkungen über einige fossile Lepaditen aus dem lithographischen Schiefer und der oberen Kreide. Sitzungsberichte der Bayerischen Akademie der Wissenschaften 14 (for 1884), 577-589.

\section{FIGURE CAPTIONS}

Figure 1. A, B, Praelepas jaworskii Chernyshev, 1930. 'Middle Carboniferous' (probably Namurian), Kuznetsyski Basin, right shore of River Mungat, near Krapivinski Mine, Ukraine. A, NHMUK In. 31349; B, In. 31333. C, Eolepas aalensis (Richardson, 1908), Oberer Hauptrogenstein (Bathonian, Parkinsonia parkinsoni Zone), Auenstein, Canton Aargau, Switzerland, after Schweigert (2014), PIMUZ 1812a. D, Eolepas bathonica Withers, 1928, 
Bathonian, Lion-sur-Mer, Calvados, Normandy, France. NHMUK In. 61779. E, Ibla cumingi Darwin (after Darwin 1851b). Scale bars A, C-E, 5 mm; B, 2 mm.

Figure 2. Homologies of scalpellomorphs. Carina and carinal column of peduncular scales green; carinolatus column pink; upper latus column yellow; scultal/rostroscutal column brown; rostral column mauve. A, Idioibla pygmaea (Broch,1922). B, Praelepas jaworskii Chernyshev,1930; C, Eolepas bathonica Withers, 1928; D, Archaeolepas redtenbacheri (Oppel, 1862). E, Stramentum pulchellum (G.B. Sowerby Jr, 1843); F, Arcoscalpellum michelottianum (Seguenza, 1876). R, rostrum; S, scutum; T, tergum; C, carina; UL, upper latus; $\mathrm{RL}$, rostrolatus; $\mathrm{ML}$, inframedian latus; $\mathrm{CL}$, carinolatus.

Figure 3. Archaeolepas redtenbacheri (Oppel, 1862). A, B, original of von Zittel (1885, text-fig.1b).Tithonian, Lithographic Stone, Solnhofen, Bavaria, Germany. C, D, original of Oppel (1862, pl. 37, fig. 6). Tithonian, Lithographic Stone of Kelheim, Bavaria, Germany. Both specimens in the Bayerische Staatssammlung für Paläontologie und historische Geologie, München. Photographs provided by Günter Schweigert, Stuttgart. Scale bar $10 \mathrm{~mm}$.

Figure 4. A, D, E. Loriolepas suprajurensis (de Loriol, in de Loriol and Pellat, 1867); A, Complete capitulum, Tithonian, Tour de Croi, near Boulogne-surMer, northwest France (private collection, Paris, fossilesboulonnais@free.fr) x 4. D, Tergum, exterior view (original of Withers 1928, pl. 5, fig. 10; NHMUK In. 27430). E, scutum in external view (original of Withers 1928, pl. 5, figs. 8, 9; NHMUK In. 24729). D, E are from the Tithonian, near Boulogne-sur-Mer, northwest France. B, C, F, G. Loriolepas decora (Harbort, 1905). B, D, lateral views of individuals. F, external view of scutum (original of Withers 1935, pl. 1, fig. 5). G, tergum, external view (original of Withers 1935, pl. 1, fig. 6). Lower Valanginian, Platylenticeras heteropleurum Zone, Musingen, near Bückeberg, Schaumberger Lippe, northwest Germany. Geological Institute of Göttingen University. Scale bars $5 \mathrm{~mm}$.

Figure 5. Diagram to illustrate the thoracican phylogeny proposed by Newman (1979), and modified from his figure 5, demonstrating how ontogeny reflects 
phylogeny, and how successive taxa appear in the correct stratigraphical order. At the bottom are the successive ontogenetic stages of the living Pollicipes polymerus (after Broch 1922), showing the progressive acquisition of plates after metamorphosis. Praelepas is interpreted as representing the stage with only scuta, terga and carina; Eolepas acquired a rostrum; Neolepas has an upper latus, and finally, Calantica has a full compliment of plates. The record of Neolepas from the Lower Jurassic is from Buckeridge and Grant-Mackie (1985). Scutum brown, tergum yellow, carina mauve, rostrum blue, upper latus dark green, inframedian latus pale green. Compare with the cladogram of basal thoracican relationships shown in Fig. 6; the main differences are that 1) Neolepas is now thought to be a derived taxon which has secondarily lost all laterals except the upper latus (following PérezLosada et al. 2008; Gale 2014b), rather than a basal form and 2) there is fundamental division between phosphatic forms including Praelepas and Eolepas, which are basal thoracicans and close to iblids, and the derived calcareous thoracicans.

Figure 6. Cladogram of basal thoracican relationships, based on a consensus tree constructed using unconstrained heuristic analysis (stepwise additions option random, branch swapping optio TBR), optimised to deltran, analysed with PAUP. Based on 12 shell plate characters (see Supplementary material), bootstrap values shown. The iblids Ibla and Idioibla are basal to the tree, and evolution involved 1) progressive acquisition of plates, carina, rostrum, peduncular plates, upper latus, carinolatus, and finally, inframedian latus and rostrolatus, and 2) a major transition in shell plate mineralogy from phosphatic to calcitic. The calcareous thoracicans are identified as the clade Thoracicalcarea nov., of unidentified taxonomic status. Compare with Fig. 5.

Figure 7. Cladogram of stramentid relationships, using Archaeolepas and Eolepas as outgroups. This is a consensus tree constructed using unconstrained heuristic analysis stepwise additions option random, branch swapping optio TBR, optimised to deltran, analysed with PAUP. Based on 25 characters (see Supplementary material), bootstrap values shown. Although strongly supported as a monophyletic group, resolution within the 
Stramentidae is poor, although the Loriculinae are moderately well supported, and Parastramentum gen. nov. and Stramentum elegans Hattin, 1977 are closely related, as also deduced from stratigraphical occurrences. High homoplasy levels, including numerous reversals and parallels, probably account for the poor resolution. Archaeolepas redtenbacheri, Metaloriculina stramentioides, Loriculina ifrimae, Leweslepas hauschkei, Angulotergum moorei, Parastramentum peakei, Stramentum elegans, Stramentum pulchellum. Loric. $=$ Loriculinae.

Figure 8. Terminology of the stramentid skeleton (after Hattin 1977, text-fig. 2). Note that the term rostral slip is here replaced with rostral articulation surface. The peduncular plate columns are 1) rostral, 2) scutal, 3) upper latus, 4) carinolatus and 5) carinal.

Fig. 9. Drawings and photographs of Loriculinae nov. A, Loriculina ifrimae sp. nov., based on the holotype (see Figure 10B). Lower Coniacian, Yellow Limestone Member of Carranza, northern Coahuila, Mexico, attached to ammonite Peroniceras, CPC-159. B, Loriculina laevissima von Zittel, 1885, drawing of holotype (original of Loricula laevissima von Zittel, 1885, fig. 4). Oberer Kreidemergel, Dülmen, Westphalia, Germany, lower Campanian. Bayerische Staatsssammlung für Paläontologie und historische Geologie, München. C, F, Loriculina noetlingi Dames, 1885, holotype (original of Dames, 1885, fig. 2). Fish Bed, Sahel Alma, Lebanon, upper Santonian. Museum für Naturkunde, Berlin. D, Blastolepas orlovi Drushhvits and Zevina, 1969. Aptian, Caucasus. E, Metaloriculina stramentoides gen. et sp. nov., drawing of holotype shown in Fig. 12C. Lower Coniacian, Yellow Limestone Member of Carranza, northern Coahuila, Mexico, all attached to ammonite Peroniceras, CPC-159. Scale bars $5 \mathrm{~mm}$.

Figure 10. A-D, Loriculina ifrimae sp. nov. B, holotype (original of Ifrim et al. 2011, fig. 5/6, as Stramentum pulchellum). A, C, D, paratypes.

Lower Coniacian, Yellow Limestone Member of Carranza, northern Coahuila, Mexico, all attached to ammonite Peroniceras tridorsatum. CPC-159 (see Ifrim et al. 2011, fig. 4). See also Figure 9A. Note particularly the transversely 
arranged, rectangular tergum and the abutting peduncular plates of the carinolatus and upper latus columns. Scale bars $2 \mathrm{~mm}$.

Fig. 11. Peduncular construction in Loriculinae nov., based on isolated plates of Metaloriculina norvicensis gen. et sp. nov. from the Belemnitella mucronata Zone, Newfound Farm Pit, Cringleford, Norwich, Norfolk, UK (Fig. 13), and articulated specimens of $M$. stramentoides gen. et sp. nov. from Mexico, shown in Fig. 12. The lower drawing shows a cross section of the peduncle.

Fig 12. A-D, Metaloriculina stramentoides gen. et sp. nov. C, holotype (original of Ifrim et al. 2011, fig. 5/4, as Stramentum pulchellum). A, B, D, paratypes. Lower Coniacian, Yellow Limestone Member of Carranza, northern Coahuila, Mexico, attached to ammonite Peroniceras, CPC-159 (see Ifrim et al. 2011, fig. 4). Note the rhombic scutum, with a central to slightly subcentral umbo, and the transversely arranged tergum and carinolatus, as in Loriculina (see also Fig. 9A, E). Scale bars $2 \mathrm{~mm}$.

Figure 13. A-L, Metaloriculina norvicensis gen. et sp. nov. A, peduncular plate from upper latus column. NHMUK IC 1223. B, E, carinolatera, external view. B, NHM IC 1224; E, 1226 (holotype). C, D, peduncular plate from scutal column in lateral and apical views NHMUK IC 1225. F, G, peduncular plate from rostral column, external and internal views. NHMUK IC 1227. H, peduncular plate of lower rostral column. NHMUK IC 1228. I, K, peduncular plates from carinolatus column. NHMUK IC 1229,1231. J, L, peduncular plates from carinal column. NHMUK IC 1230, 1232. All from the lower Belemnitella mucronata Zone, Newfound Farm Pit, Cringleford, Norwich, Norfolk, UK. Scale bars $0.5 \mathrm{~mm}$.

Figure 14. A, B, Leweslepas hattini gen. et sp. nov., Bed 48 of Kennedy \& Gale (in press), OUM K.38133. C, D, Leweslepas hauschkei gen. et sp. nov., Bed 62 of Kennedy \& Gale (in press). A,C, Drawings of capitula of holotypes (see Fig. 15A, C). B, D, reconstructions. Lower Cenomanian, Chalk Marl, Mantelliceras dixoni Zone, Southerham Grey Pit, Lewes, Sussex, UK. Scale bar $2 \mathrm{~mm}$. 
Figure 15. A, Leweslepas hattini gen. et sp. nov. Holotype, complete individual, attached to flank of ammonite Acompsoceras sp. Lower Cenomanian, Chalk Marl, Mantelliceras dixoni Zone, Bed 48 of Kennedy \& Gale (in press). Southerham Grey Pit, Lewes, Sussex, UK. OUM K.38133. B, C, D, Leweslepas hauschkei gen. et sp. nov., group of four individuals (D) attached to flank of Acompsoceras sp. The best-preserved specimen (enlarged in C) is holotype (OUM K.64093), the other three are paratypes (OUM K.64094-6). B, interior of the scutum of OUM K.64094. Lower Cenomanian, Chalk Marl, Mantelliceras dixoni Zone, Bed 62 of Kennedy \& Gale (in press). E, Leweslepas acuminata (Darwin, 1851a), original figure after Darwin (1851a: 56, pl. 3, fig. 6, Pollicipes acuminatus. "Mus. Flower, believed to have come from the Lower Chalk of Stoke Ferry, Norfolk)", probably Cenomanian. Specimen presumed lost. F, Leweslepas wrightorum gen. et sp. nov., exterior of scutum, lower Cenomanian (Schloenbachia varians Zone), Lower Chalk, Chalk Marl, Compton Bay, Isle of Wight, UK. NHMUK In. 62539. Scale bars $5 \mathrm{~mm}$ (A, D), 1 mm (B), 2 mm (C, F).

Figure 16. A-C, Stramentum pulchellum (G.B. Sowerby Jr, 1843).All specimens from the lower Turonian Chalk of Cuxton, near Rochester, Kent. $\mathrm{A}, \mathrm{B}$, large individuals attached to ammonite Lewesiceras sp., syntypes of Loricula darwini H. Woodward, 1908 (p. 493, fig. 1; also figured by Withers 1935, pl. 41, figs. 2, 3), NHMUK In. 9130. C, Holotype (original of Loricula pulchella G.B. Sowerby jun.1843, figs. 1, 2; also figured by Darwin 1851, pl. 5, fig. 1; Withers 1920, pl. 3, fig. 3; Withers 1935, pl. 41, fig. 4), NHMUK In. 59150. This specimen retains its original convexity. D, Stramentum praecursor sp. nov. Holotype, attached to ammonite Acanthoceras rhotomagense, SM B.8935. Although there are no locality details, both the preservation and identity of the ammonite indicate provenance from the Turrilites costatus Subzone of southern England, probably Kent. Scale bars 5 $\mathrm{mm}$.

Figure 17. Ontogeny of Stramentum pulchellum (G.B. Sowerby Jr, 1843), and S. inconstans Collins, 1986. A-D represent a growth series of individuals, from 
various localities. A, B, after Hauschke (1994); A is taken from his pl. 4, fig. 3, B from pl. 3, fig. 3. Upper Cenomanian, Westphalia, Germany. C, holotype of S. pulchellum, NHMUK In. 59150. D, largest known individual, holotype of Loricula darwini $\mathrm{H}$. Woodward, 1908, NHMUK In.19130. C, D, both from lower Turonian of Cuxton, near Rochester, Kent, UK. E, cross plot of total height vs number of peduncular plate columns. Asterisks represent S. pulchellum, crosses $S$. inconstans. A, B, C in C represent the three successive growth stages found in stramentid peduncular plates of the upper latus column; early divergent growth zone $A$; constant width mid growth zone $B$, and late growth zone C. Scale bars $1 \mathrm{~mm}(A), 5 \mathrm{~mm}(B, C)$ and $10 \mathrm{~mm}(D)$.

Figure 18. A, C-G, Stramentum inconstans Collins, 1986. A, enlargement of capitulum of large individual, NHMUK In. 62059, original of Collins (1986, fig. 2). C, D, large individual, with well-preserved peduncle; D, enlargement of peduncular plates on rostral side to show processes on rostral column of plates which alternate with those of the scutal column. NHMUK In. 62161. E, small individual, shown in E; NHMUK In. 62055. E, individuals of different sizes and stages of growth. Large individual on the left is NHMUK In. 62057. G, holotype (left), NHMUK In. 62053. Lower Turonian, Mammites nodosoides Zone of the Eze-Aku Formation of Lokpanta, eastern Nigeria. B, enlarged capitulum of S. pulchellum, type of Loricula darwini H. Woodward, 1908, Turonian, Cuxton, Kent, UK. NHMUK In. 19130. Scale bars 5 mm (A-C, F, G) and $2 \mathrm{~mm}(\mathrm{D}, \mathrm{E})$.

Figure 19. A-D, Stramentum haworthi (Williston, 1896). A, individual showing interior of peduncular plates, only the capitular plates remain of the upper side. NHMUK In. 22640. B, two small individuals in similar preservation, probably in life orientation. NHMUK In. 21940. C, exceptionally well-preserved individual, all plates intact except base of peduncle. Original of Withers (1920, pl. 4, fig. 3; 1935, pl. 42, fig. 5). NHMUK In.15945. D, large individual in common preservational mode, with some disarticulation. Original of Withers (1920, pl. 4, fig. 2; 1935, pl. 42, fig. 4). NHMUK In. 15945. All attached to baculitid ammonites, shown in Fig. 20. The individual shown in $C$ is at the top of Fig. 
20C. Niobrara Chalk, horizon with Uintacrinus socialis (upper Santonian) of Elkader, Kansas. Scale bar $5 \mathrm{~mm}$.

Figure 20. Slabs of pinkish-buff chalk each containing part of a large poorly preserved baculitid ammonite, on the flanks of which are attached specimens of Stramentum haworthi. A, NHMUK In. 18989. B, NHMUK In. 18990. C, NHMUK In. 15945, individuals figured in Fig. 19C, D. D, NHMUK In. 22640. Note the concentration of individuals towards the mid-flank; no individuals have attached to the dorsal or ventral margins of the ammonites. Niobrara Chalk, horizon with Uintacrinus socialis (upper Santonian) of Elkader, Kansas. Scale bar $10 \mathrm{~mm}$.

Figure 21. Angulatergum moorei (Hattin, 1977). A, group of individuals, paratypes, original of Hattin (1977, pl. 3, fig. 17), KU 111594. B, incomplete large individual, paratype, original of Hattin (1977, pl. 4, fig. 23), KU 111659. C, paratype, original of Hattin (1977, pl. 3, fig. 15), KU 111658. D, scutum and rostrum, paratype, original of Hattin (1977, pl. 4, fig. 22), KU 111612. Holotype, original of Hattin (1977, pl. 3, fig. 18), KU 111588. All from Lincoln Limestone Member of Greenhorn Formation, Russell County, Kansas. Middle Cenomanian, Plesiacanthoceras wyomingense Zone. Scale bars $5 \mathrm{~mm}$ (A) and $2 \mathrm{~mm}$ (B-E).

Figure 22. Stramentum elegans Hattin, 1977. C, G, paratype, original of Hattin (1977, pl. 1, fig. 5). A, juvenile, Hodgeman County, KU 111522. B, paratype, original of Hattin (1977, pl. 1, fig 6), KU 8073-A, Osborne County. C, holotype, original of Hattin (1977, pl. 1, fig. 4), KU 111520. Ellis County. D, group of specimens attached to Inoceramus shell; external growth lines run from the top to the bottom. E, interior of tergum, original of Hattin (1977, pl. 2, fig. 6), Ellis County, KU 111576. F, interior of scutum, original of Hattin (1977, pl. 2, fig. 11), Hodgeman County, KU 111661. H, slightly disarticulated individual showing rostrum and paired scuta. I, individual showing interior of tergum, original of Hattin (1977, pl. 2, fig. 7), Ellis County, KU111569. J, large scutum, unregistered. Fairport Chalk Member of Carlile Shale Formation, middle 
Turonian, Collignoniceras woollgari Zone, Kansas. Scale bars $2 \mathrm{~mm}(A, D, H, I)$, $5 \mathrm{~mm}(\mathrm{~B}, \mathrm{C}, \mathrm{E}-\mathrm{G})$.

Fig. 23A-D, Zeugmatolepas cretae (Steenstrup,1839). A, B, scutum, external (A) and internal views, upper Campanian, Belemnitella mucronata Zone, Weybourne Chalk, Keswick, Norwich, UK. NHMUK IC 1233. C, D, scutum, holotype of Stramentum biplicatum Jagt \& Collins,1989, Zeven Wegen Chalk Member, upper Campanian, CPL Quarry, Haccourt, Belgium. Original of Jagt \& Collins (1989, fig. 4J,K), NHMUK In. 63637. F, Stramentidae?; scutum, external aspect. NHMUK IC 1235, Upper Campanian, Belemnitella mucronata Zone, Newfound Farm Pit, Cringleford, Norwich, Norfolk, UK. E, M, Parastramentum peakei gen. et sp. nov. E, large tergum in external aspect. NHMUK IC 1234. M, holotype scutum, in external view. NHMUK IC 1238. Upper Campanian, Belemnitella mucronata Zone, Newfound Farm Pit, Cringleford, Norwich, Norfolk, UK. G, H. Parastramentum brydonei gen. et sp. nov. Holotype tergum, in external $(G)$ and internal $(H)$ views. Upper Turonian, Holaster planus Zone, Froxfield, Hampshire, UK. Pit no. 125 of Brydone (1912), SM 76166. I-K, Metaloricula norvicensis gen. et sp. nov., scuta, external and internal views (I, J) of paratype scutum NHMUK IC 1236; K, paratype scutum, IC 1237. Belemnitella mucronata Zone, Newfound Farm Pit, Cringleford, Norwich, Norfolk, UK. N-P, Parastramentum expansum (Withers, 1911). N, O, scuta, O is holotype and original of Withers's (1911, fig. 8a, b) Loricula expansa. NHMUK In. 13812. N is NHMUK In. 27275. P, tergum, figured as Loriculina laevissima (von Zittel, 1885) by Withers (1935, pl. 40, fig. 13). NHMUK In. 30527. Actinocamax quadratus Zone (lower Campanian), East Harnham, Salisbury, Wiltshire, UK. L, Parastramentum sp., tergum, figured as Loriculina laevissima (von Zittel) by Withers (1935, pl. 40, fig. 12). Offaster pilula Zone (lower Campanian) coast of Sussex, UK. NHMUK In. 32491, Scale bars $1 \mathrm{~mm}(\mathrm{~A}-\mathrm{E}, \mathrm{G}, \mathrm{H}, \mathrm{L}-\mathrm{P})$ and $0.5 \mathrm{~mm}(\mathrm{~F}, \mathrm{I}-\mathrm{K})$.

Figure 24. A-N, Parastramentum peakei gen. et sp. nov. A-H, scuta, in external $(A, B, E, G, H)$ and internal $(C, D)$ aspects to show morphological variation. $F$, shows the distinctive elongated primordial valve. A, holotype, NHMUK IC 1238; B, IC 1239; C, IC 1240; D, 1241; E,F, IC 1242; G, IC 1243; 
$\mathrm{H}, 1244$. I, J, carinolatera, in external and internal aspects, NHM IC 1245, IC 1246. K, L, tergum in external and internal views, NHMUK IC1247. M, N, upper latera, in external and internal aspects, NHMUK IC 1248, IC 1249. Belemnitella mucronata Zone, Newfound Farm Pit, Cringleford, Norwich, Norfolk, UK. O, P, Stramentum pulchellum (G.B. Sowerby Jr, 1843), tergum in external $(\mathrm{O})$ and internal $(\mathrm{P})$ aspects. Upper Turonian, Holaster planus Zone, Froxfield, Hampshire, UK. Pit no.125 of Brydone (1912), SM 76163. Compare with tergum of Parastramentum peakei gen. et sp. nov. (K, L). Scale bars 1 $\mathrm{mm}$.

Figure 25. A-D, J, K, N-P. Parastramentum peakei gen. et sp. nov., peduncular plates. Compare with reconstruction shown in Fig. 27. A, D, plates from upper latus column, NHMUK IC 1250,1253. B, plate from carinolatus column, NHMUK IC 1251. C, plate from scutal column, NHMUK IC 1252. J, K, $\mathrm{N}, \mathrm{O}$, plates from either rostral or carinal columns, NHMUK IC 1254-7. P, plate from unknown position, NHMUK IC 1258. Belemnitella mucronata Zone, Newfound Farm Pit, Cringleford, Norwich, Norfolk, UK (Wood 1988). E-I, L, M, Q, R. Stramentum cf. inconstans Collins, 1986. E, external aspect of broken scutum. NHMUK IC 1259. F, Q, R, terga, F, NHMUK IC 1260; Q,R, IC 1266. G, carinolatus, NHMUK IC 1261. I, upper latus, NHMUK IC 1263. H, L, M, peduncular plates, L from upper latus column, NHMUK IC 1262, 1264, 1265. E,F,H,I,L,M, Lower Turonian, Mammites nodosoides Zone, region of Goulemima, Morocco; G, escarpment $3 \mathrm{~km}$ northeast of the village of Asfla, $30 \mathrm{~km}$ north of Goulmima, Morocco, equivalent horizon to 20 and $23 \mathrm{~m}$ in Kennedy et al. (2008, fig. 2). Scale bars $1 \mathrm{~mm}$ (A-C, E-I, L, M, Q, R) and 0.5 $\mathrm{mm}(\mathrm{D}, \mathrm{K}, \mathrm{N}-\mathrm{P})$.

Figure 26. A,Stramentum pulchellum (G.B. Sowerby Jr, 1843). Turonian, Black Head Bay, Antrim, Northern Ireland. Holotype of Loricula macadami Thomson, in MacAdam,1858, p. 322, Belfast Museum, no. 1920-1. B, C, Stramentum praecursor sp. nov. Paratype, attached to ammonite Acanthoceras (B). Middle Cenomanian, Lower Chalk, Turrilites costatus Subzone, Glynde, near Lewes, Sussex, UK. BM 00686. Scale bars $10 \mathrm{~mm}$ (A, $\mathrm{B})$ and $5 \mathrm{~mm}(\mathrm{C})$. 
Figure 27. Peduncular construction in Stramentinae, illustrated by Parastramentum peakei gen. et sp.nov., based partly on material illustrated photographically in Fig. 25A-D, J, K, N-P. Lower image shows reconstructed cross-section. Compare with Fig. 11.

Figure 28. A, B, Parastramentum peakei gen et sp. nov. Cast taken from the interior of peduncle of individual overgrown by oyster. Probable locality "Chalk of Norwich, upper Campanian", T.G. Bayfield Coll., NHMUK 42012. Note asymmetry and angulation between peduncular plates of carinolatus $(\mathrm{Cl})$ and scutal (s) columns. C,D, Stramentum alekseevi sp. nov., holotype scutum, external and internal views (original of Alekseev 2009, fig. 4/22a, b). Locality 10 of Alekseev (2009), upper Turonian, Mangyshlak, Kazakhstan, Moscow State University collections, no. 270/22. E, Angulatergum texanum (Withers, 1945), original of Withers (1945, p. 557, fig. 7). Walnut Formation (middle Albian) of Nolan Creek, east of Nolanville, Bell Co., Texas, attached to an ammonite, Oxytropidoceras. University of Texas Collection no. 2500. F, G, Parastramentum albertaensis gen. et sp. nov, photograph and interpretative drawing of holotype, attached to flank of ammonite, Placenticeras, Aurora Ammolite Mine, Lethbridge, Alberta, Canada. Photograph courtesy of Mr Rusty Pimm. Specimen in Royal Tyrrell Museum, Drumheller, Alberta, Canada, TMP 2009.056.0004. Scale bars 2 mm (A-E) and $10 \mathrm{~mm}(\mathrm{~F}, \mathrm{G})$. Abbreviations; s, scutal; ul, upper latus; $\mathrm{cl}$, carinolatus; $\mathrm{C}$, carinal columns.

Figure 29. Hypothesised evolution in the Leweslepas gen. nov.-StramentumParastramentum gen. nov. lineage, from the lower Cenomanian to the Campanian. Note the migration of the scutal umbo from an apical to a central position; the marked change in capitular angle between S. praecursor sp. nov. and S. pulchellum; changes in the shape and orientation of the tergum and carinolatus. The lowest three species probably represent phyletic evolution; the upper three continue the morphological trend. 
1) skeleton phosphatic (0); skeleton calcareous (1)

2) scutum flat, triangular (0); pentagonal (1); scutum concavo-convex, triangular

(2)

3) tergum triangular(0); tergum rhomboidal (1)

4) contact between scutum and tergum subparallel with long axis (0); obliuqe, tergum sits above scutum (1)

5) carina absent (0); tall concavo-convex, triangular carina present (1)

6) rostrum absent (0); triangular concavo-convex rostrum present (1)

7) upper latus absent (0); present (1)

8) carinolatus absent (0); present (1)

9) rostrolatus absent (0); present (1)

10) inframedian latus absent (0); present (1)

11) peduncular plates absent (0); 8-10 columns present (1)

12) peduncular plates imbricate strongly (0); no imbrication (1)

Ibla

Idioibla

Praelepas

Eolepas

Archaeolepas

Stramentum

Arcoscalpellum

Virgiscalpellum 
Ibla

2

3

4

5

Idioibla

0

0

Praelepas

0

1

Eoepas

Archaeolepas

Stramentum

Arco

Vrigi

0

2

2

2

2

2

0

0

1

1

1

1

1

1

0

0

1

1

1

1

1

1 


$\begin{array}{rrrrrr}6 & 7 & 8 & 9 & 10 & 11 \\ 0 & 0 & 0 & 0 & 0 & 0 \\ 0 & 0 & 0 & 0 & 0 & 0 \\ 0 & 0 & 0 & 0 & 0 & 0 \\ 1 & 0 & 0 & 0 & 0 & 0 \\ 1 & 0 & 0 & 0 & 0 & 1 \\ 1 & 1 & 1 & 1 & 0 & 1 \\ 1 & 1 & 1 & 1 & 1 & 1 \\ 1 & 1 & 1 & 1 & 1- & \end{array}$




$$
\begin{aligned}
& 0 \\
& 0 \\
& 1 \\
& 0
\end{aligned}
$$


30.6 .2015

Dear Paul and Greg

I have now completed revision of this paper and therefore resubmit. I have dealt in detail with all the comments of the referees. The substantial comments by Greg about the nature of the heuristic analysis have been dealt with; I have checked with a cladistic expert who assures me that the characters are unconstrained (there are some binary characters in both matrices) and gone over the procedure in more detail, amending text and captions.

As all other comments are minor I do not see any need to justify the changes, but will be happy to do so if you see fit.

All best wishes, Andy 


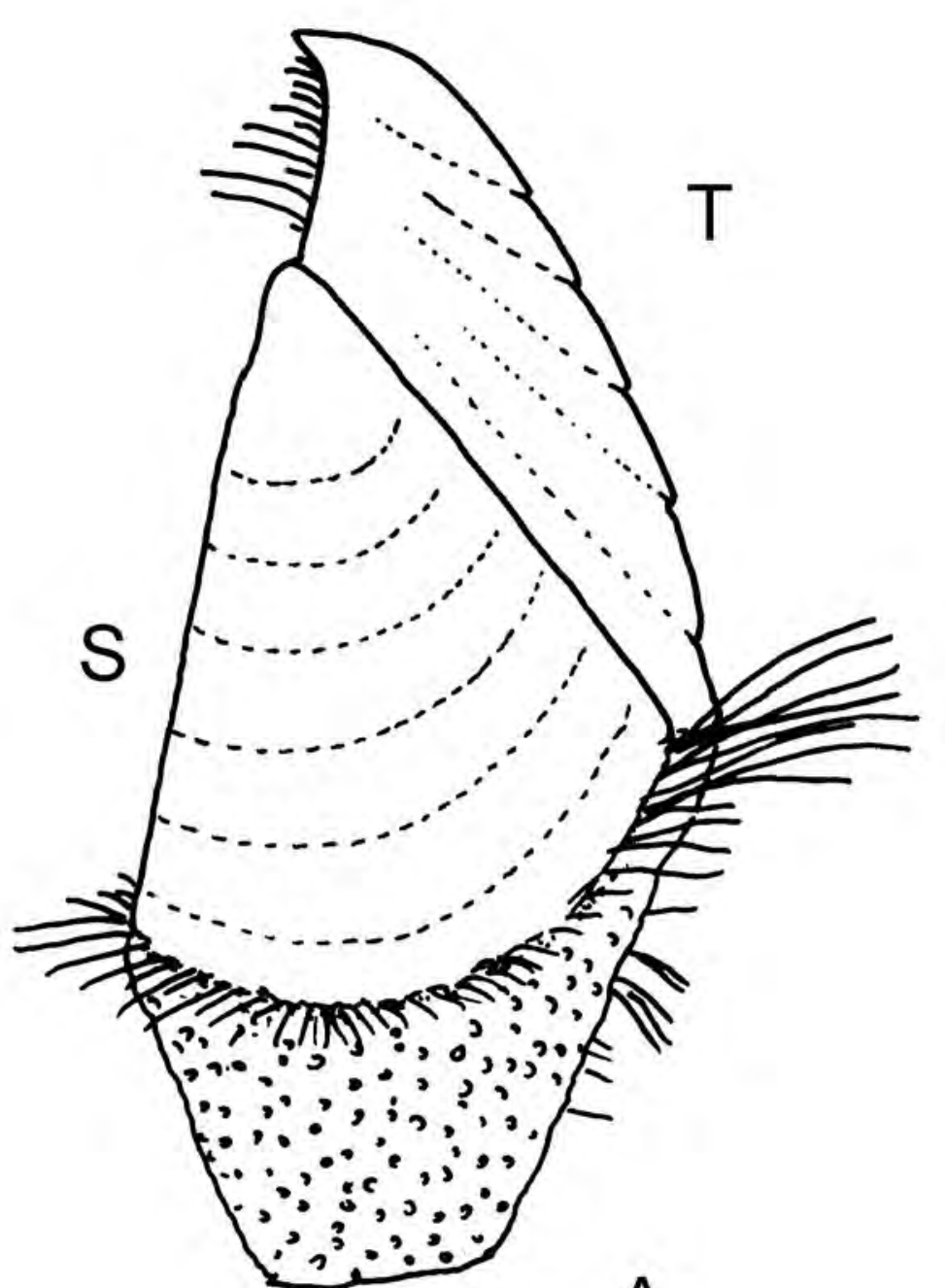

A

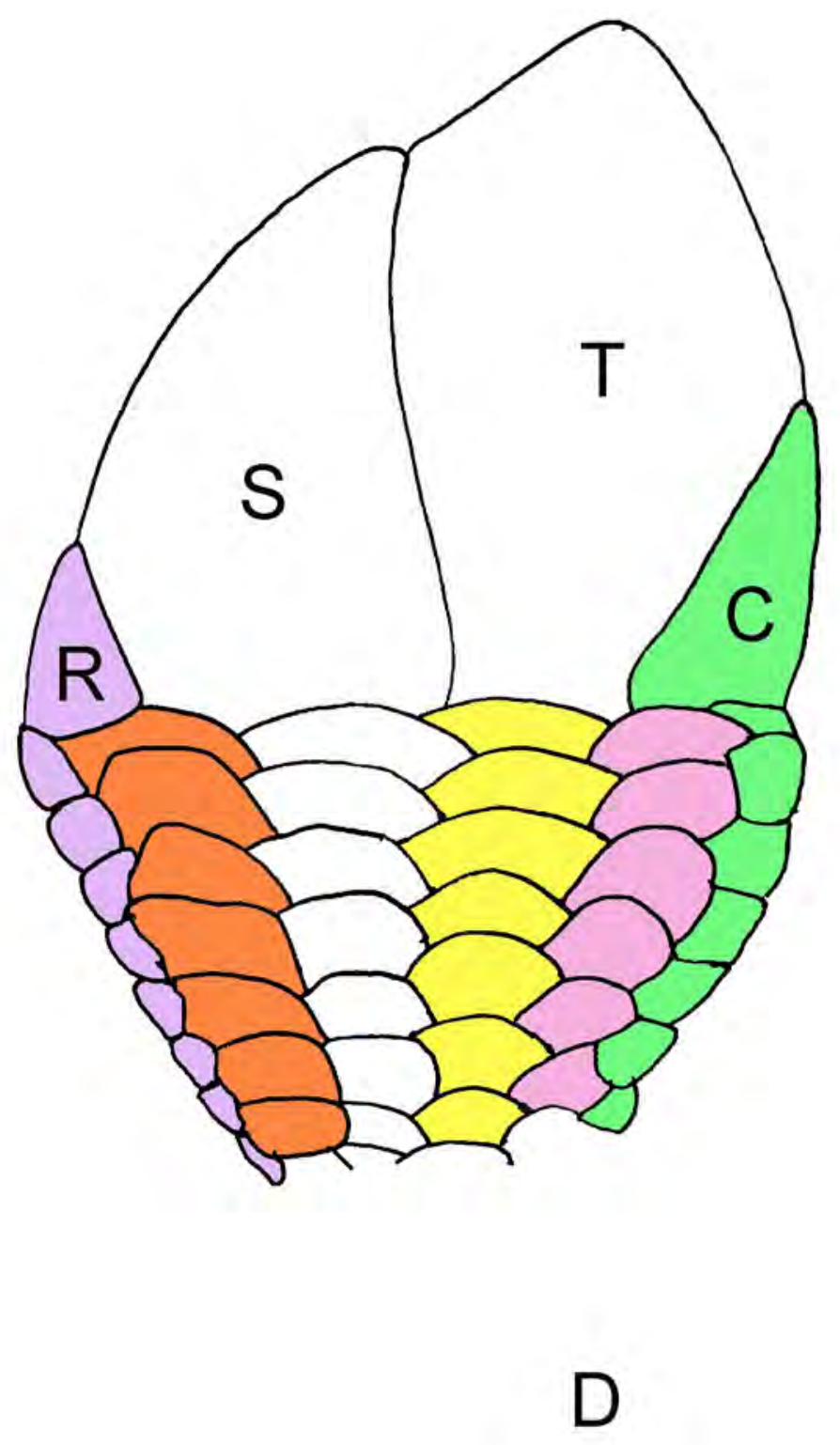

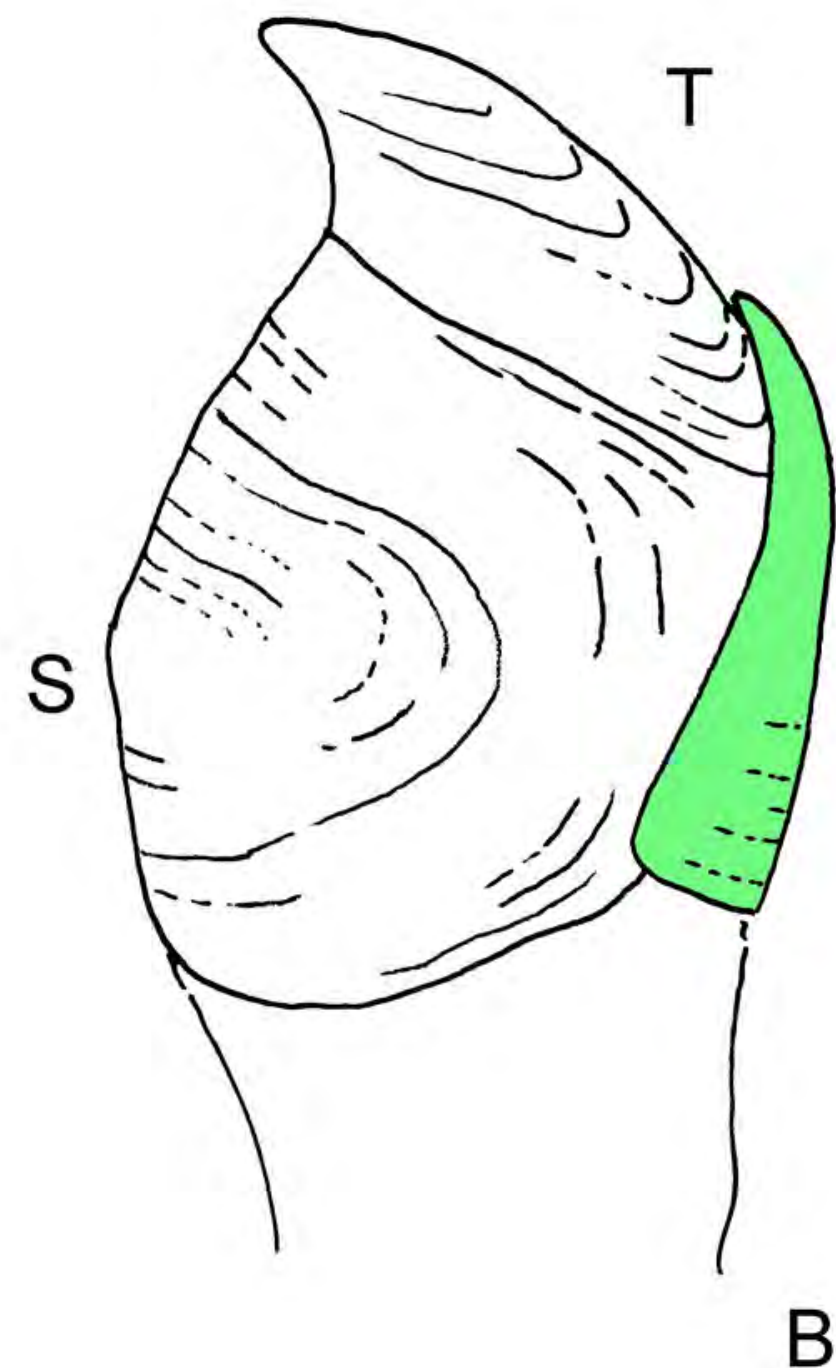
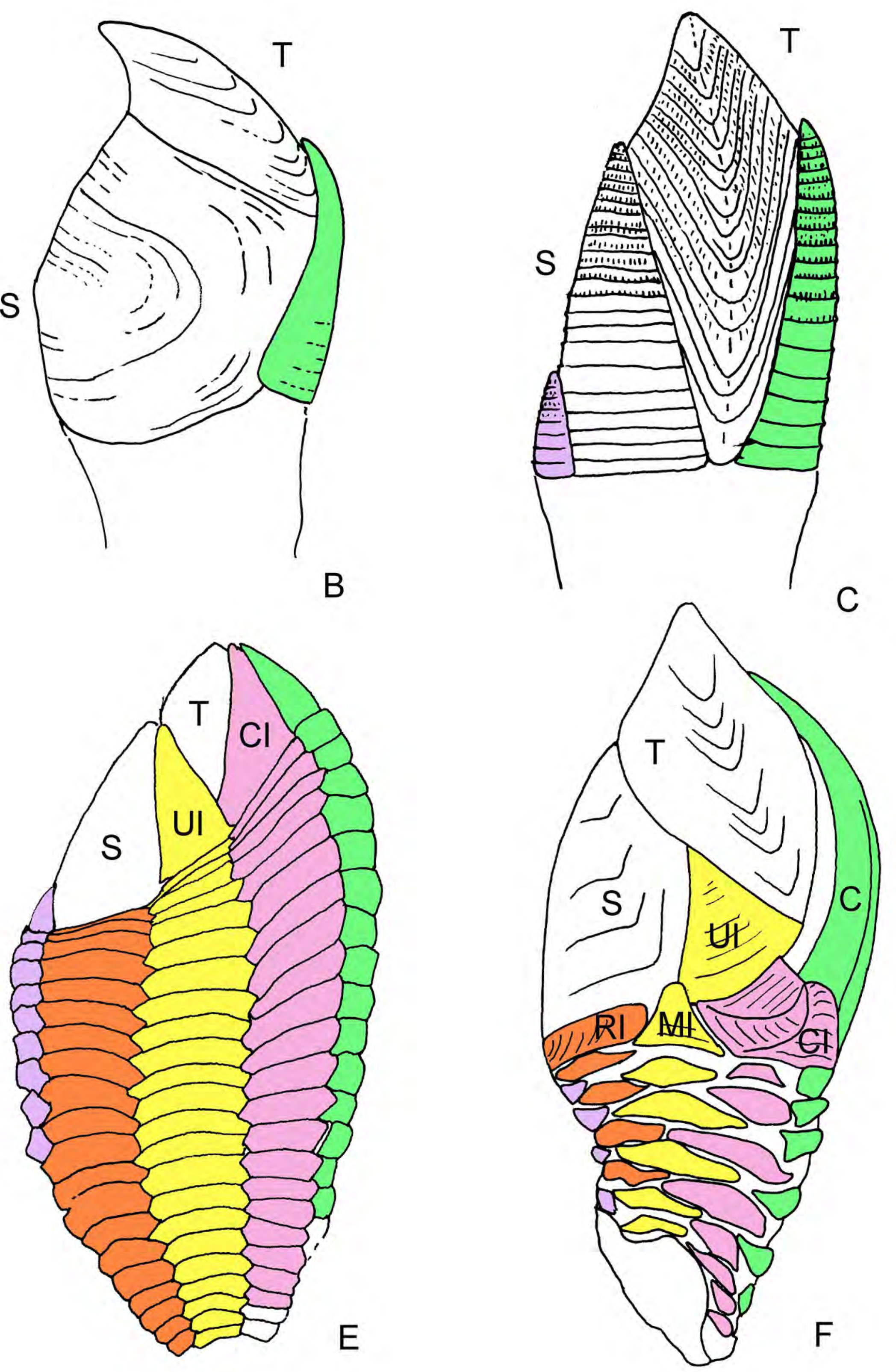

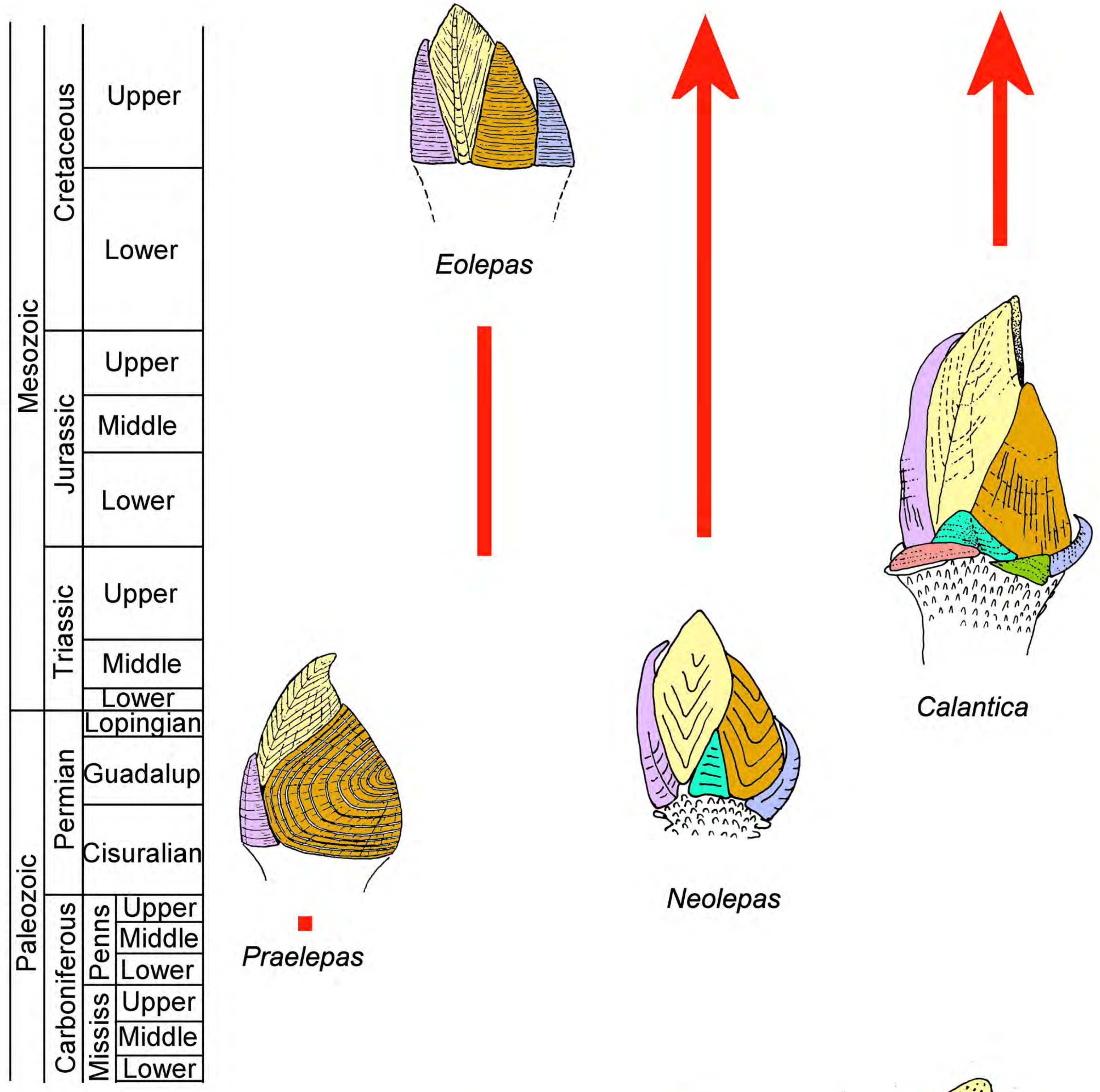

Calantica

\section{Neolepas}
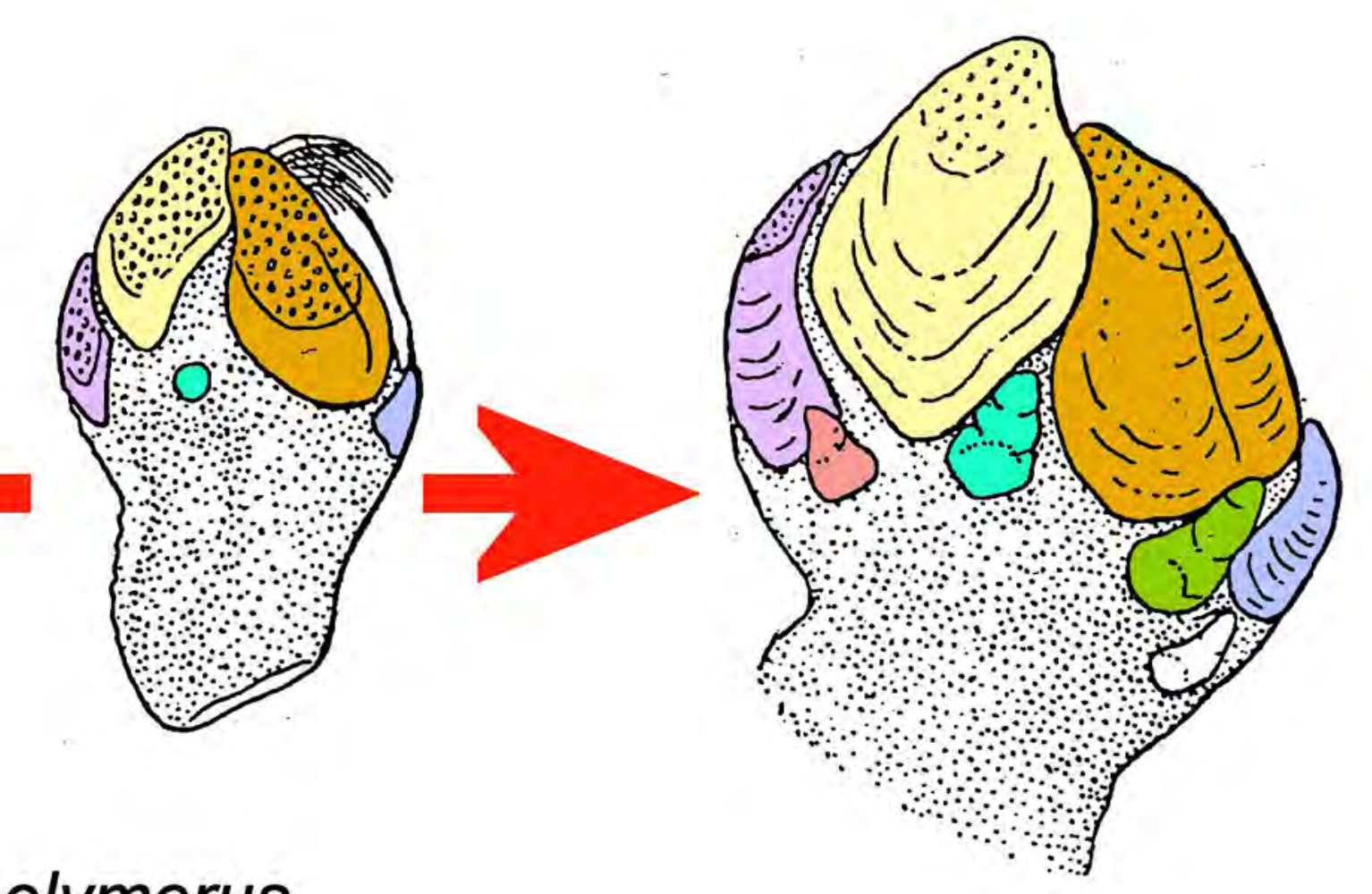


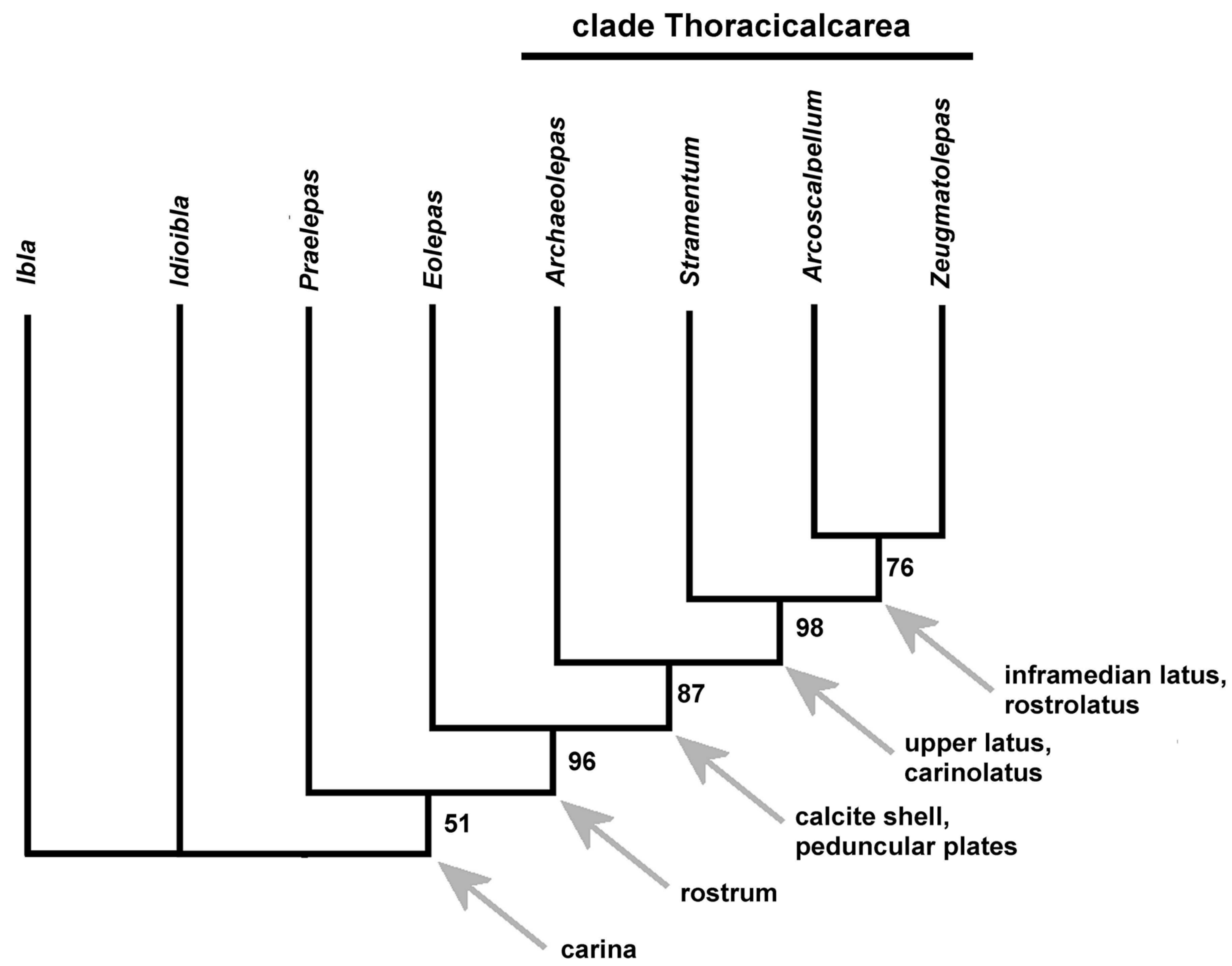




\section{Stramentidae}

Loric.

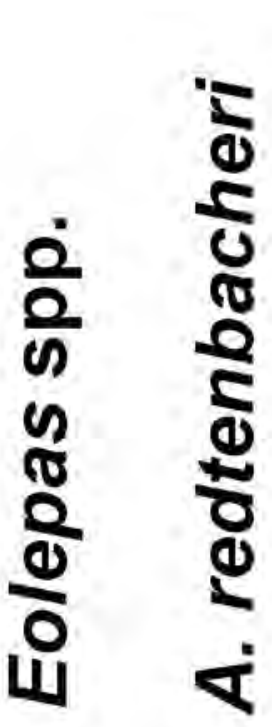

Stramentinae

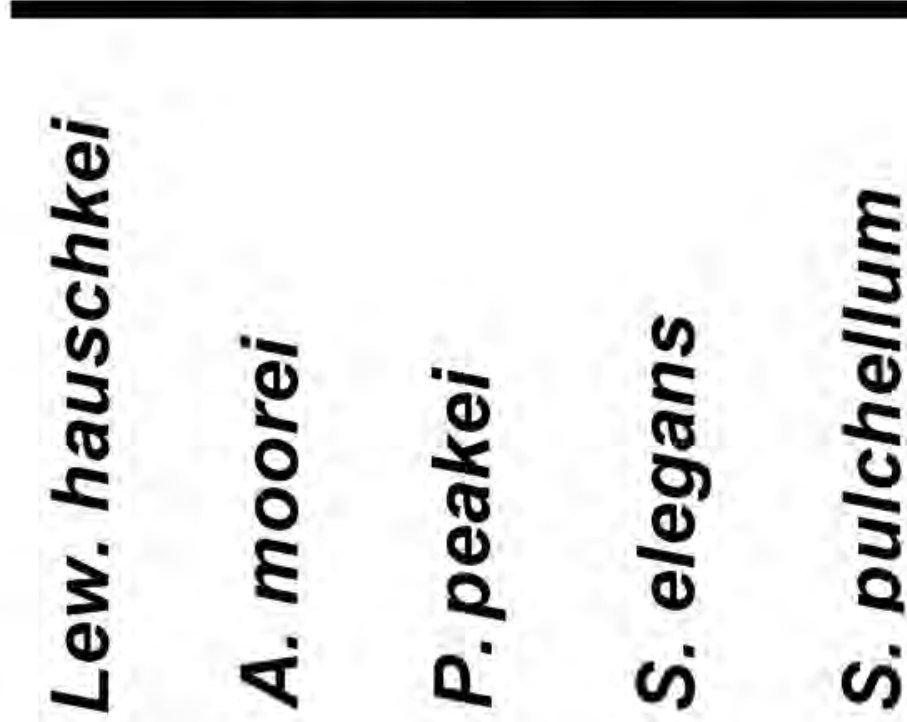

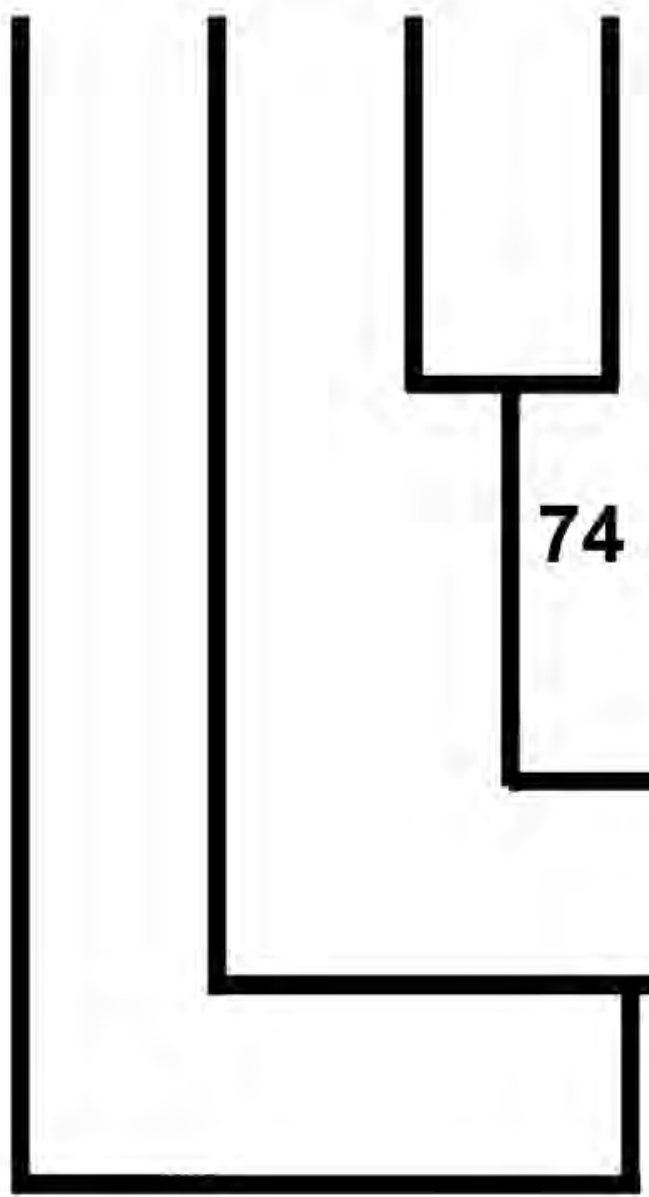

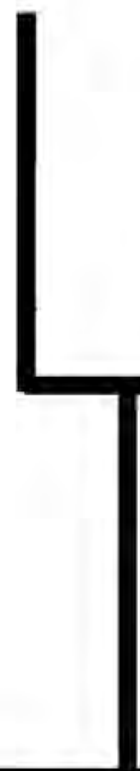

100 

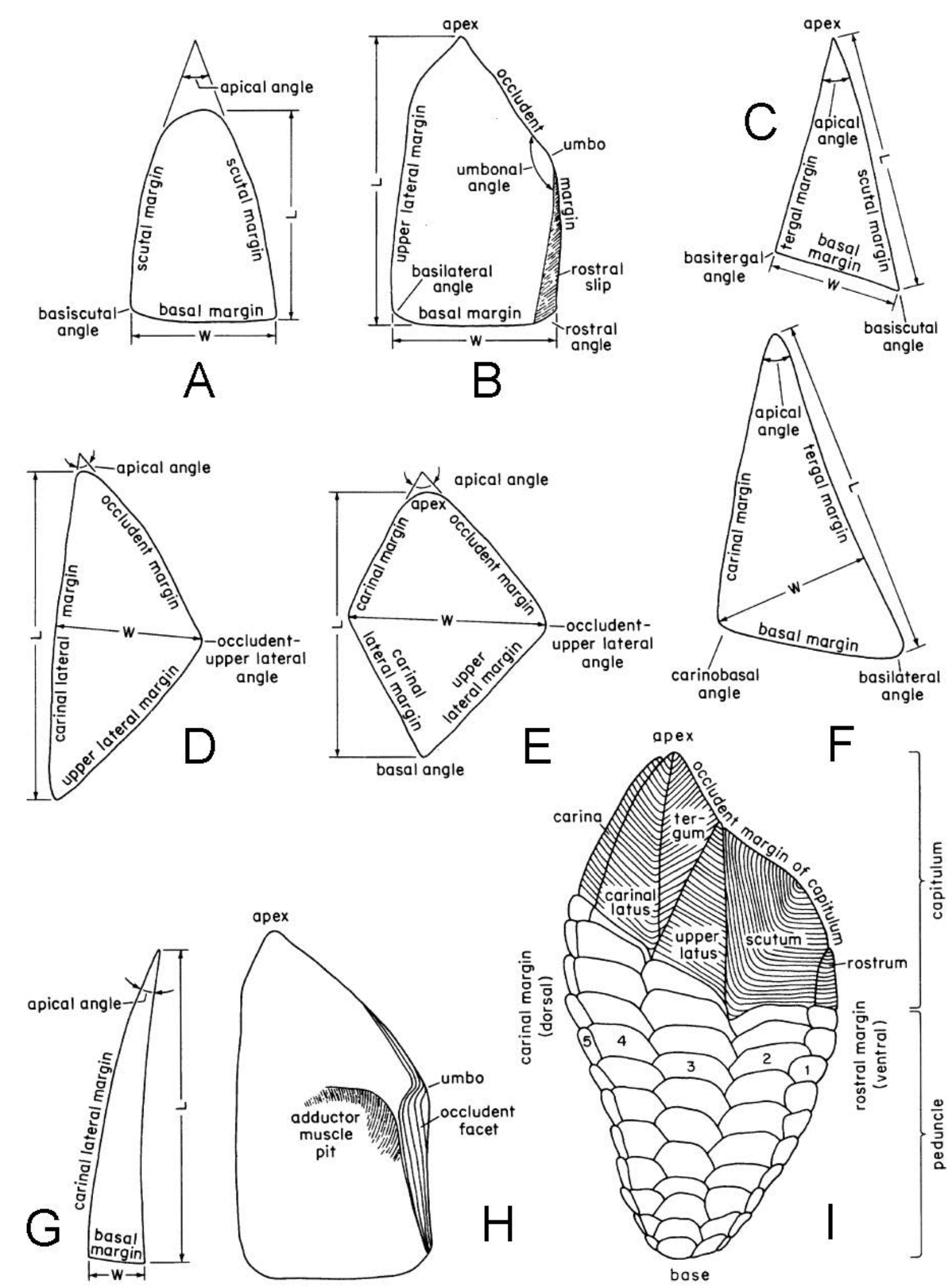

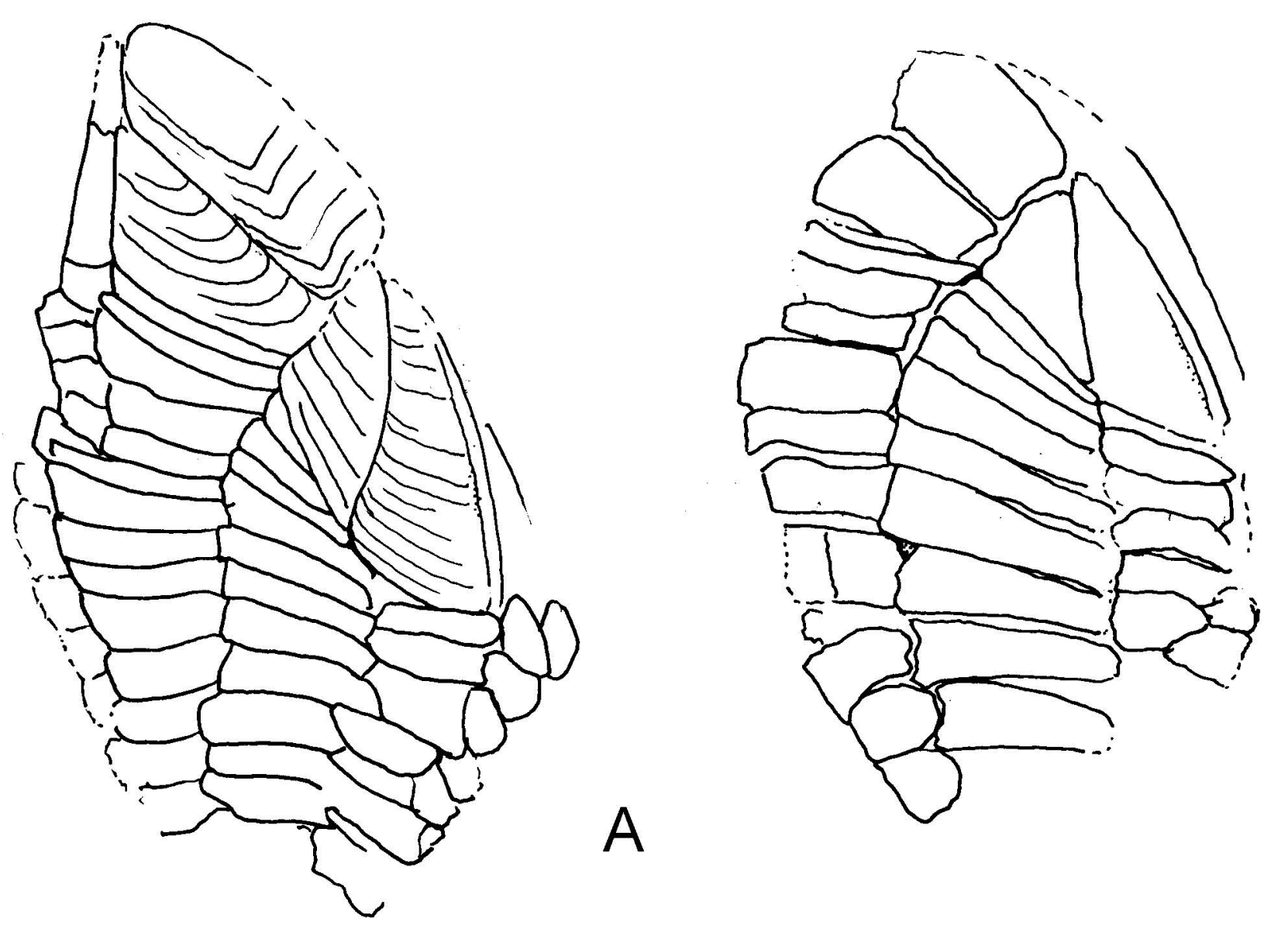

A

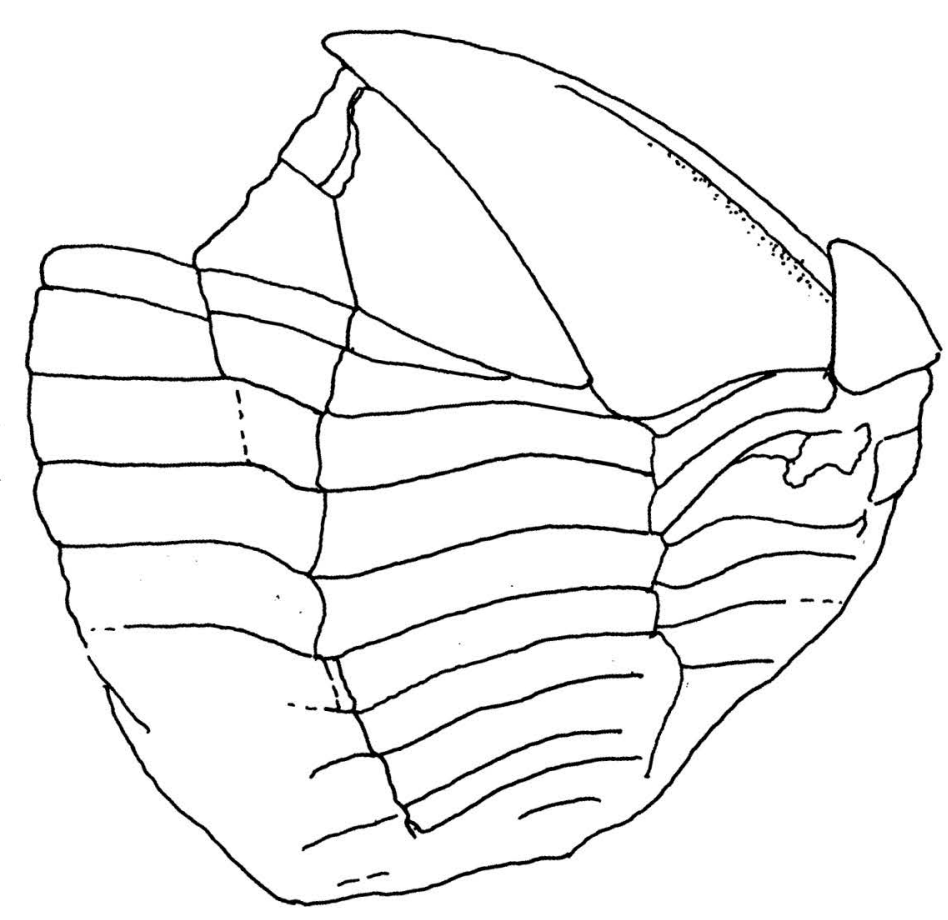

B

C
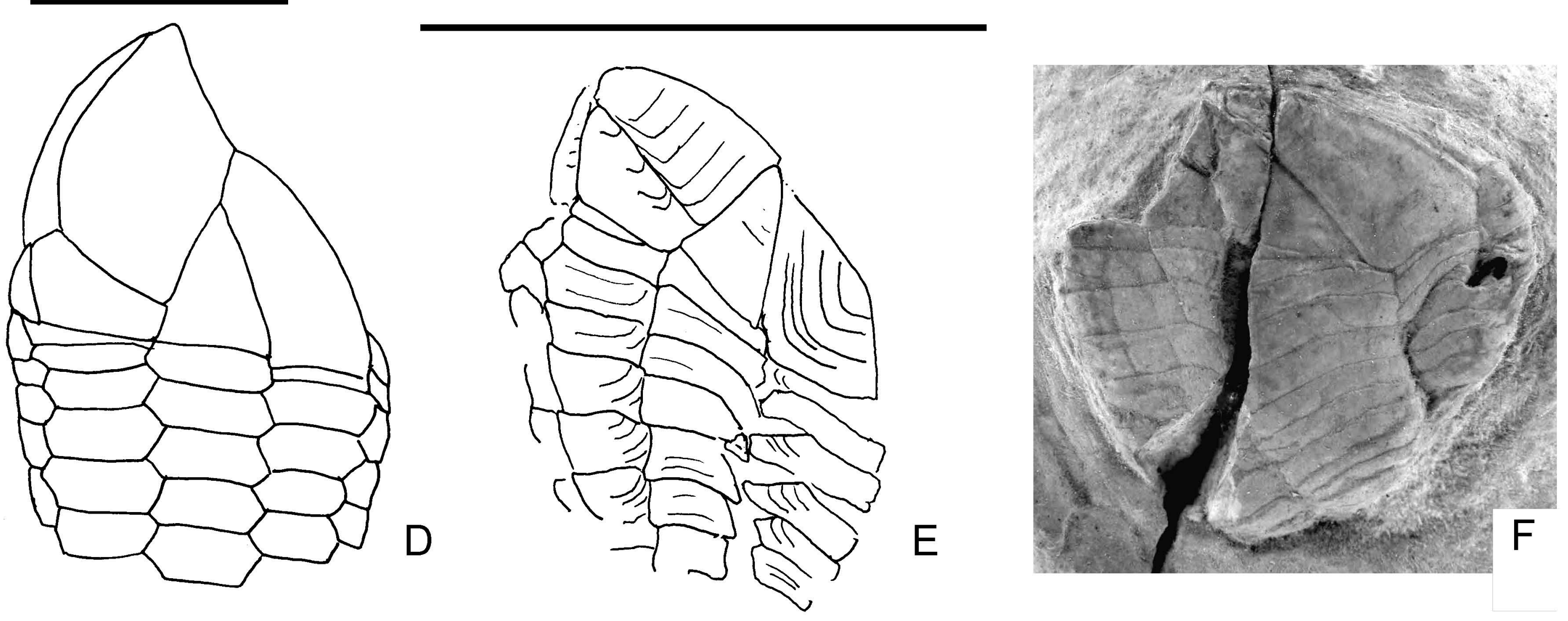


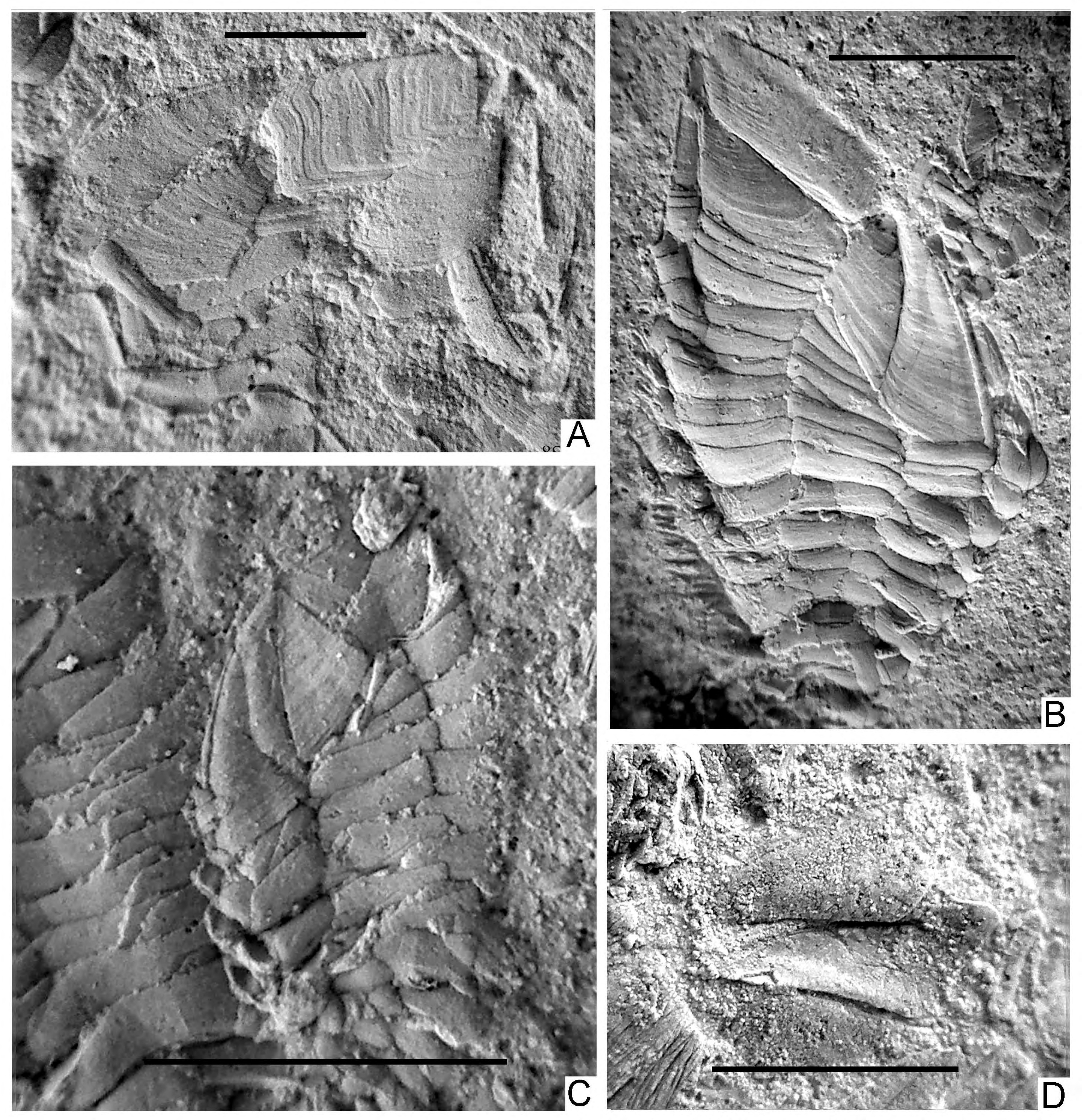



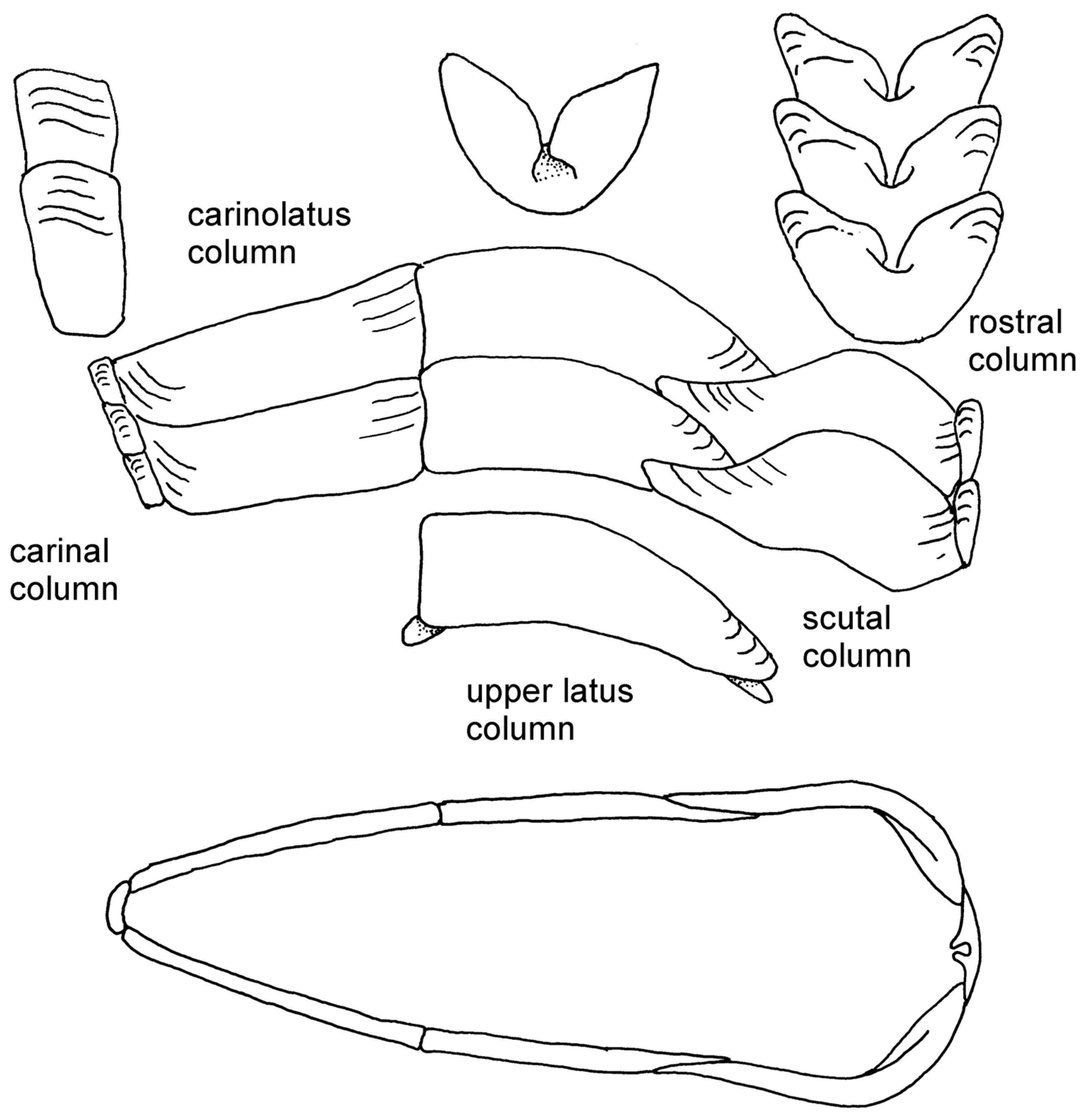


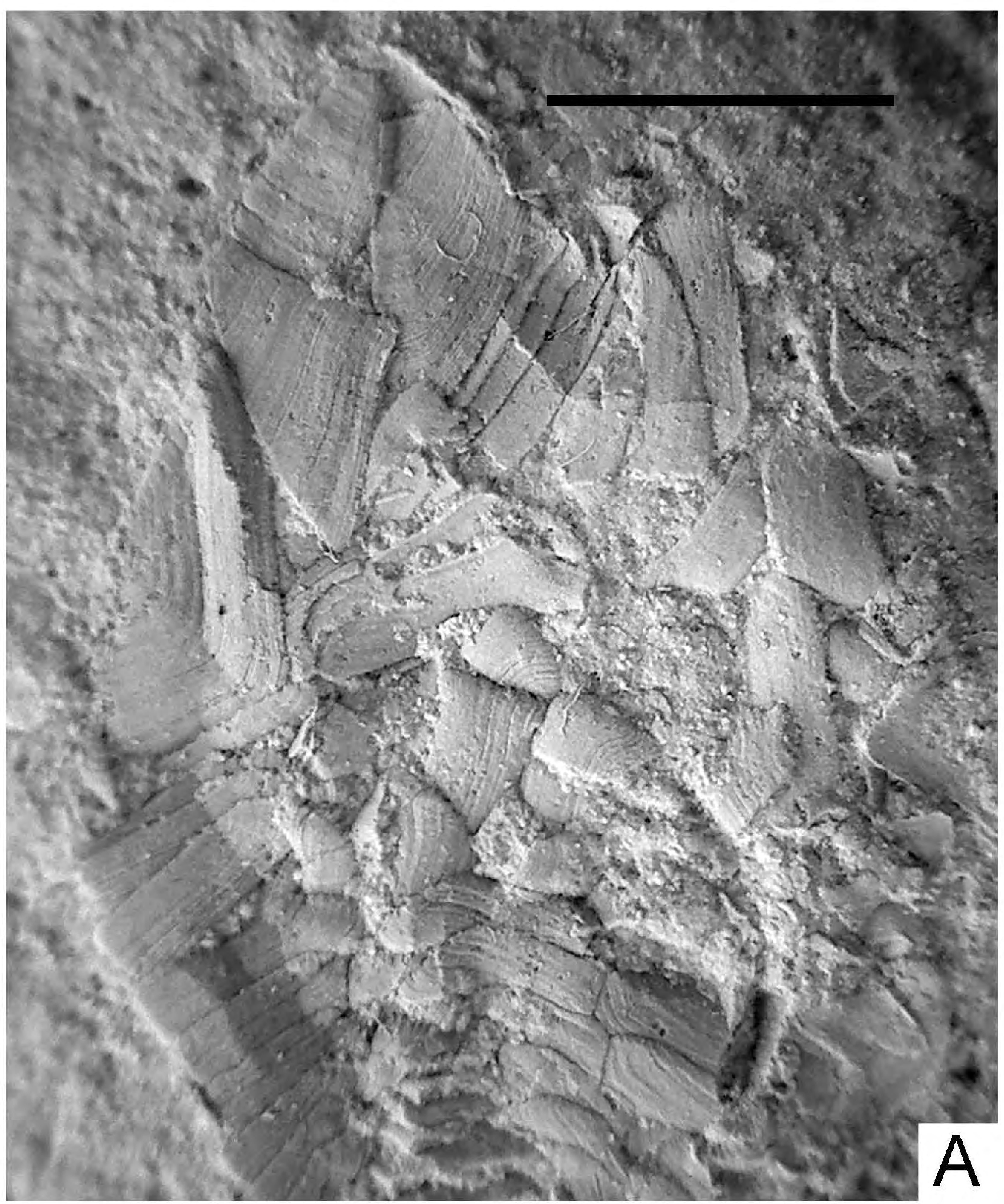

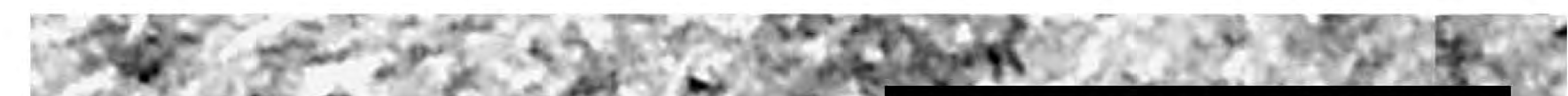

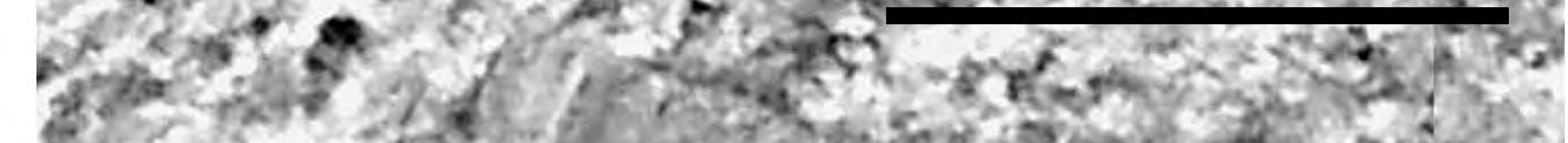

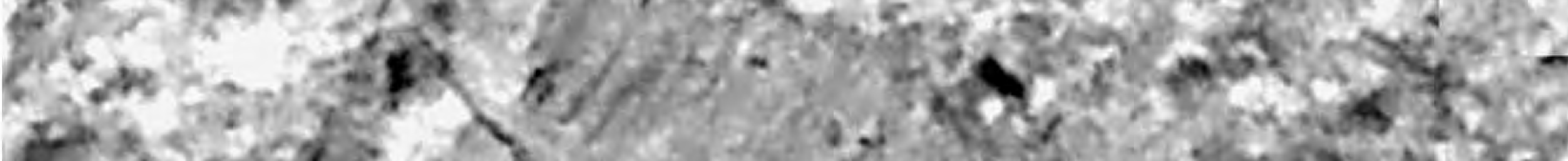

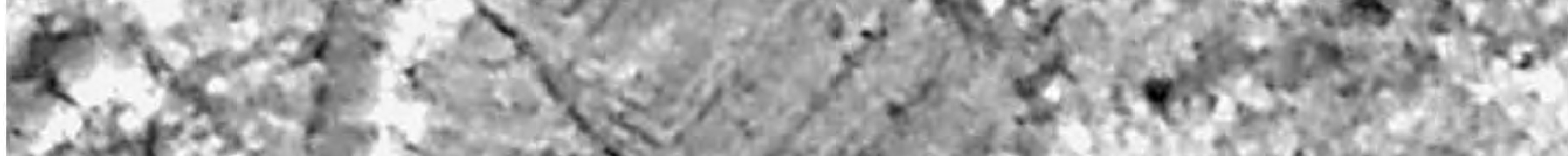

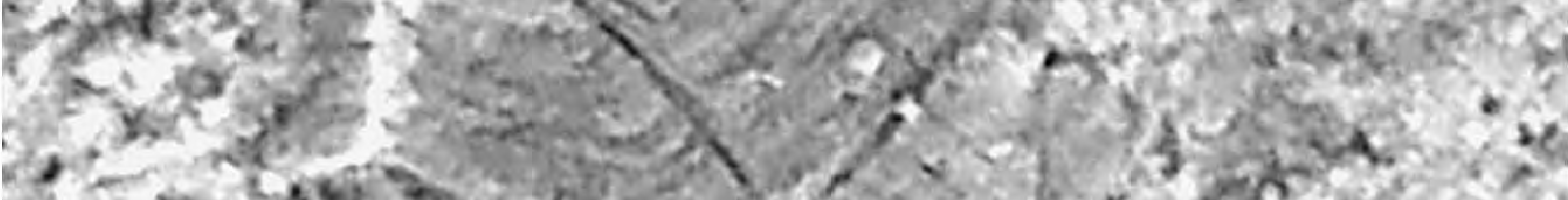
(3)

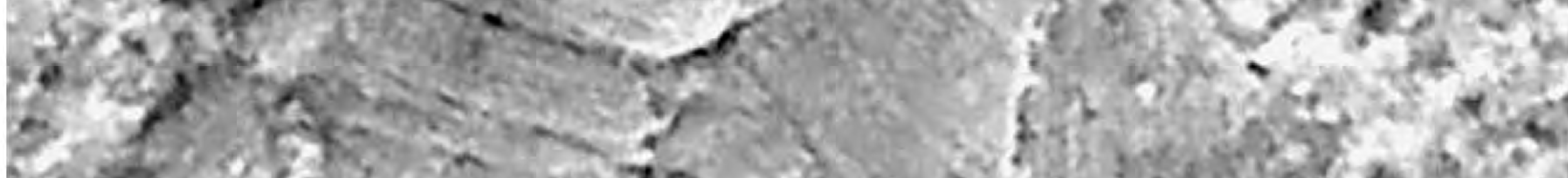

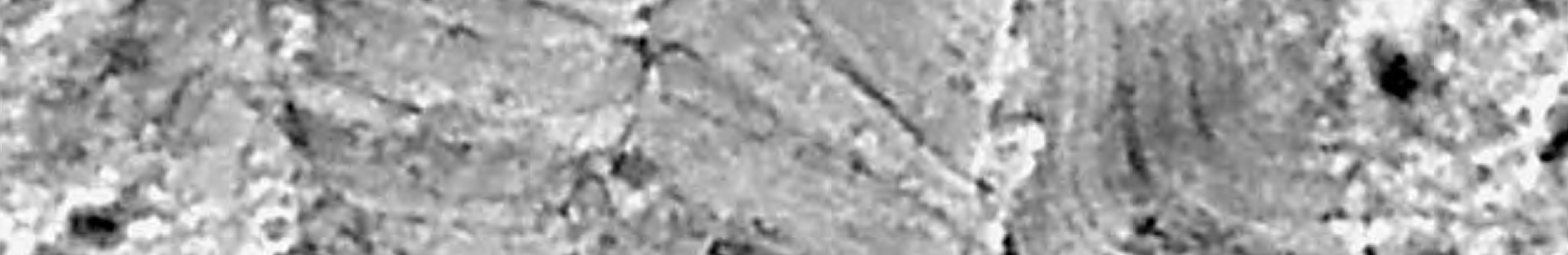

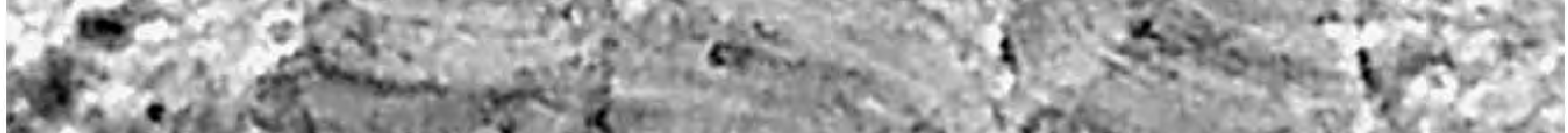

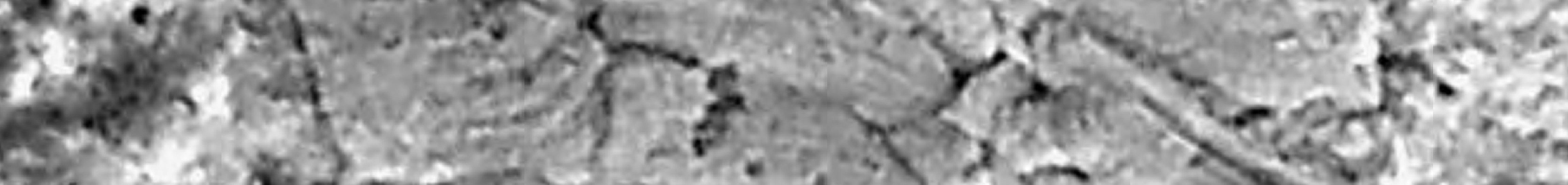

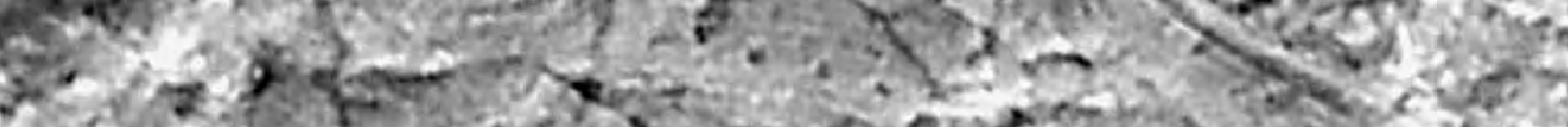

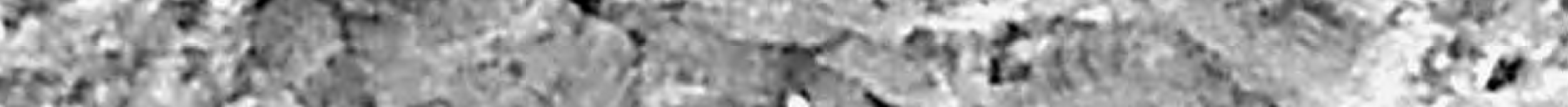
(2)

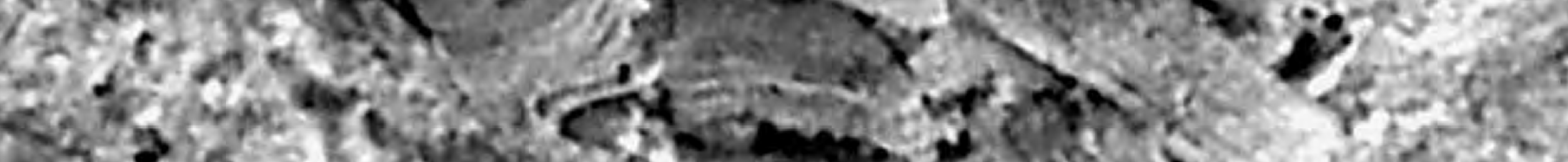

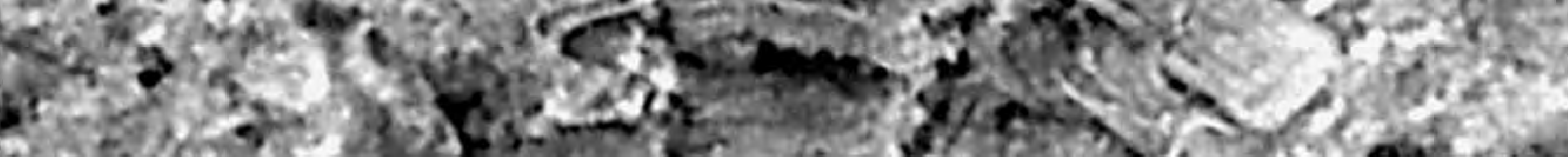

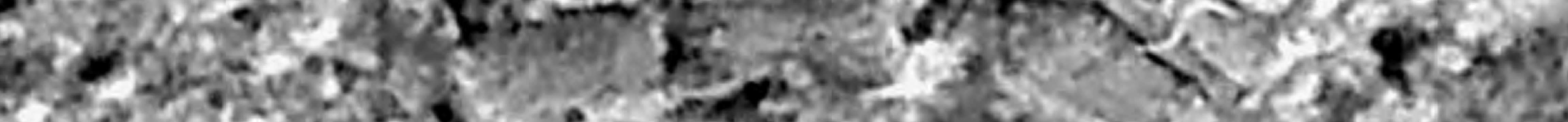

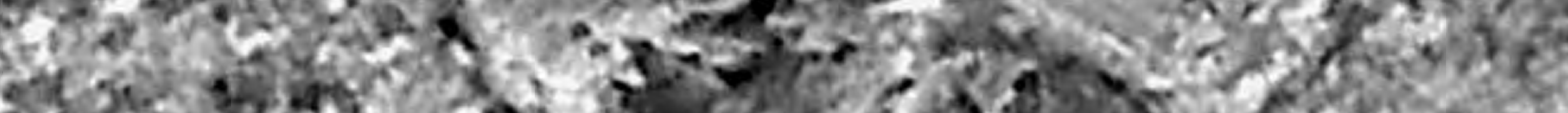

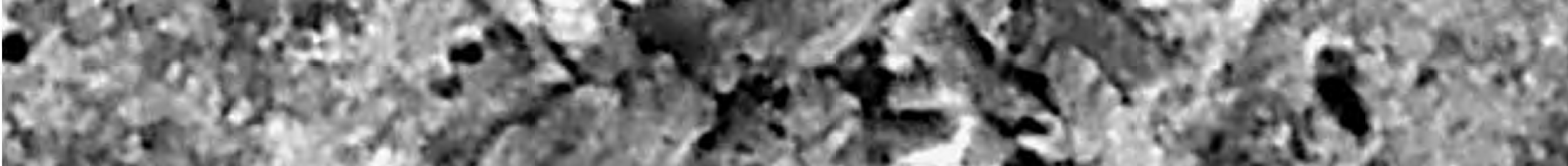

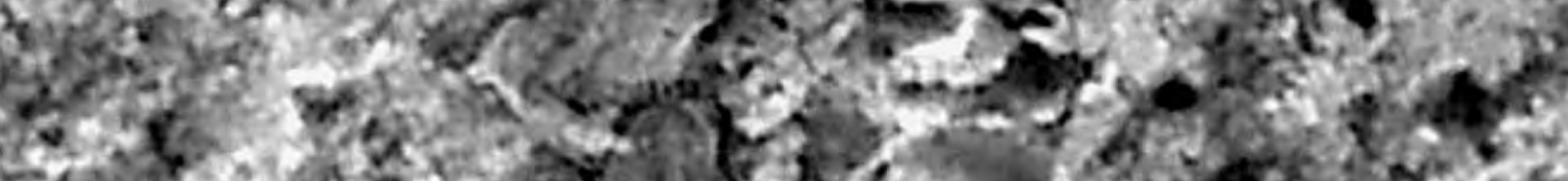

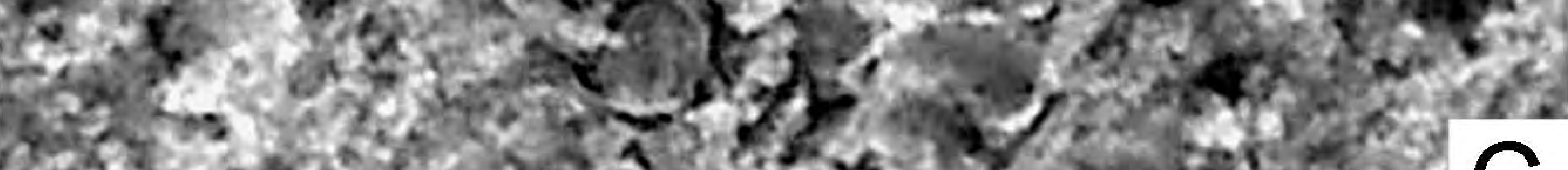

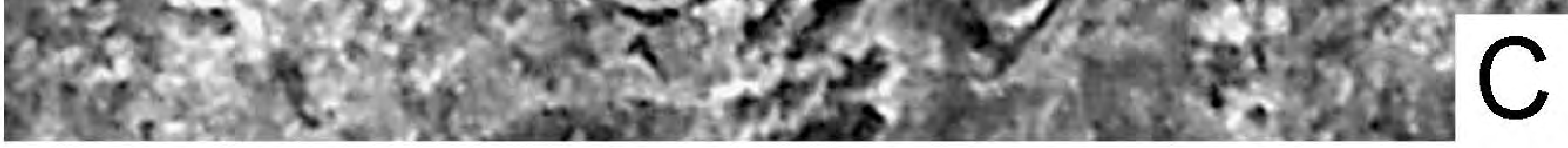
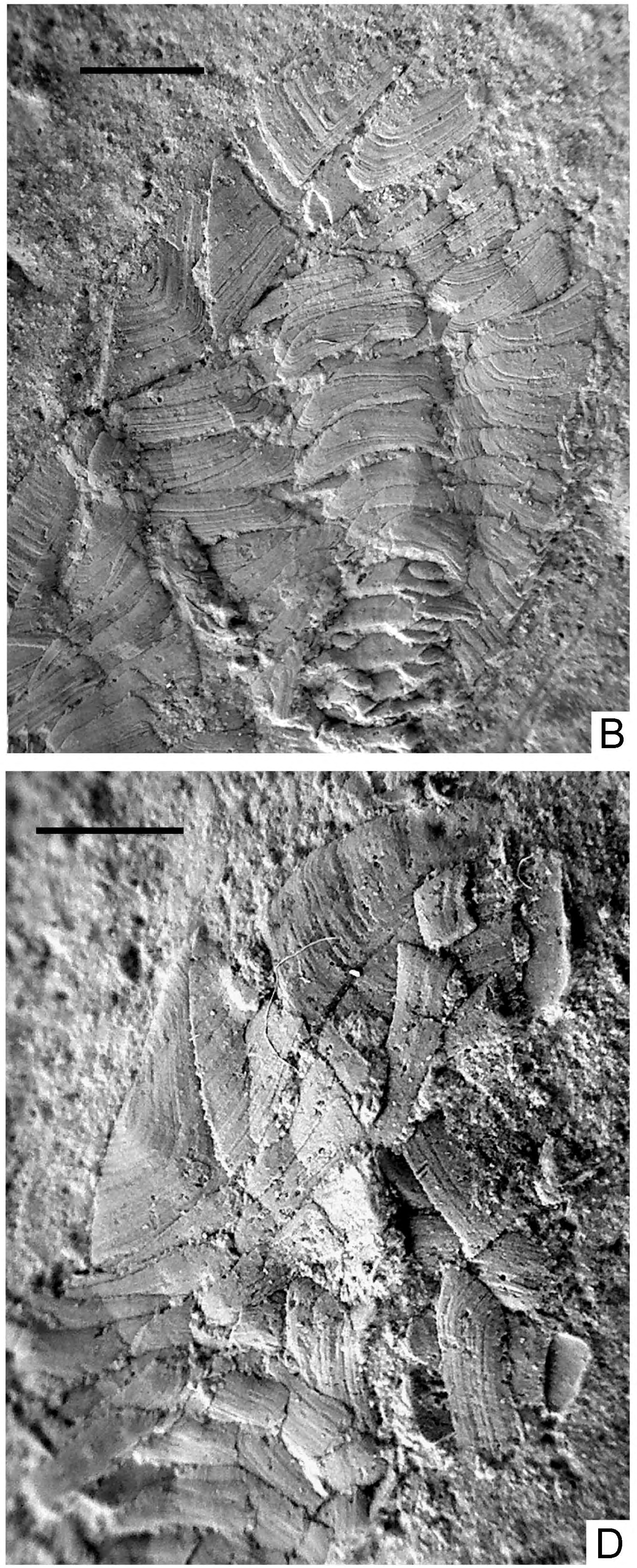


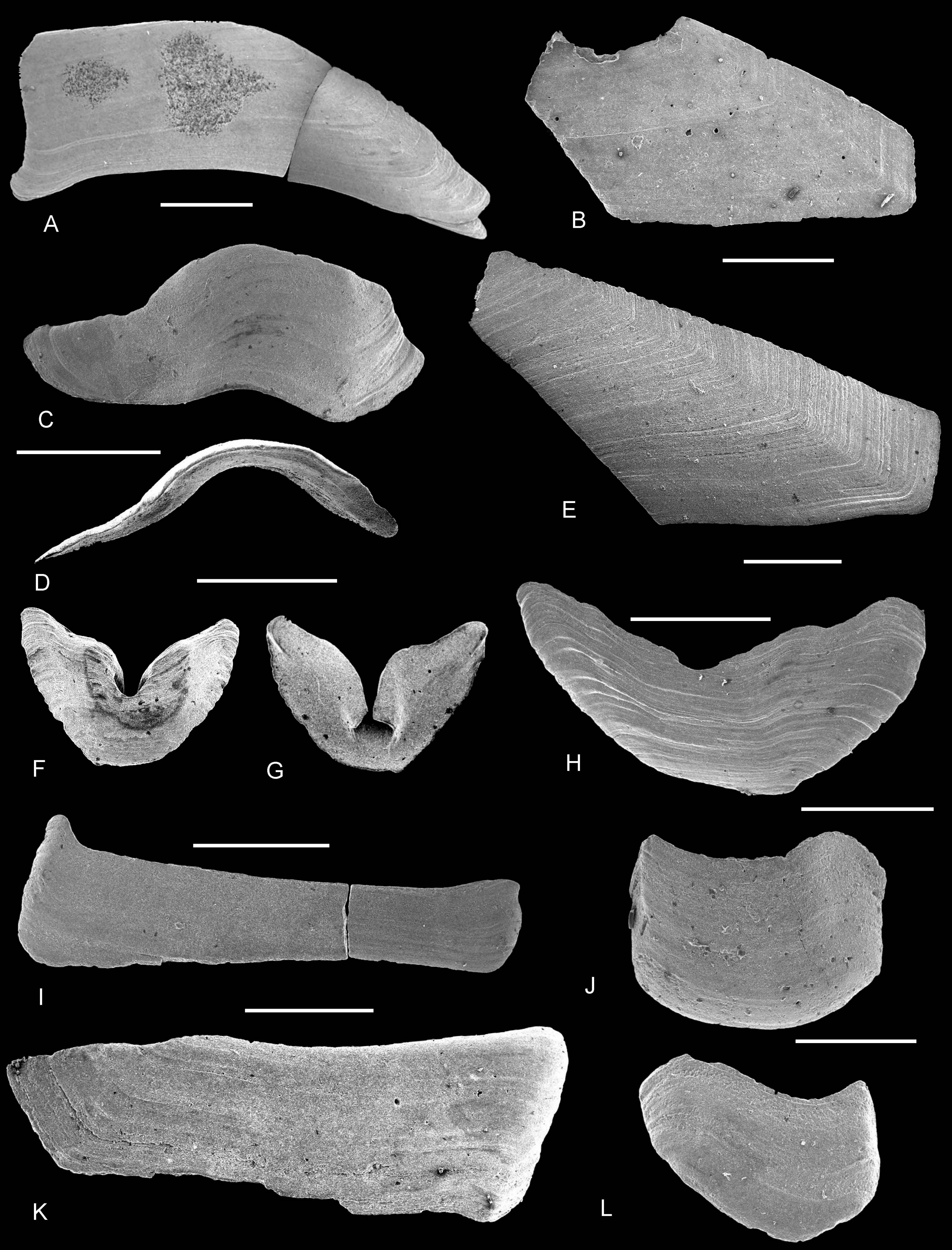



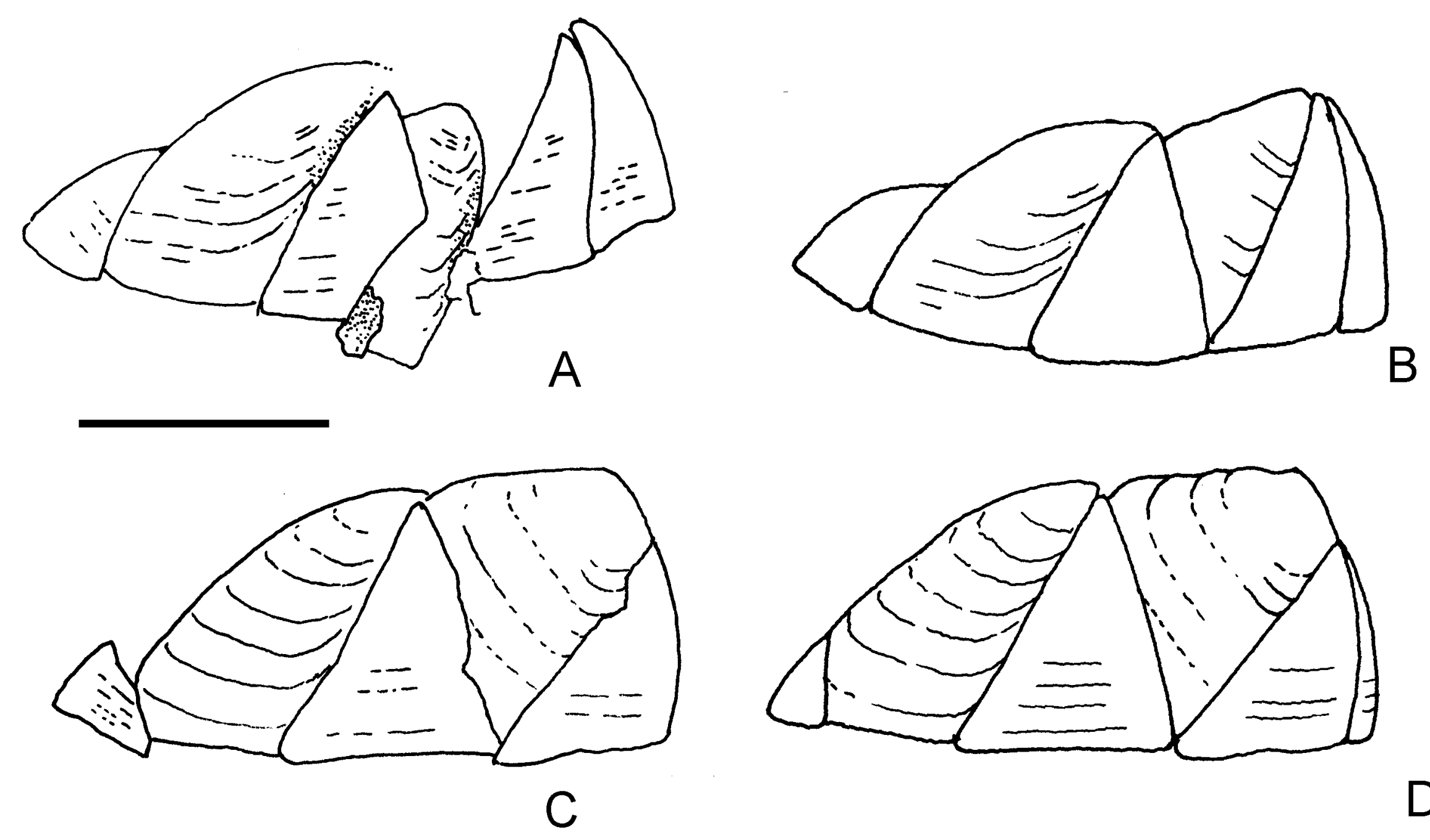

D 

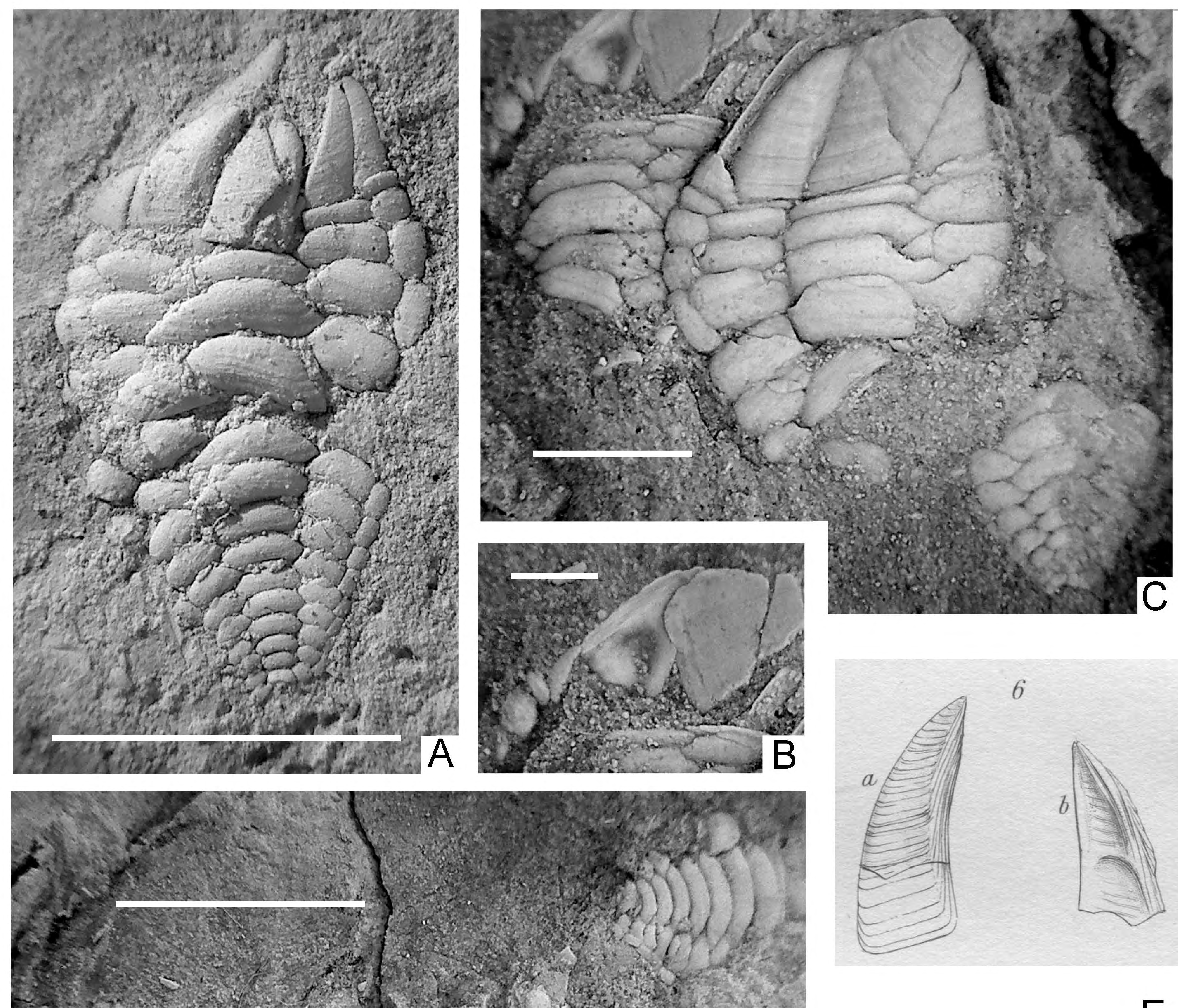

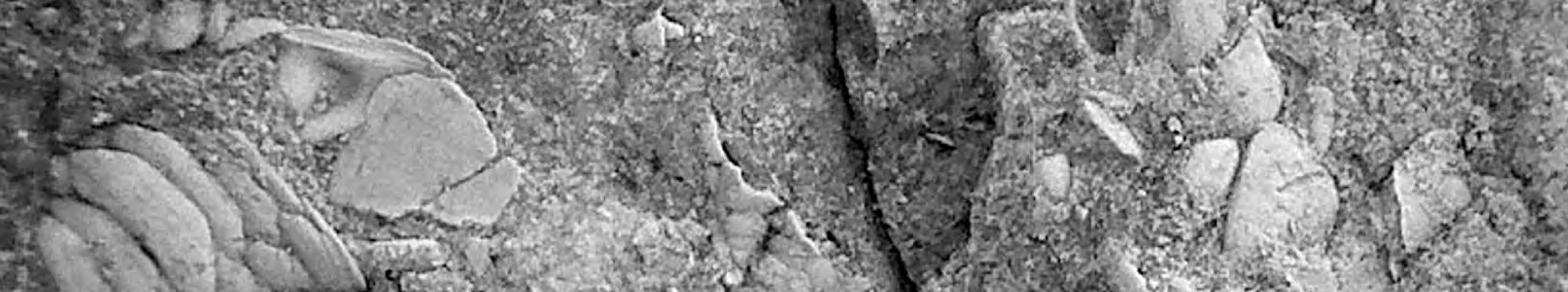



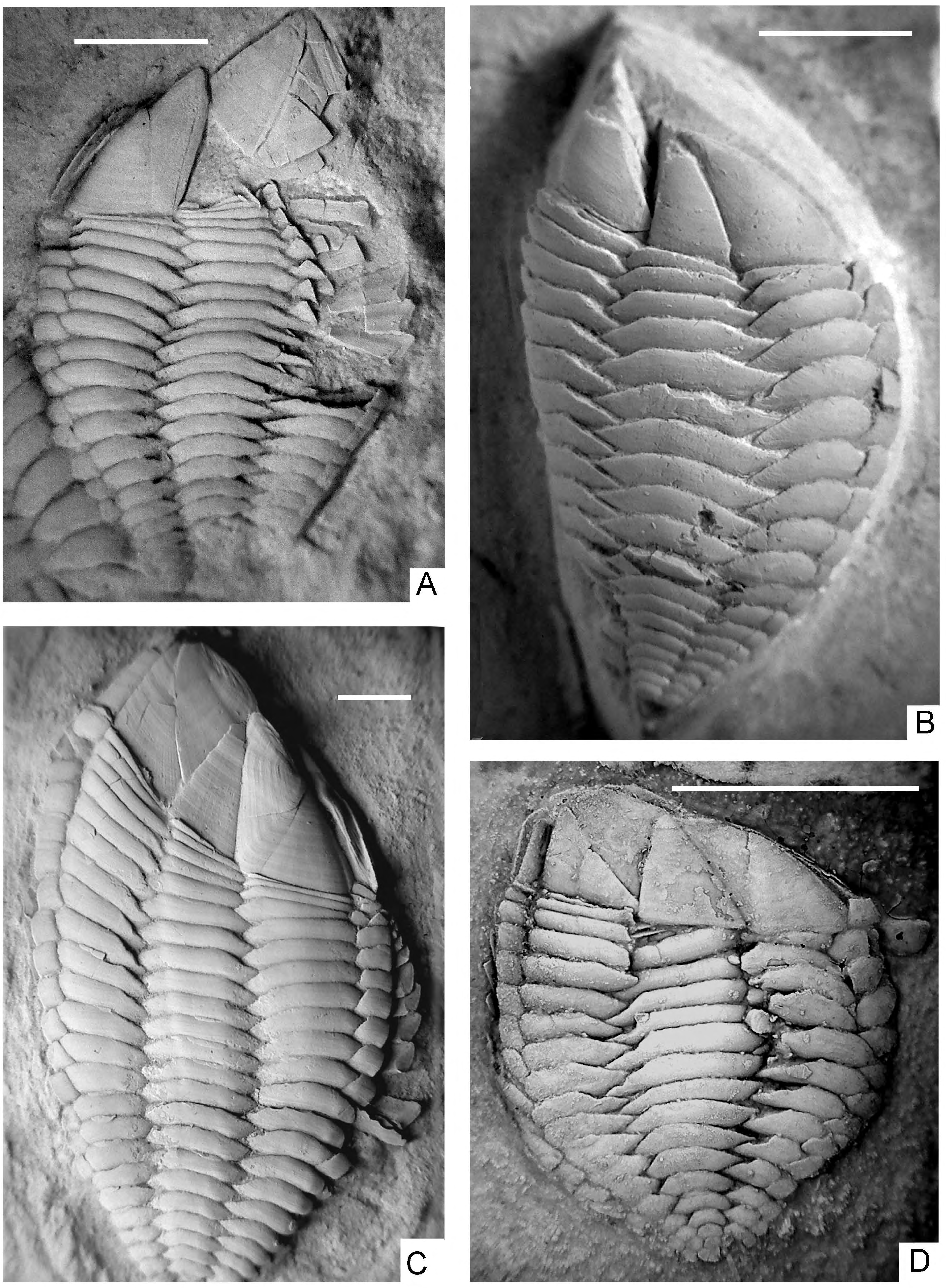



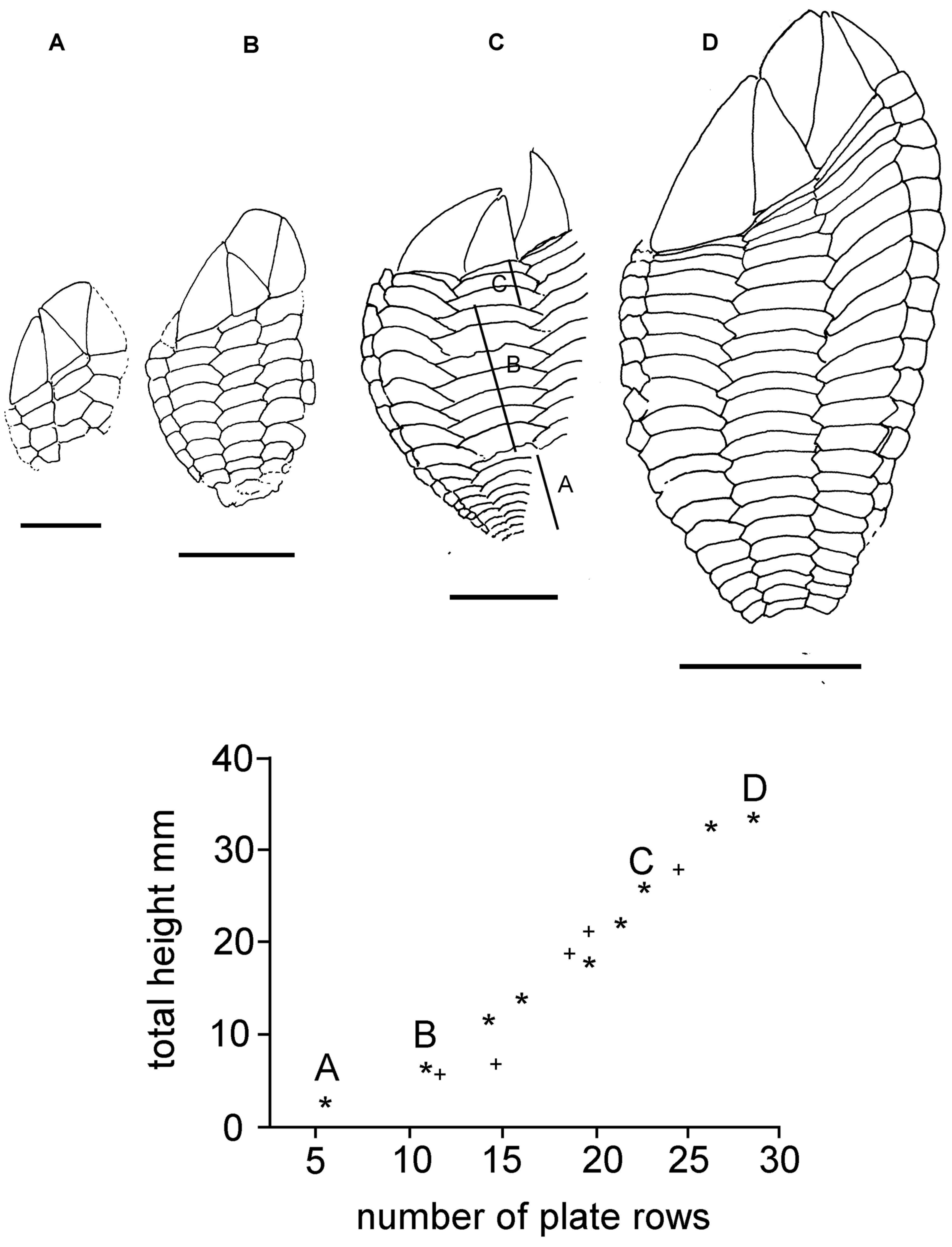


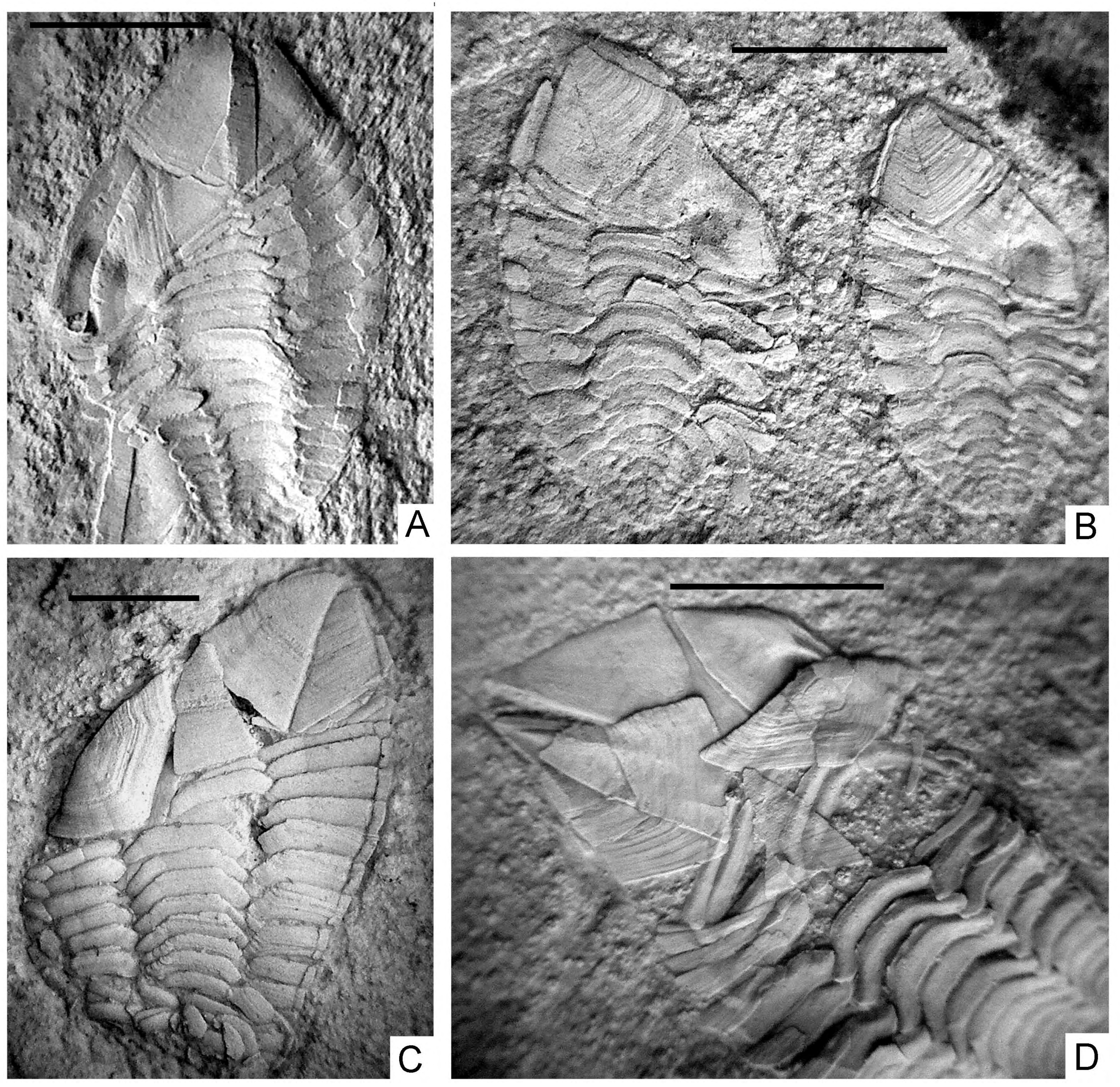




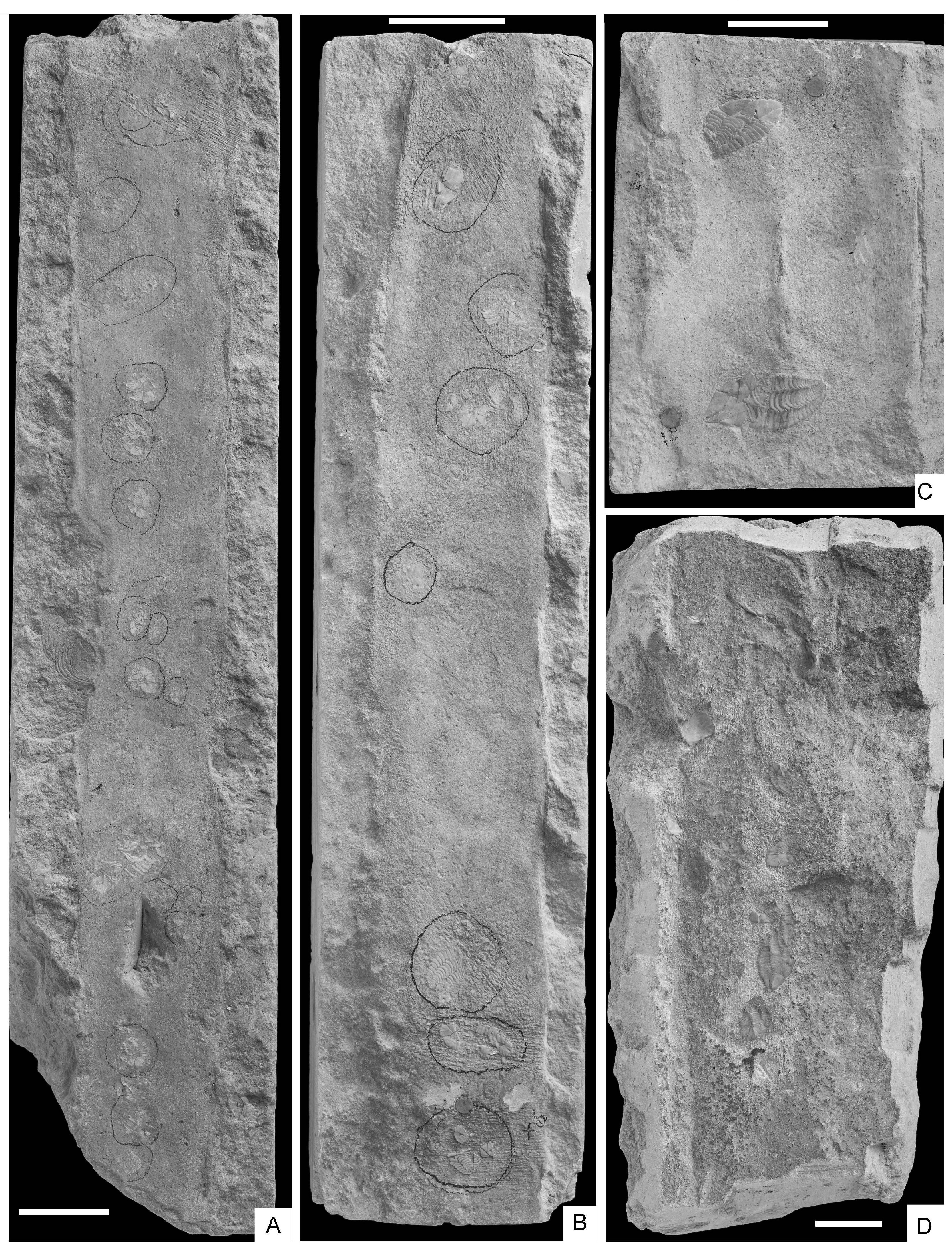









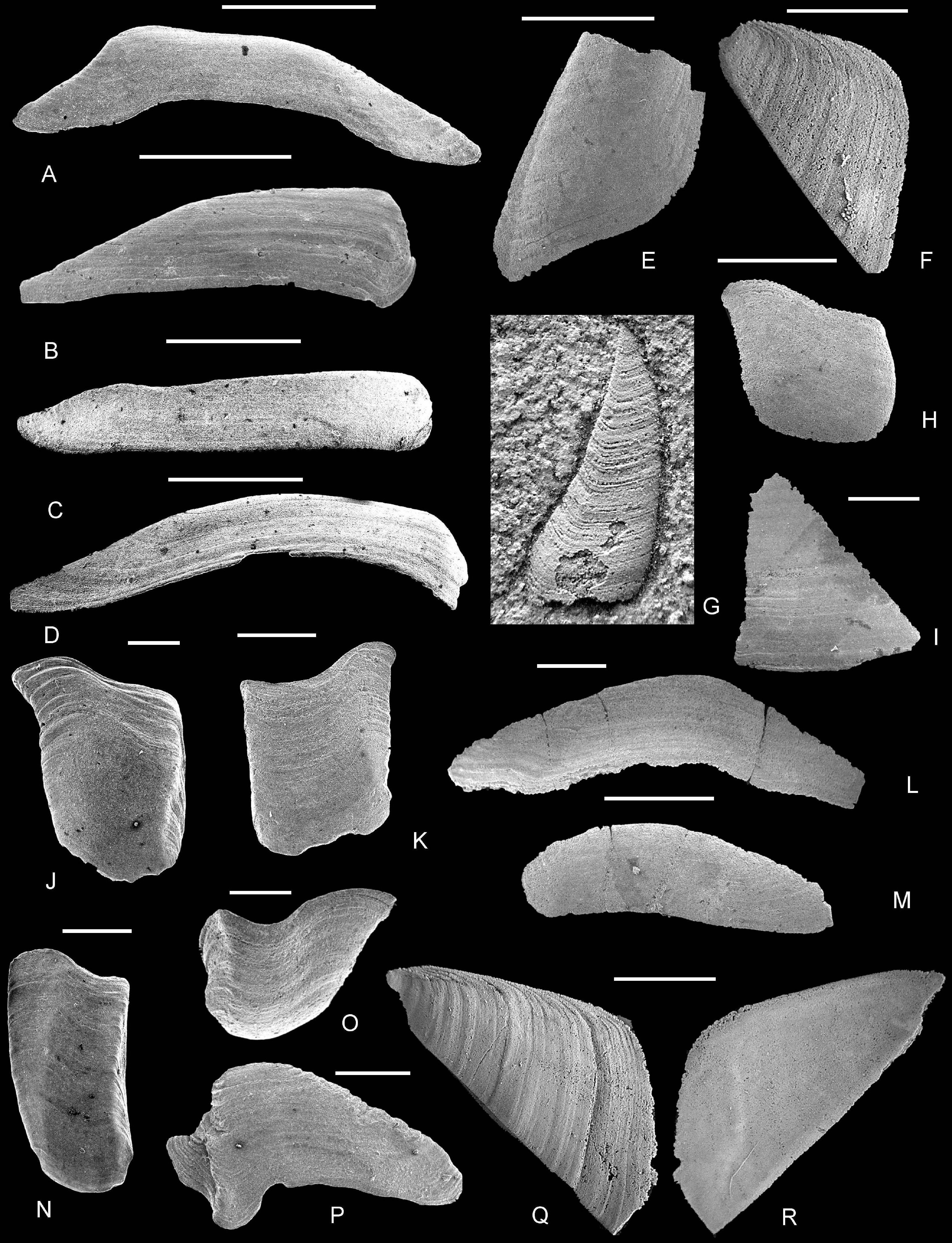




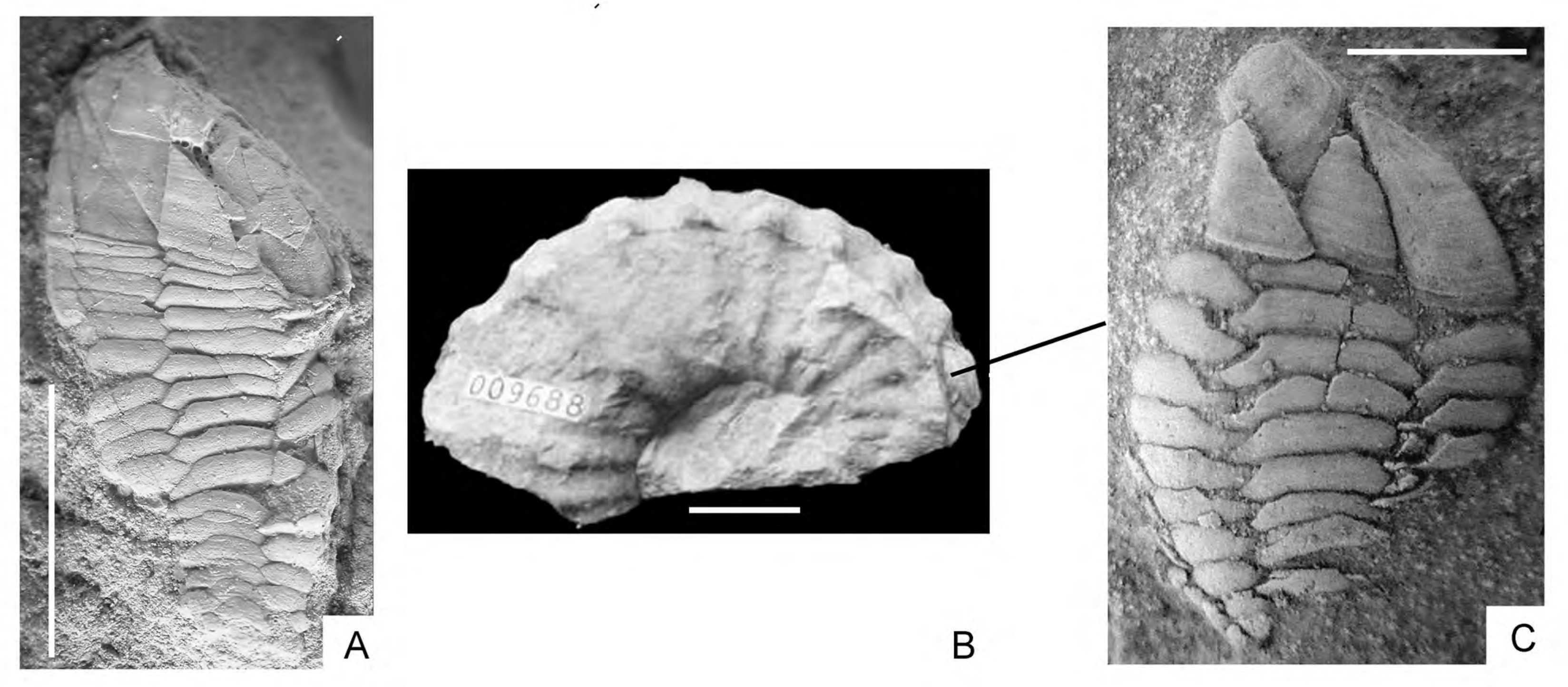




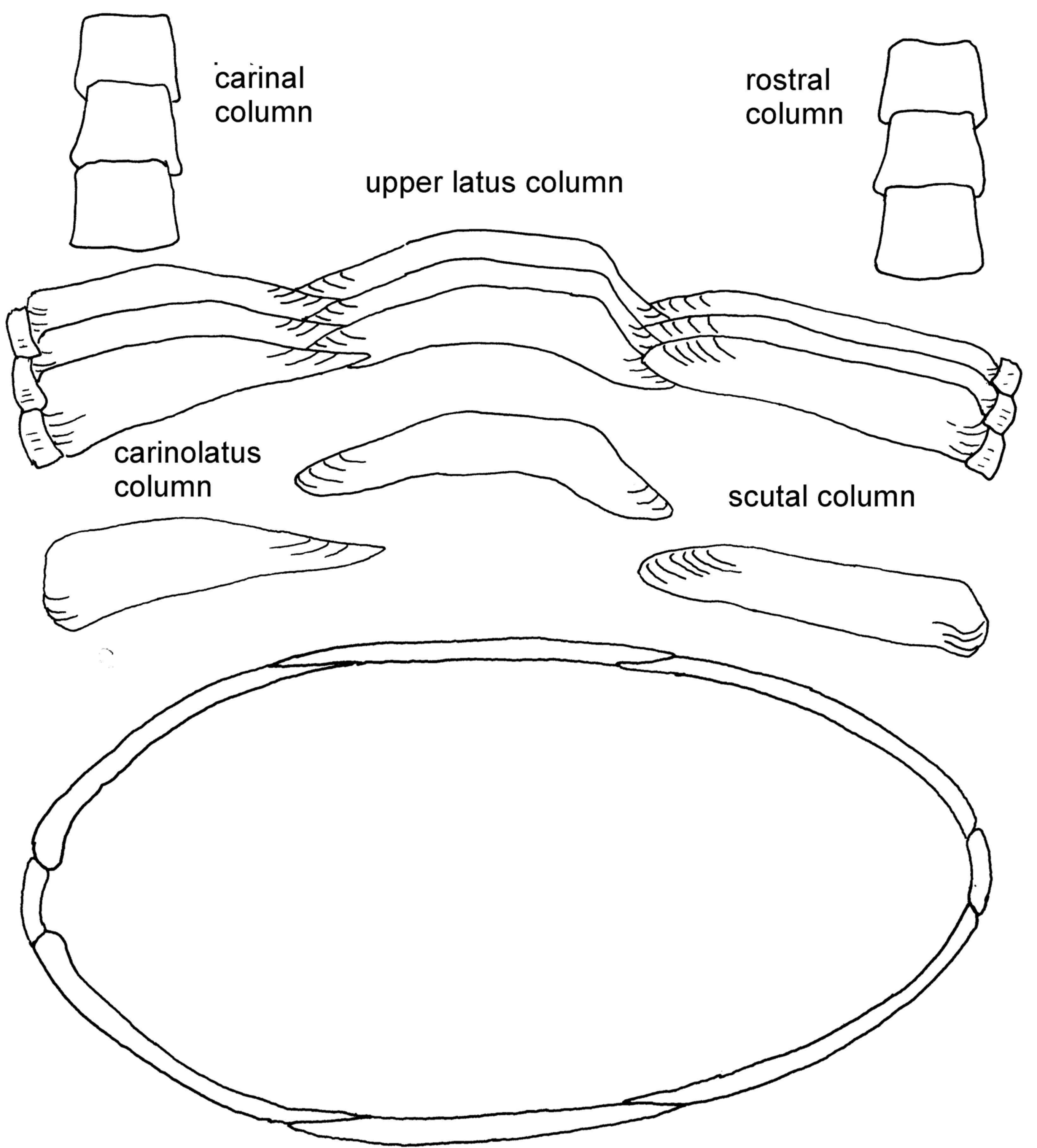


LATE TURONIAN-

CAMPANIAN

Parastramentum gen. nov.

UK and Western Interior Basin

\section{MIDDLE}

TURONIAN

Stramentum elegans

Western Interior Basin

\section{MIDDLE}

TURONIAN

Stramentum canadensis

Western Interior Basin

LATE CENOMANIAN-

\section{TURONIAN}

Stramentum pulchellum

UK, Germany Czech Republic

\section{MIDDLE}

\section{CENOMANIAN}

Stramentum praecursor sp. nov.

\section{UK}

\section{LOWER CENOMANIAN}

Leweslepas hauschkei gen. et sp. nov.
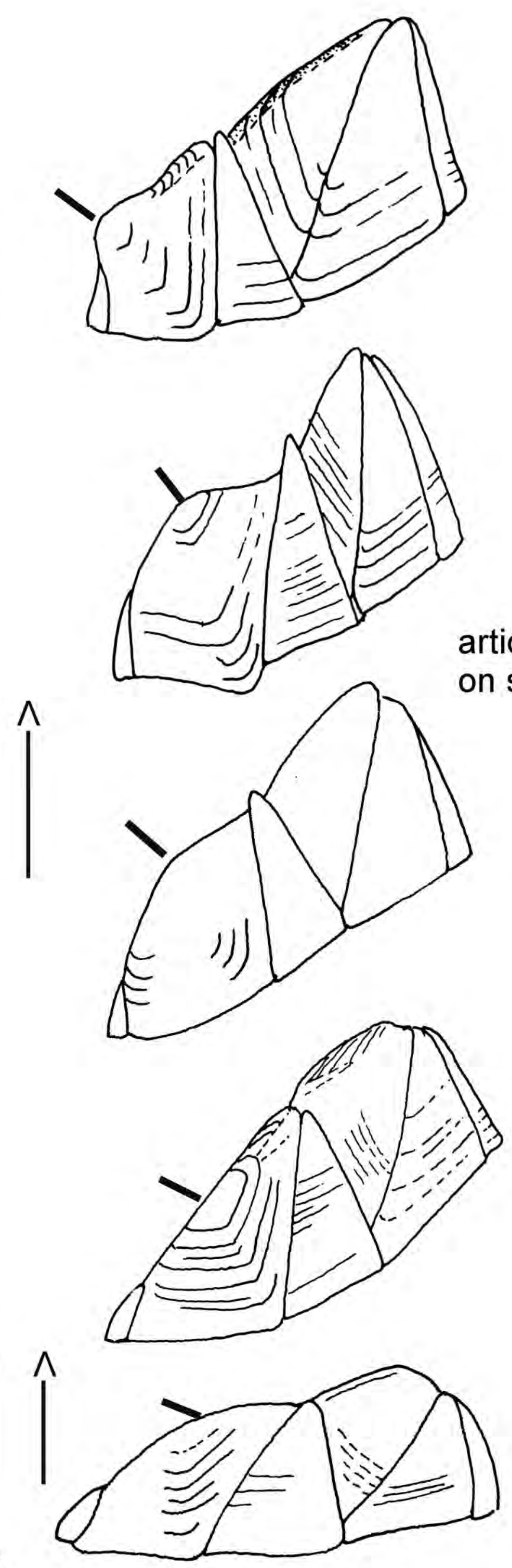

increased capitular angle

subapical scutal umbo

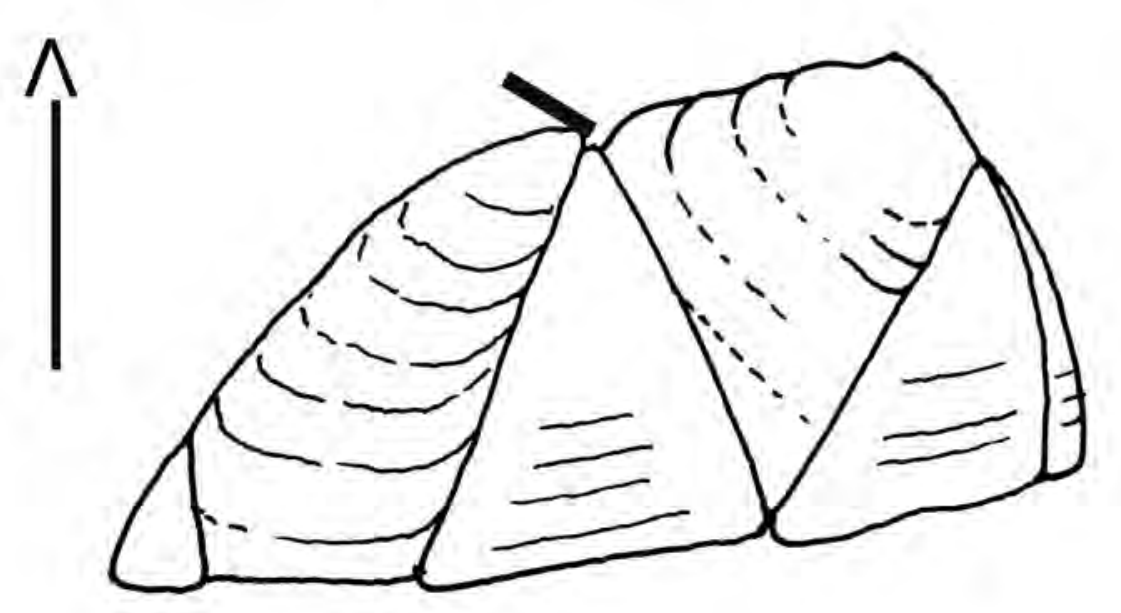

